

\section{REPUBLIC OF THE PHILIPPINES NATIONAL URBAN ASSESSMENT}


(C) 2014 Asian Development Bank

All rights reserved. Published in 2014.

Printed in the Philippines.

ISBN 978-92-9254-486-7 (Print), 978-92-9254-487-4 (e-ISBN)

Publication Stock No. RPT146356

Cataloging-in-Publication Data.

Naik Singru, Ramola and Michael Lindfield.

Republic of the Philippines National Urban Assessment. Mandaluyong City, Philippines: Asian Development Bank, 2014.

$\begin{array}{lll}\text { 1. Urban development. } & \text { 2. Philippines. } & \text { 3. National urban assessment, strategy, and road maps. }\end{array}$

I. Asian Development Bank.

The views expressed in this publication are those of the authors and do not necessarily reflect the views and policies of the Asian Development Bank (ADB) or its Board of Governors or the governments they represent.

ADB does not guarantee the accuracy of the data included in this publication and accepts no responsibility for any consequence of their use.

By making any designation of or reference to a particular territory or geographic area, or by using the term "country" in this document, $A D B$ does not intend to make any judgments as to the legal or other status of any territory or area.

ADB encourages printing or copying information exclusively for personal and noncommercial use with proper acknowledgment of $A D B$. Users are restricted from reselling, redistributing, or creating derivative works for commercial purposes without the express, written consent of ADB.

Note:

In this report, "\$” refers to US dollars.

6 ADB Avenue, Mandaluyong City

1550 Metro Manila, Philippines

Tel +6326324444

Fax +6326362444

www.adb.org

For orders, please contact:

Public Information Center

Fax +6326362584

adbpub@adb.org

Printed on recycled paper 


\section{Contents}

Figures, Charts, Tables, and Maps iv

Acknowledgments

Abstract vii

Currency Equivalents $\quad$ vii

Abbreviations viii

1 Introduction 1

2 Country Profile 2

Location 2

Political History 3

Political System 4

Urbanization Profile 5

$\begin{array}{lr}\text { Governance and Urban Management Profile } & 15\end{array}$

Institutional Structures for Urban Development 15

Key Urban Development Framework 16

Key Urban Development Legislation $\quad 19$

Urban Finance Matrix $\quad 21$

$\begin{array}{ll}\text { Legislative and Regulatory Framework } & 24\end{array}$

Enabling Environment $\quad 24$

Competitive Base: Economic Profile $\quad 30$

Inclusive Base: Equity Profile $\quad 35$

Green Base: Environmental Profile $\quad 38$

ADB and Development Partner Support in Urban Development 42

Capacity Development Needs Assessment $\quad 50$

3 Urban Needs Assessment 56

Sector-Based Needs Assessment $\quad 56$

4 Urban Strategy and Prioritization $\quad 67$

$\begin{array}{ll}\text { National Strategy } & 67\end{array}$

$\begin{array}{ll}\text { Urban Sector Strategy } & 67\end{array}$

ADB-Philippines Country Partnership Strategy 68

5 Urban Priorities $\quad 69$

6 Policy and Programming $\quad 72$

$\begin{array}{ll}\text { Strategic Urban Infrastructure Investment Plan } & 72\end{array}$

$7 \quad 3 E$ Targeted Investment Program $\quad 75$

Urban Projects Formulated Based on 3E Assessment $\quad 75$

$\begin{array}{ll}\text { Appendix } & 78\end{array}$

$\begin{array}{ll}\text { References } & 81\end{array}$ 


\section{Figures, Charts, Tables, and Maps}

Figures

1 Integrated Sustainable Urban Development Framework 1

2 Urban and Rural Population, 1990-2010 5

3 Total Population Change 6

4 Total, Urban, and Rural Population, 1995-2010 6

5 Annual Growth Rate of Urban Population by Region, 1975-2000 7

6 Population Density (persons $/ \mathrm{km}^{2}$ ) vs. Land Area by Region, 2010

7 Urbanization by Region, 2000

8 Population Density and Area of Metropolitan Regions, Philippines, 2007

9 Ten Most Populous Cities in the Philippines, 1990-2007 12

10 Net International Migration Rate, Philippines, 1990-2010 13

11 Land Classification, $2009 \quad 14$

\section{Charts}

1 Institutional Structure for Delivering Urban Development 17

2 Functional Areas and Responsibilities for Urban Services 18

3 Philippines Urban Planning Framework: Tiers and Linkages 19

4 Urban Finance Matrix 21

5 Revenue Collections by Region, 2004-2009 22

6 Sources and Types of Income of Local Government Units 23

7 Internal Revenue Allotments by Region, 2005-2010 24

8 Ease of Starting a Business in the Philippines 28

9 Global Competitive Index 28

10 Most Problematic Factors for Doing Business in Philippine Cities 29

11 Ease of Dealing with Construction Permits in Philippine Cities 30

12 Ease of Registering Property in Philippine Cities 31

13 Foreign Direct Investments by Region, 1990-2010 32

14 Gross Domestic Product by Region, 1995-2009 33

15 International Tourism Performance 34

16 Intra-Urban Inequalities-Gini Coefficient 35

17 Unemployment Rate, 1995-2010 36

18 Urban Slum Population 37

19 Greenhouse Gas Emissions 41

20 Carbon Dioxide Emissions in Transport and Power Sectors 42

21 Total Number of Graduates by Degree Program, 1999-2012 52

22 Use of Sanitation Facilities, 1990-2008 60

23 Status of Energization by Region, 200964

24 Electricity Generation and Consumption 64

25 Average Retail Electricity Tariffs $\quad 65$ 


\section{Tables}

1 Projected Levels of Urbanization

2 Suggested Areas for Interventions along the 3E Approach of ADB Urban Operational Plan

3 3E Targeted Investment Priorities by Sector $\quad 75$

A1 Indicative Investment Requirements of Basic Urban Services by Region 78

A2 Indicative Investment Requirements of the Basic Urban Services by Sector $\quad 79$

A3 Proposed Financing Plan

\section{Maps}

1 Administrative Regions of the Philippines

2 Urban Settlements in the Philippines, $2010 \quad 11$

3 Cities Exposed to Multi-Hazards 39

4 National Spatial Strategy and Priorities $\quad 71$ 


\section{Acknowledgments}

W

e gratefully acknowledge the discussions and input of our colleagues. The authors would like to thank WooChong Um, The Secretary of the Asian Development Bank; Gil-Hong Kim, director, Sustainable Infrastructure Division, RSDD; Ramesh Subramaniam, deputy director general, Southeast Asia Regional Department SERD; Amy Leung, director, Southeast Asia Urban Development and Water DivisionSoutheast Asia Regional Department (SEUW-SERD); Anand Chiplunkar, director, Central and West Asia Urban Development and Water Division-Central and West Asia Regional Department (CWUW-CWRD); and Fei Yue, director, South Asia Urban Development and Water Division-South Asia Regional Department (SAUW-SARD), for their valuable inputs. We appreciate the discussions with our colleagues Tatiana Gallego-Lizon, Vijay Padmanabhan, Priyanka Sood, Claudia Buentjen, Rudolf Frauendorfer, Sonia Chand Sandhu, Florian Steinberg, Joanna Masic, and others from the urban divisions. We thank the working group on Urban Governance, Planning, and Public Financial Management of the Urban Community of Practice; Arghya Roy Sinha for his input on Disaster Risk Management; and Sonomi Tanaka and Imrana Jalal of the Gender and Development Community of Practice for peer review. Editing was done by the Department of External Relations Publishing Team. Virginia Herrera assisted on administrative matters; Vince Docta assisted with statistical data and graphs; and Rodel Bautista assisted with production matters. Vergel Latay assisted with editorial matters and provided overall coordination of production and publication.

\section{Michael Lindfield}

Lead Urban Development Specialist, and Chair of the Urban Community of Practice (CoP) (Retired)

Regional and Sustainable Development Department

\section{Ramola Naik Singru}

Senior Urban Development Specialist (Consultant)

Regional and Sustainable Development Department 


\title{
Abstract
}

\begin{abstract}
- he Asian Development Bank (ADB) under its Urban Operational Plan will support developing member countries (DMCs) in developing their urban economies, in improving environmental sustainability, and in making pro-poor investments. This provides a critical opportunity for the urban sector to potentially play an integrative role, providing a way to focus $A D B$ operations beyond traditional urban investment sectors to maximize impact. The Manual on National Urban Assessments provides a framework and toolbox for conducting rapid urban sustainability assessments at both national and urban region levels for DMCs of $A D B$. This case study on the Philippines is based on the National Urban Assessments framework for developing strategic policy options and targeted investments in the urban sector.
\end{abstract}

\section{Currency Equivalents}

(as of 1 September 2012)

Currency Unit - peso (P)

$\mathrm{P} 1.00=\$ 0.024$

$\$ 1.00=\mathrm{P} 42.048$ 


\section{Abbreviations}

$\begin{array}{lll}\text { ADB } & - & \text { Asian Development Bank } \\ \text { ARMM } & - & \text { Autonomous Region in Muslim Mindanao } \\ \text { CAR } & - & \text { Cordillera Administrative Region } \\ \text { CDIA } & - & \text { Cities Development Initiative for Asia } \\ \text { CLUP } & - & \text { Comprehensive Land Use Plan } \\ \text { COBP } & - & \text { country operations business plan } \\ \text { CPS } & - & \text { country partnership strategy } \\ \text { DBP } & - & \text { Development Bank of the Philippines } \\ \text { DENR } & - & \text { Department of Environment and Natural Resources } \\ \text { DFID } & - & \text { Department for International Development of the United Kingdom } \\ \text { DILG } & - & \text { Department of Interior and Local Government } \\ \text { DMC } & - & \text { developing member country } \\ \text { DPWH } & - & \text { Department of Public Works and Highways } \\ \text { GDP } & - & \text { gross domestic product } \\ \text { GHG } & - & \text { greenhouse gas } \\ \text { GIS } & - & \text { geographic information system } \\ \text { HDMF } & - & \text { Home Development Mutual Fund } \\ \text { HLURB } & - & \text { Housing and Land Use Regulatory Board } \\ \text { HUC } & - & \text { highly urbanized city } \\ \text { HUDCC } & - & \text { Housing and Urban Development Coordinating Council } \\ \text { IRA } & - & \text { internal revenue allotment } \\ \text { JICA } & - & \text { Japan International Cooperation Agency } \\ \text { LBP } & - & \text { Land Bank of the Philippines } \\ \text { LDIP } & - & \text { Local Development Investment Plan } \\ \text { LGC } & - & \text { local government code } \\ \text { LGU } & - & \text { local government unit } \\ \text { LWUA } & - & \text { Local Water Utilities Administration } \\ \text { MDG } & - & \text { Millennium Development Goal } \\ \text { MWSS } & - & \text { Metropolitan Waterworks and Sewerage System } \\ \text { NCR } & - & \text { National Capital Region } \\ \text { NEDA } & - & \text { National Economic and Development Authority } \\ \text { NFPP } & - & \text { National Framework for Physical Planning: 2001-2030 } \\ \text { NHA } & - & \text { National Housing Authority } \\ \text { NSO } & - & \text { National Statistics Office } \\ \text { NUDHF } & - & \text { National Urban Development and Housing Framework } \\ \text { NUA } & - & \text { National Urban Assessment } \\ \text { NWRB } & - & \text { National Water Resources Board } \\ \text { PDP } & - & \text { Philippine Development Plan } \\ \text { PFS } & - & \text { prefeasibility study } \\ \text { PIDS } & - & \text { Philippine Institute for Development Studies } \\ & & \end{array}$




$\begin{array}{lll}\text { PPTA } & - & \text { project preparatory technical assistance } \\ \text { SEUW } & - & \text { South East Asia Urban Development and Water Division } \\ \text { SMES } & - & \text { small and medium-sized enterprises } \\ \text { STEP-UP } & - & \text { strategic private sector partnerships for urban poverty reduction } \\ \text { SWM } & - & \text { solid waste management } \\ \text { TA } & - & \text { technical assistance } \\ \text { UDHA } & - & \text { Urban Development and Housing Act } \\ \text { UOP } & - & \text { Urban Operational Plan } \\ \text { WSP } & - & \text { water service provider }\end{array}$





\section{Introduction}

T

he Asian Development Bank (ADB) launched its Urban Operational Plan (UOP) 2012-2020 at the Asian Urban Forum in November 2011. Under the UOP, ADB will support developing member countries (DMCs) in developing their urban economies, improving environmental sustainability, and making pro-poor investments. To maximize development impact, the urban sector can play an integrative role to provide a focus for ADB operations beyond traditional urban investments (ADB 2011d). The Manual on National Urban Assessments (NUA) provides an integrated framework for conducting rapid urban sustainability assessments at both national and urban region levels for DMCs to develop strategic policy options and targeted investments in the urban sector. This case study on the Philippines is based on the thematic areas of the NUA framework shown in Figure 1.

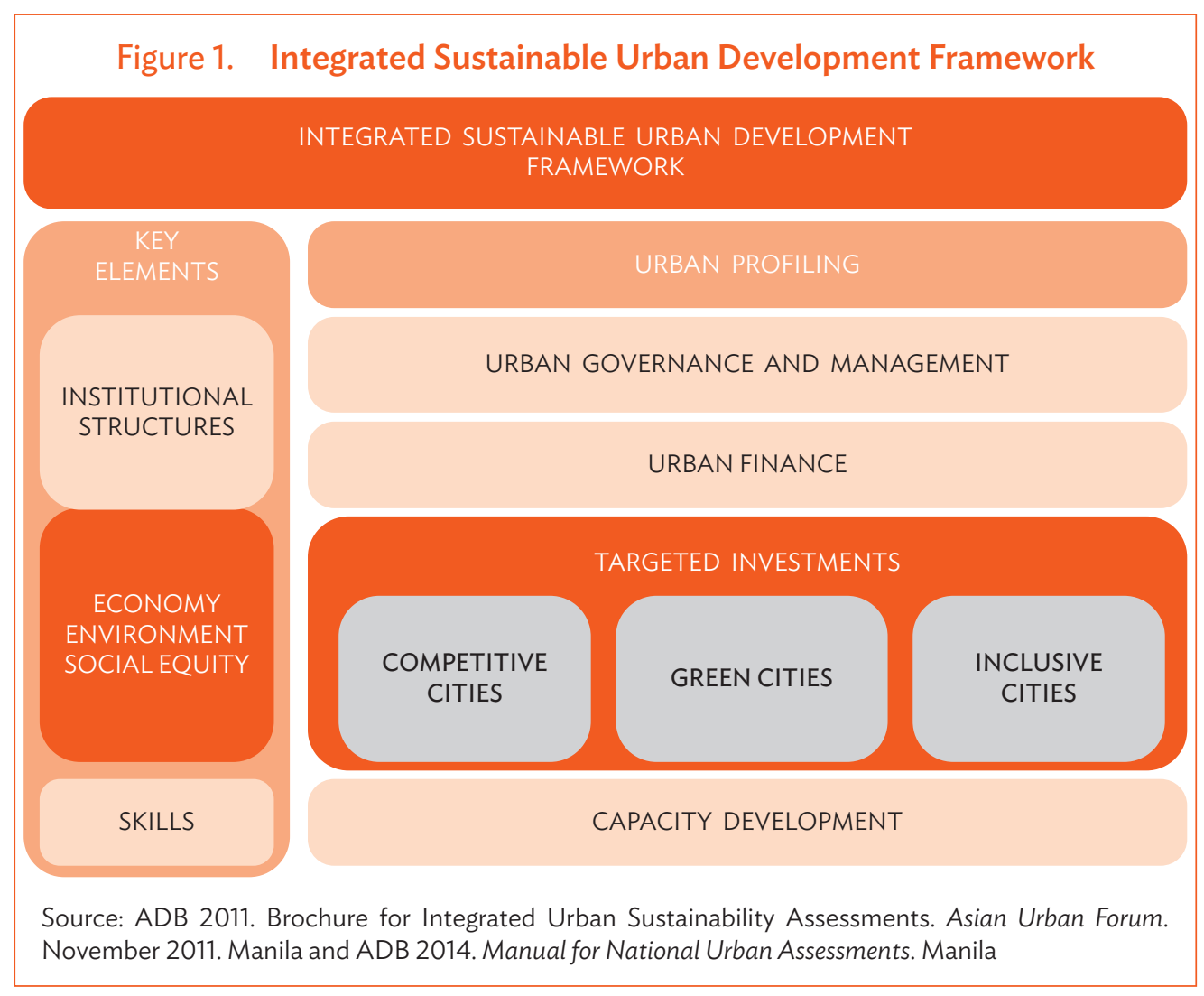




\section{Country Profile}

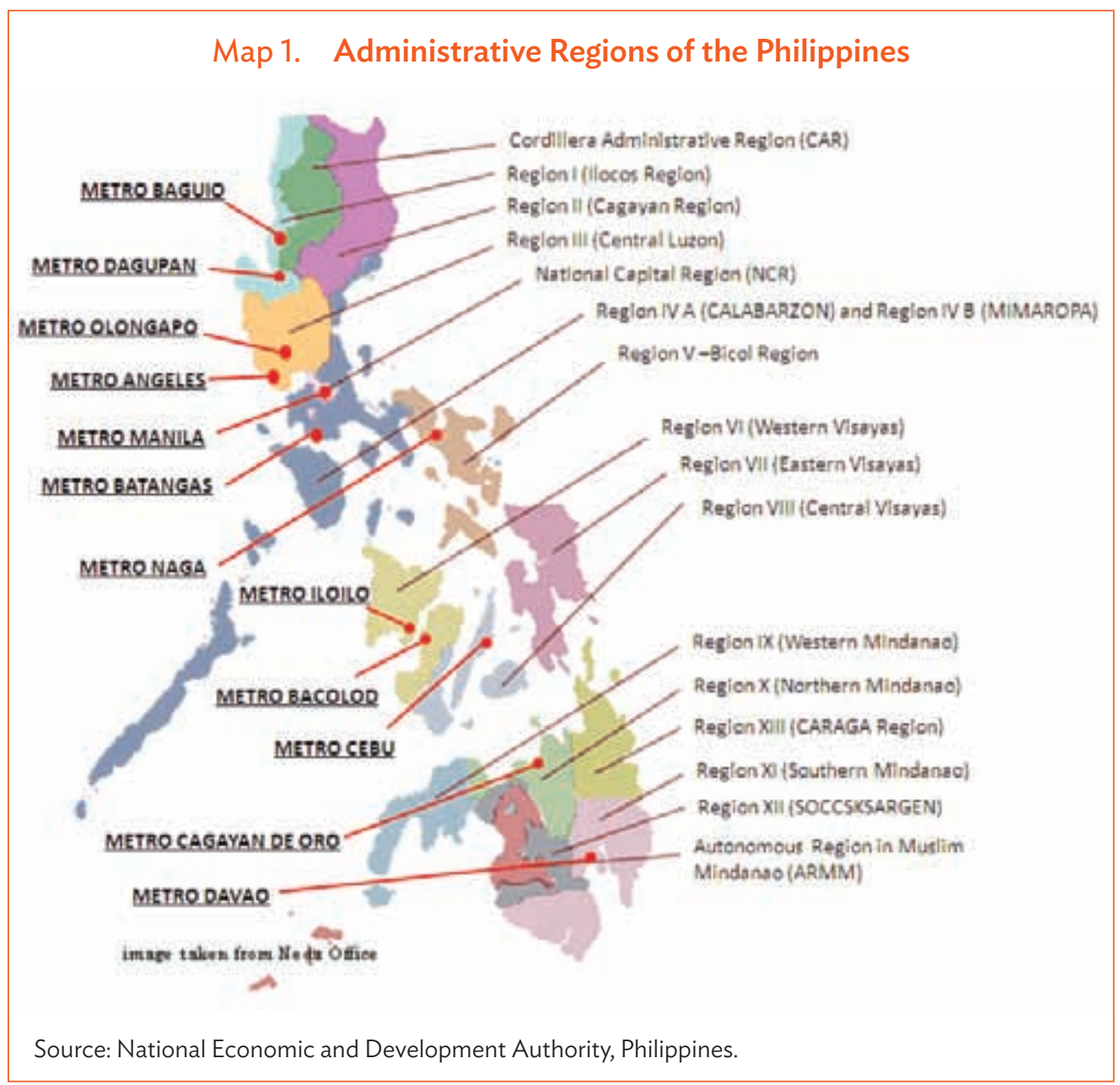

\section{Location}

The Republic of the Philippines is an archipelagic nation located southeast of mainland Asia in the western rim of the Pacific Ocean. 'The Philippines comprises 7,107 islands with a total land area, including inland bodies of water, of approximately 300,000 square kilometers $\left(\mathrm{km}^{2}\right)$. It is bounded by the Sulu Sea on the west and by the Celebes Sea and the coastal waters of

1 The Philippines consists of 7,107 islands spanning $1,840 \mathrm{~km}$; most of these $(6,700)$ have a land area of less than 1 square mile ( 2.6 square kilometers $\left[\mathrm{km}^{2}\right]$ ). The majority of the population resides on the 11 largest islands (NEDA 2002). 
Borneo on the south. The archipelago has a $36,289 \mathrm{~km}$ coastline, ${ }^{2}$ with approximately $60 \%$ of the population residing within 832 coastal municipalities, making it highly vulnerable to the impacts of climate change. ${ }^{3}$ The country has three main island groups. The northern group of Luzon is the largest with an area $141,000 \mathrm{~km}^{2}$, followed by Mindanao with 102,000 km², and the Visayas with $57,000 \mathrm{~km}^{2}{ }^{4}$ Administrative subdivisions comprise 17 regions, 80 provinces, 138 cities, 1,496 municipalities, and 42,025 barangays (village-level administrative units). ${ }^{5}$ The Philippine National Framework for Physical Planning: 2001-2030 (NFPP) has identified 12 metropolitan areas as the country's leading industrial, financial, and technological centers that serve as the main hubs for international trade. Manila, the capital city, is located in Metro Manila, the largest metropolitan area in the country.

- The archipelagic topography presents a challenge in communications, infrastructure development, and service delivery.

- With the fifth largest coastline in the world, more than $60 \%$ of the Philippine population is exposed to the impacts of climate change.

\section{Political History}

Historically, the northern parts of Luzon have traded with East Asian merchants, including the Chinese, from as early as the 3rd century. In the 1400s, the Japanese established a trading post in Northern Luzon. Manila, located in Luzon, has maintained its position as the seat of power and economics. The southern regions of Mindanao were historically ruled by Muslim sultans, the influence of which is reflected today in the cultural dominance of these regions. The Philippines, named after King Philip II of Spain, was under Spanish rule for 356 years until 1898 when, after the Spanish-American war, it went under American administration, and then finally became an independent republic in 1946.

2 World Bank. 2004. A Framework for Sustainable Philippine Archipelagic Development. ArcDev February 2004.

3 Department of Environment and Natural Resources (DENR). 2010. www.denr.gov.ph

4 National Economic and Development Authority (NEDA). 2002. National Framework for Physical Planning: 2001-2030. Mandaluyong City.

5 A local government unit (LGU) in the Philippines may be a province, a city, a municipality, or a barangay (neighborhood) in descending order of geographical scale and scope of political power. In geographical terms, each LGU has its own territorial jurisdiction but the smaller unit is embedded in the next higher unit forming a nested pattern. Thus, a barangay forms part of a municipality or city; a municipality is an integral part of a province, and a province is a component of the country as a whole. Politically, however, most cities are independent of any province although they are geographically located within a province. See ADB (2009a) and NSO (2012). 


\section{Political System}

The Philippines is a constitutional republic with a presidential system, governed as a unitary state with the exception of the Autonomous Region in Muslim Mindanao (ARMM). The three co-equal branches of government are the administrative, the legislative, and the judiciary. The current administration, led by President Benigno Aquino III, assumed office in June 2010 on a "no corruption, no poverty" platform centered on "a social contract with the Filipino People," and has carried out a vigorous anticorruption drive and initiated significant governance reforms. ${ }^{6}$ The government's commitment to good governance and sustainable fiscal management has increased investor confidence and trust in the public sector. However, a complex political economy dominated by strong personality-oriented and patronage-driven factions minimizes the role of political parties, leading to unpredictable legislative outcomes. This, in turn, leads to increased uncertainty and higher risks that are likely to impact the pace and quality of reforms.

The Philippine political economy is characterized by the strong roles of money, media, and personal influence, as well as the violence that coexists with institutionalized regular and competitive elections, combined with a high popular commitment to democracy (Co, Fernan, and Sta. Ana 2007). The political landscape is dominated by the parochial interests of an influential landed elite, as well as powerful political families and clans. Whereas "champion" politics can motivate development, it could also hamper sustainable institution building with transfers of power and political shifts within coalition politics. Persistent challenges against weak public institutions and inadequate accountability mechanisms, at both national and local levels, have reduced the quality of governance in recent years and, if left unaddressed, will pose risks to effective urban development management.

The decentralization legislation adopted in 1991 resulted in the devolution of considerable autonomy and sources of finance to local governments. This is an important precondition for adequate service delivery, given the archipelagic nature and geographical dispersion of the country. The capacity to carry out this mandate varies considerably across local governments and regions, and fragility in some areas-particularly in the conflict-affected areas of Mindanao-has affected service delivery. For instance, the country faces the Moro and

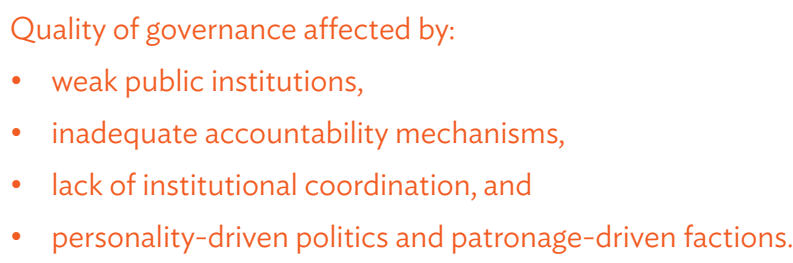

6 The election platform was publicly released on 28 November 2009. www.adb.org/sites/default/files/cpsphi-2011-2016.pdf

7 Fragility is understood as a situation with weak state capacity and/or weak state legitimacy that leaves citizens vulnerable to a whole range of shocks. See ADB (2011b). 
communist insurgencies in Mindanao, although there are ongoing efforts to end the conflict in Mindanao and foster economic development of regions lagging behind.

\section{Urbanization Profile}

\section{Demographic Analysis}

The Philippines is a highly urbanized nation. As early as 1980 , urbanization was at $37.2 \%$, and by 1990 it had reached $48.6 \%$. In 2000, urban areas were home to $48.1 \%$ of the country's 76.5 million inhabitants; by 2010 , those areas accounted for $48.9 \%$ of a total population of 94 million (Figure 2). Although the level of urbanization has been relatively steady with some fluctuation, there has been a steep increase in total urban population during the last decade. In merely 2 decades, the national population grew from 60 million in 1990 to 94 million by 2010 (Figure 3).

The annual percentage change in the total population went from $2.70 \%$ in 1980 to $2.10 \%$ in 2000, and further dropped to 1.94\% in 2010 (Figure 4). While the annual growth rate has declined over a period of 25 years, the urban growth rate remains higher than the national growth rate due to a high birth rate, in-migration, and to some extent the reclassification of local government units (LGUs) (Figure 5).

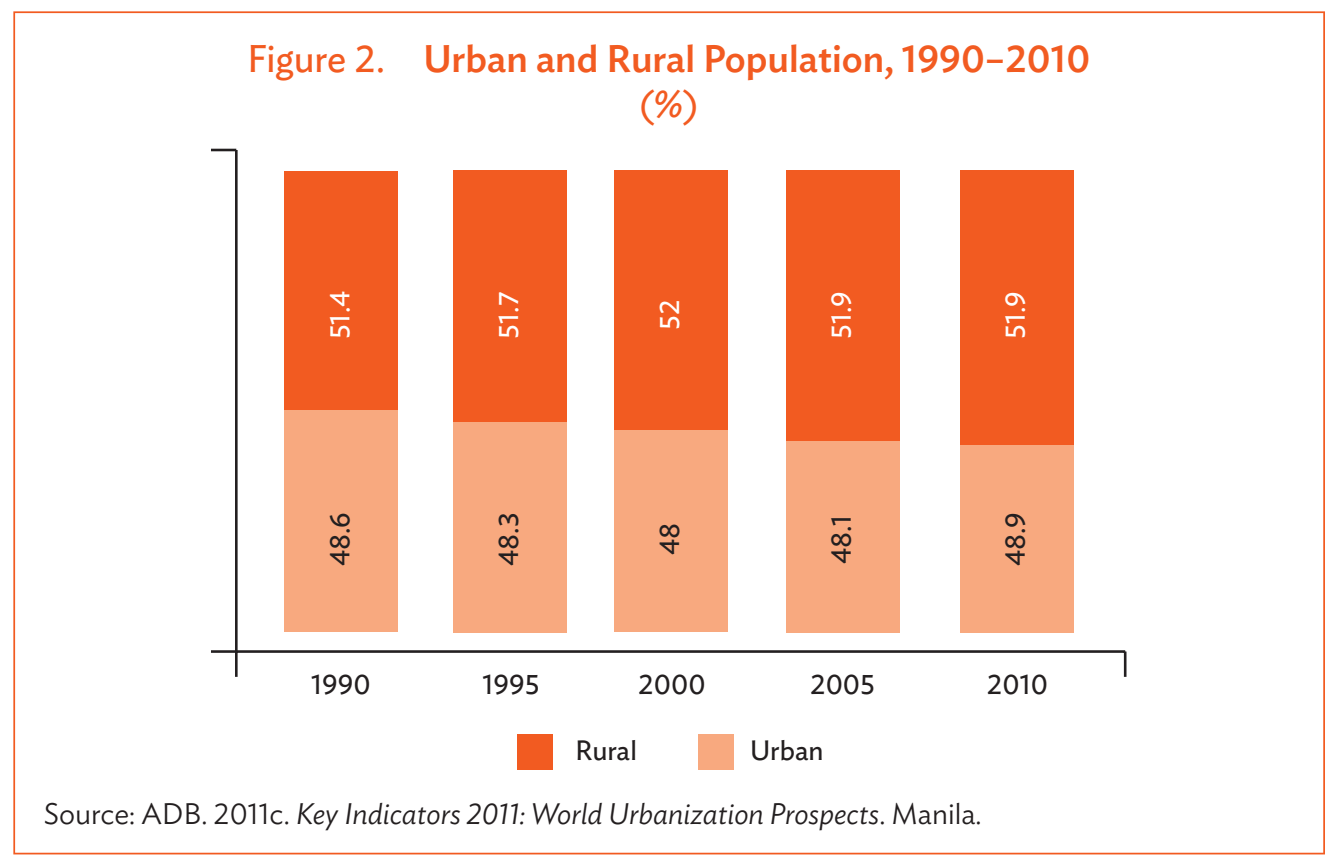


Figure 3. Total Population Change

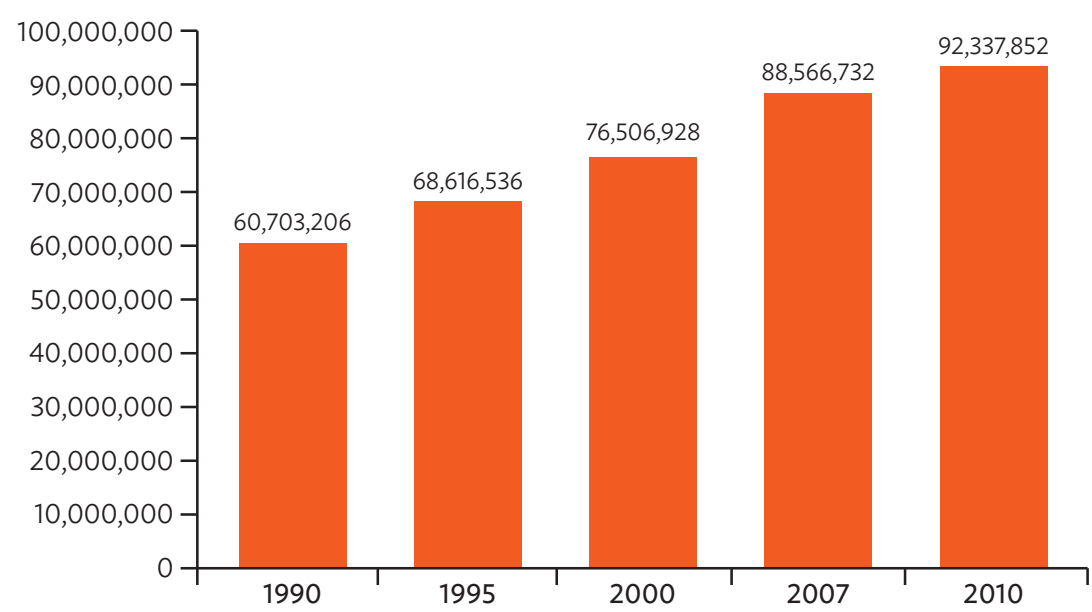

Source: ADB. 2011c. Key Indicators 2011: World Urbanization Prospects. Manila.

Figure 4. Total, Urban, and Rural Population, 1995-2010

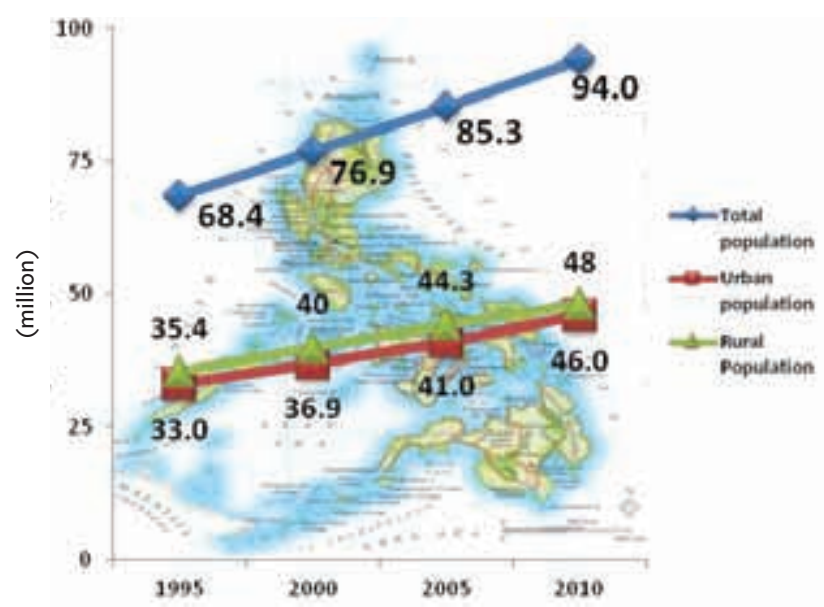

\begin{tabular}{|lcccc|} 
& 1995 & 2000 & 2005 & 2010 \\
\hline Total population (million) & 68.4 & 76.9 & 85.3 & 94.0 \\
Urban population (million) & 33.0 & 36.9 & 41.0 & 46.0 \\
Rural population (million) & 35.4 & 40 & 44.3 & 48 \\
Population annual change (\%) & 2.3 & 2.1 & 2.0 & 1.9
\end{tabular}

Source: ADB. 2011c. Key Indicators 2011: World Urbanization Prospects. Manila. 
Figure 5. Annual Growth Rate of Urban Population by Region, 1975-2000

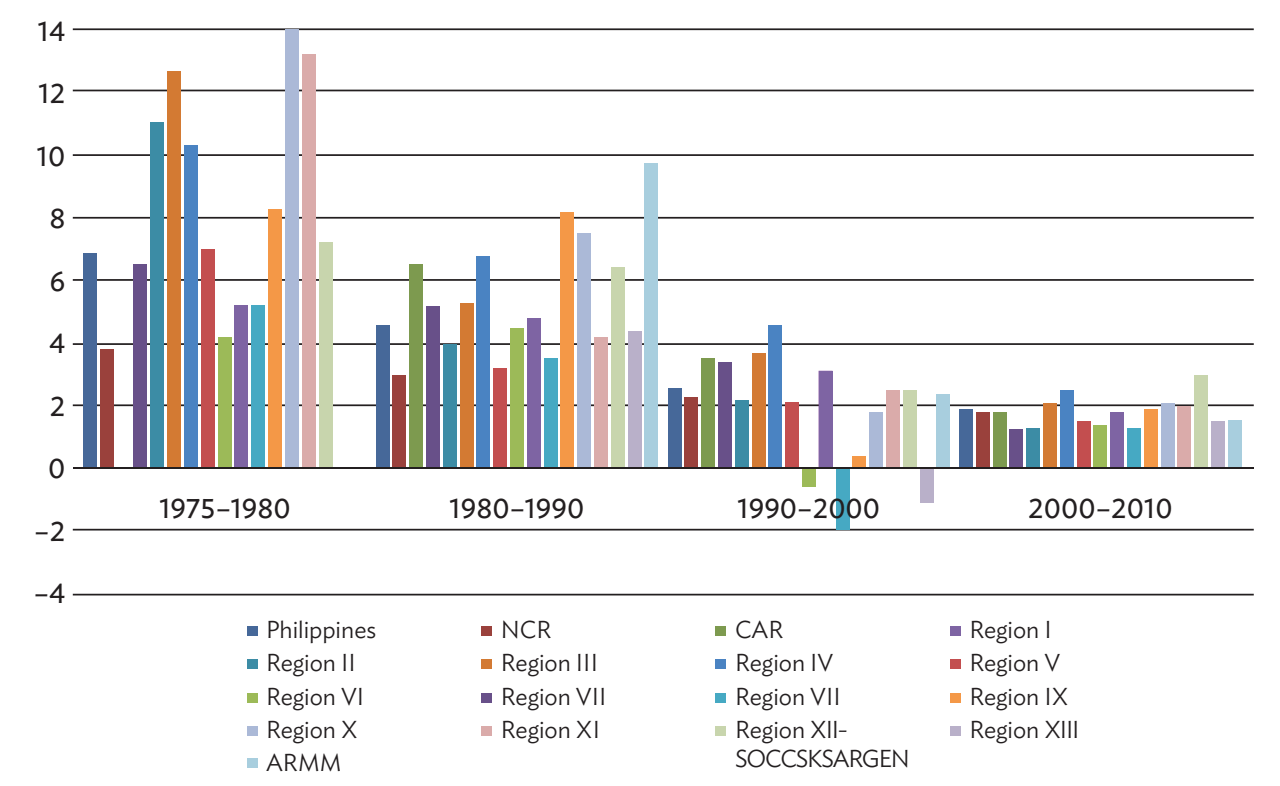

Source: National Statistics Office. 2010. Philippine Statistical Yearbook. Manila.

\section{Urbanization and Population Densities by Regions}

The Philippines has an average population density of 313 persons $/ \mathrm{km}^{2}$, a sharp increase from 255 persons $/ \mathrm{km}^{2}$ in $2000 .{ }^{8}$ Since 2000, the country's population has increased $1.9 \%$ annually, on average, to reach a total population of 92.34 million as reported by the 2010 census (Table 1). With 100\% urbanization, the National Capital Region (NCR) is the most densely populated area in the country with $18,165.1$ persons $/ \mathrm{km}^{2}$ spread over an administrative land area of $636 \mathrm{~km}^{2}$ constituting only $0.2 \%$ of the total land area of the country $^{9}$ (Figure 6).

The Cordillera Administrative Region (CAR) is the least densely populated area, with 78 persons $/ \mathrm{km}^{2}$ and an urbanization level of $38.2 \%$. Other regions with high levels of urbanization are Region III, Central Luzon (60.5\%); Region VII, Central Visayas (46.4\%); and Region IV, Southern Tagalog (58.2\%), which has been divided into IV (A-CALABARZON) and IV (B-Mimaropa $)^{10}$ (Figure 7). Of the 17 regions in the Philippines, the corridor comprising the urban areas of Cavite, Laguna, Batangas, Rizal, and Quezon (CALABARZON), which are adjacent to Metro Manila, is now the most populated area in the country with 12.61 million inhabitants. The population of the CALABARZON corridor now surpasses that of the NCR (comprising Metro Manila; 11.86 million), and Central Luzon (10.14 million). Furthermore,

8 National Economic and Development Authority (NEDA). 2002. National Framework for Physical Planning: 2001-2030. Mandaluyong City.

9 Siemens AG. 2011. Asian Green City Index. Munich.

10 CALABARZON stands for Cavite, Laguna, Batangas, Rizal, and Quezon. 
Table 1. Projected Levels of Urbanization

\begin{tabular}{|c|c|c|c|c|c|c|c|}
\hline Indicator & 1990 & 2000 & 2001 & 2005 & 2010 & 2020 & 2030 \\
\hline Total population (thousands) & 61,040 & $76,213.1$ & 77,131 & 84.566 .2 & $93,000.9$ & 108,748 & 122,388 \\
\hline Population in urban (thousands) & 29,774 & $44,621.4$ & 45,812 & $53,031.8$ & $61,730.8$ & $78,594.7$ & $93,859.6$ \\
\hline Population in slums (thousands) & 16,346 & - & 20,183 & 22,768 & - & - & - \\
\hline $\begin{array}{l}\text { Population in urban areas } \\
\text { (\% of total population) }\end{array}$ & 49.0 & - & 59.0 & - & 66.4 & 72.3 & 76.7 \\
\hline $\begin{array}{l}\text { Population in slums } \\
\text { (\% of urban population) }\end{array}$ & 55.0 & - & 44.0 & 43.7 & - & - & - \\
\hline $\begin{array}{l}\text { Annual urban population growth } \\
\text { rate (\%) }\end{array}$ & 4 & - & 4 & - & - & - & - \\
\hline $\begin{array}{l}\text { Annual slum population growth } \\
\text { rate }(\%)\end{array}$ & 2 & - & 2 & - & - & - & - \\
\hline $\begin{array}{l}\text { Population with access to improved } \\
\text { sanitation (\% of urban population) }\end{array}$ & - & - & 87 & - & - & - & - \\
\hline $\begin{array}{l}\text { Population with access to improved } \\
\text { water (\% of urban population) }\end{array}$ & - & - & 92 & - & - & - & - \\
\hline $\begin{array}{l}\text { Population with sufficient living } \\
\text { area ( } \% \text { of urban population) }\end{array}$ & - & - & 72 & - & - & - & - \\
\hline $\begin{array}{l}\text { Population with durable structures } \\
\text { (\% of urban population) }\end{array}$ & - & - & 95 & - & - & - & - \\
\hline
\end{tabular}

- = data not available.

Sources: United Nations, Department of Economic and Social Affairs, Population Division. 2008. World Urbanization Prospects: The 2007 Revision. New York; UN-Habitat, Urban Info 2008.

Figure 6. Population Density (persons $/ \mathrm{km}^{2}$ ) vs. Land Area by Region, 2010

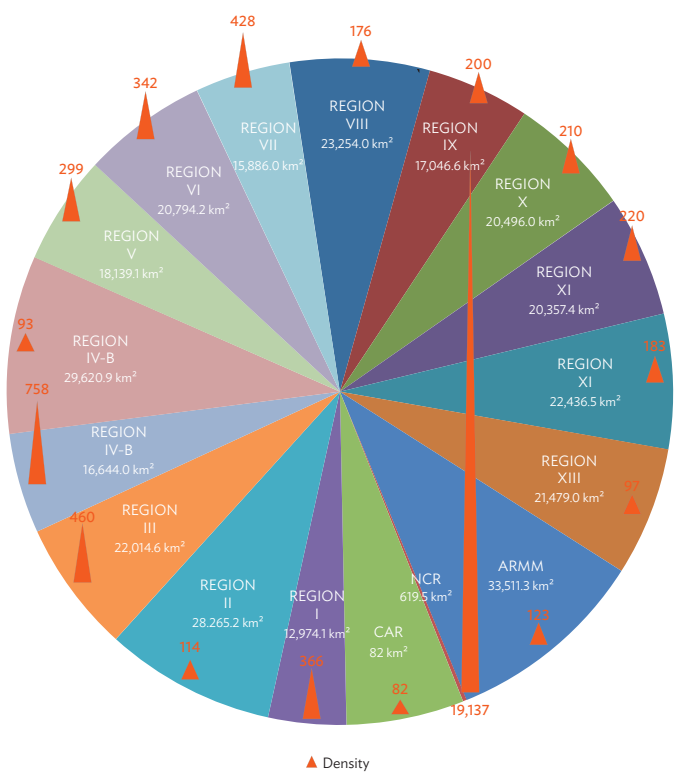

Source: National Statistics Office. 2010. Philippine Statistical Yearbook. Manila. 
33 cities, including all 16 cities in the NCR, are now classified as highly urbanized cities (HUCs), four of these being home to more than a million inhabitants." These four HUCs comprise three that are located in the NCR (Caloocan City [1.49 million], the City of Manila [1.65 million], and Quezon City [2.76 million]), as well as Davao City (1.45 million) on the southern island of Mindanao.

The high level of urbanization of Region III and Region IV, which are in close proximity to Metro Manila, are indicative of suburbanization and peri-urban development due to the spillover of economic activity into these urban regions. Regions with declining levels of urbanization include Region XI, Southern Mindanao, from 49.10\% in 1990 to 38.00\% in 2000; and Region X, Northern Mindanao, from $42.80 \%$ to $40.50 \%$ in the same period. In both cases the decline is attributable to the conflict in these regions. Rapid urbanization is putting significant pressure on urban infrastructure, especially in secondary cities, which are growing the fastest (Figure 7).

\footnotetext{
- High level of urbanization: 48.9\% urban population out of a total population of 94 million

- Urban population growth rate remains higher than the national growth rate

- Over three-quarters of the total population is projected to be living in urban areas by 2030

- For every one person living in a rural area, three will be in an urban area
}

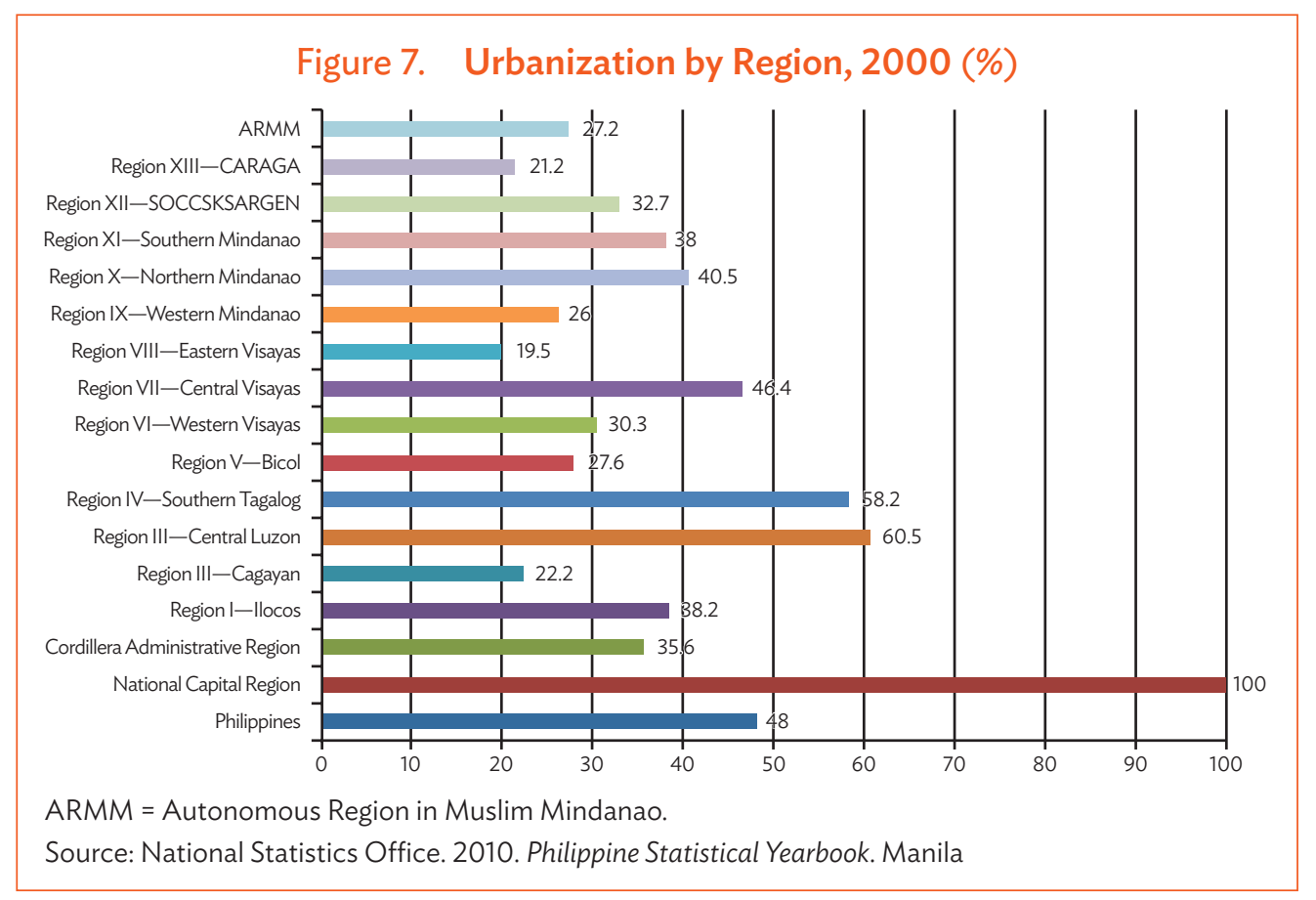

11 Cities with a minimum population of 200,000 inhabitants (as certified by the National Statistics Office), and with an annual income of at least P50 million in 1991 constant prices, as certified by the city treasurer. 


\section{Spatial Analysis}

Spatial distribution analysis shows a concentration of urban settlements along the national highways, especially the Maharlika Highway, part of which aligns with the Nautical Highway, and along coastal highways, with the highest concentrations seen in the vicinity of Metro Manila (Map 2). The NFPP has identified 12 metropolitan areas as being the country's leading industrial, financial, and technological centers, which serve as the main hubs for international trade. These are Metro Manila, Metro Cebu, Metro Davao, Metro Cagayan de Oro, Metro Angeles, Metro Iloilo, Metro Bacolod, Metro Naga, Metro Baguio, Metro Batangas, Metro Dagupan, and Metro Olongapo. Metro Manila ranks as the most densely populated area among the identified metropolitan areas, while Metro Cagayan de Oro is the least dense area. Metro Manila, the largest urban agglomeration, has been the political and economic driver of the nation since Spanish colonial times (Figure 8). Of the 10 most populous cities in the country, 5 are in Metro Manila (Figure 9). With a population that continues to grow, mainly due to high birth rates, Metro Manila remains the leading economic, sociocultural, and educational center of the country despite signs that some cities, like Manila for example, are now experiencing a negative trend in urban population. There is some evidence of the growing movement of development into surrounding regions. Other cities, such as Cebu and Davao (in Region VII and Region X), are now growing relatively faster, reducing somewhat the primacy of Metro Manila. ${ }^{12}$ Although Manila remains the hub for international travelers, in recent years with the emergence of the Cebu Pacific Airways as a major regional airline, Cebu has gained prominence as a transport hub for tourism and export-oriented activities.

\section{Migration}

Historically, Filipinos have sought a better quality of life through migration. In the early years, rural folk from the provinces moved to bigger cities for employment opportunities. In recent years the trend has moved toward international migration at a phenomenal scale as increasingly large numbers of Filipinos leave for other countries, some on a permanent basis but most of them to work temporarily (Figure 10). This trend has affected the lives of millions of Filipinos, restructured social institutions, and altered the face of the country's economy. Overseas Filipino workers (OFWs) have become an institution in themselves.

- The Philippines is a highly urbanized nation.

- The archipelagic topography leads to a spatially dispersed population and urban sprawl.

- Peri-urban development is evident around major urban economic growth centers

Recommendations:

- Address regional disparities, urban imbalance, and migration by supporting development in secondary cities and smaller towns to build sustainable communities.

- Raising densities in urban areas is essential to accommodate projected population increases, address urban sprawl, and sustain economic growth.

- Peri-urbanization of smaller towns and secondary cities to stimulate economic growth could further capture the benefits of urbanization.

12 ADB. 2008b. Managing Asian Cities. Manila. 
Map 2. Urban Settlements in the Philippines, 2010

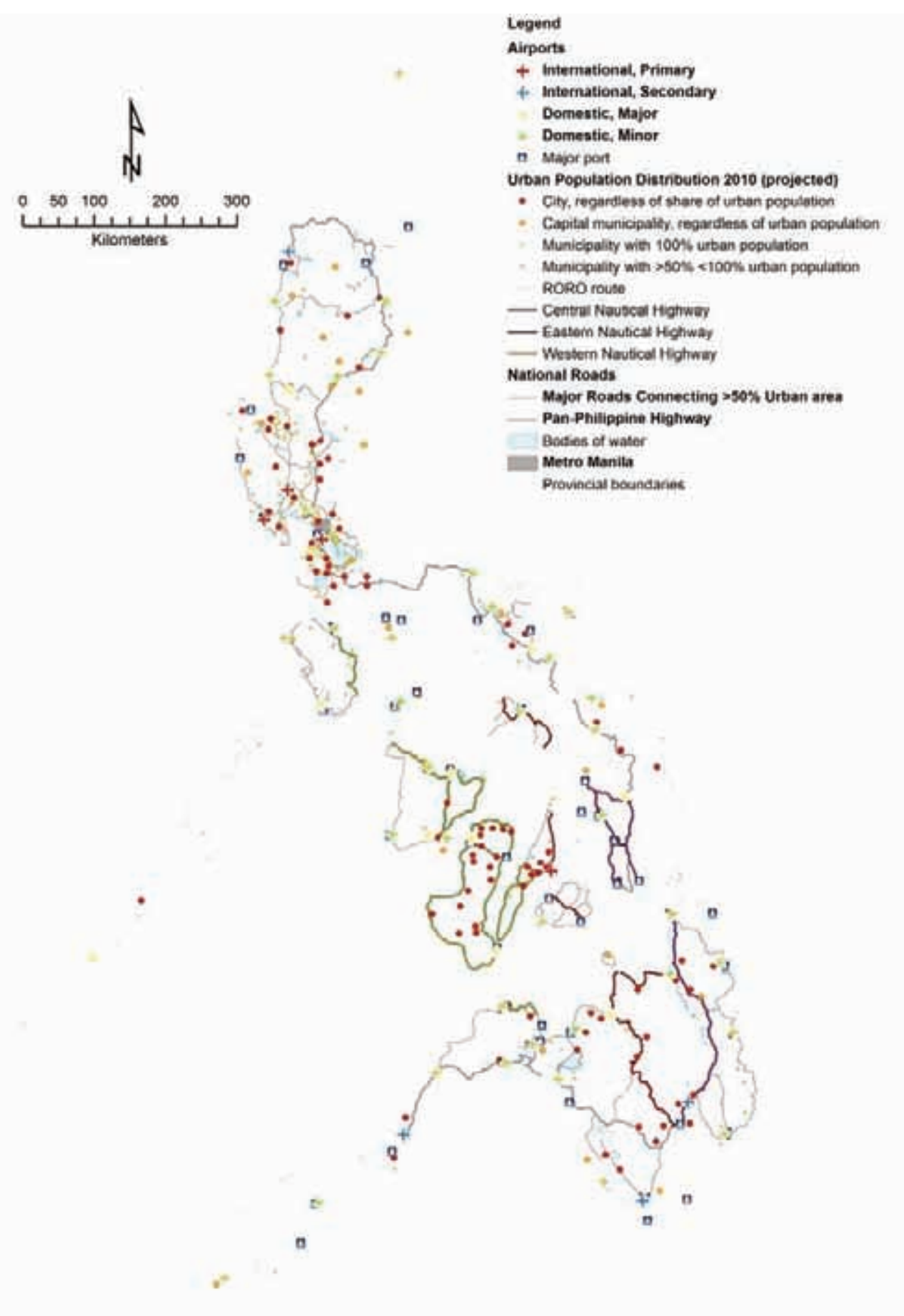

RORO = roll-on/roll-off.

Source: National Statistics Office. 2010. Philippine Statistical Yearbook. Manila. 
Figure 8. Population Density and Area of Metropolitan Regions, Philippines, 2007

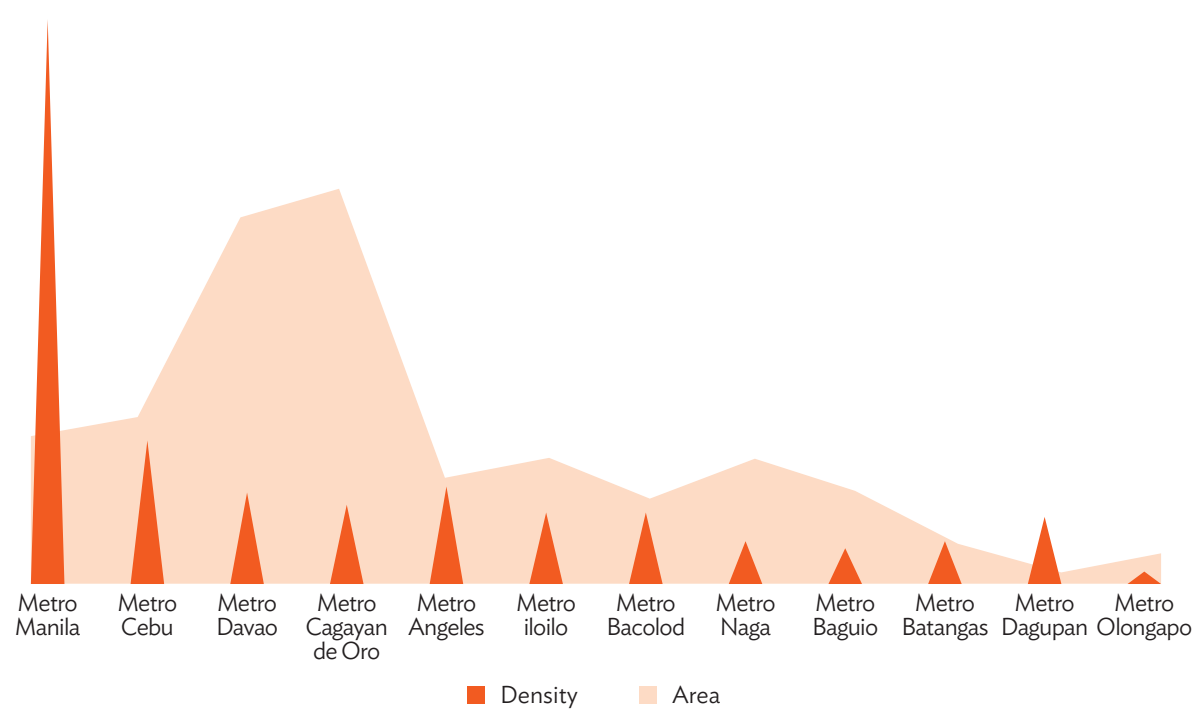

Source: National Statistics Office. 2010. Philippine Statistical Yearbook. Manila.

Figure 9. Ten Most Populous Cities in the Philippines, 1990-2007

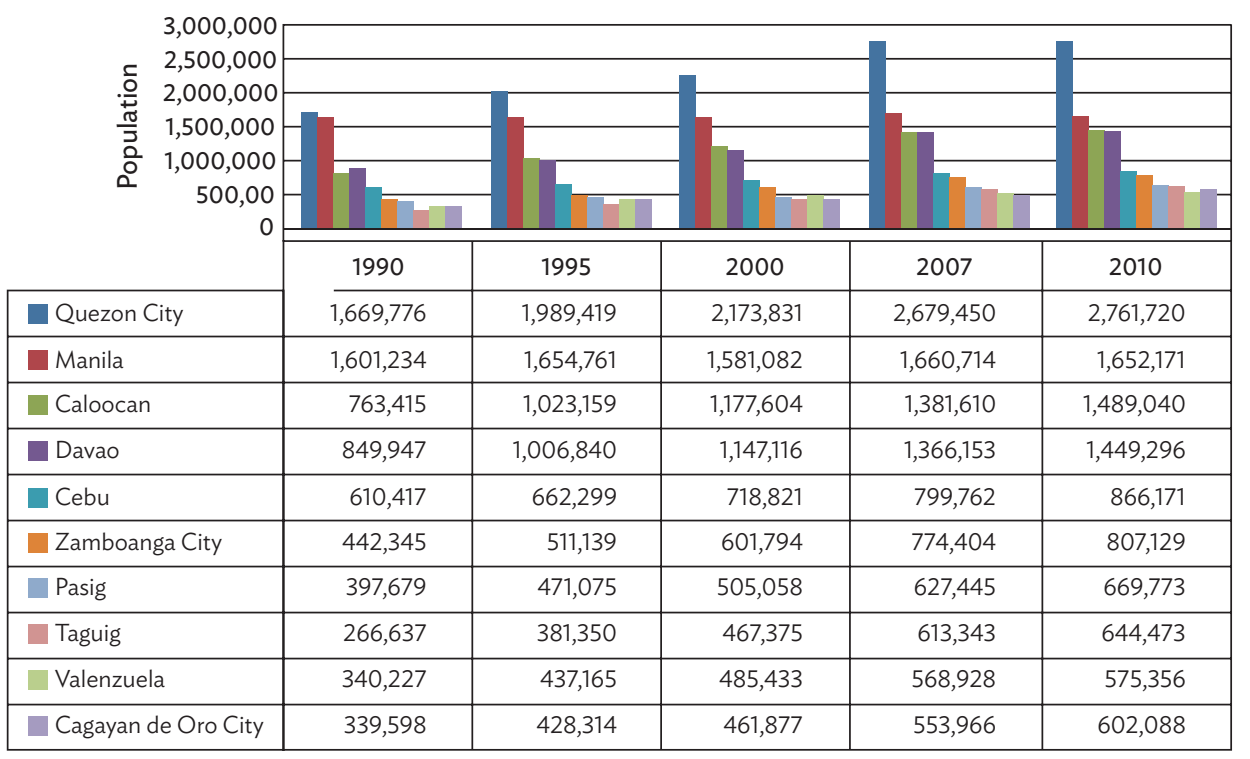

Source: National Statistics Office. 2010. Philippine Statistical Yearbook. Manila. 
Figure 10. Net International Migration Rate, Philippines, 1990-2010

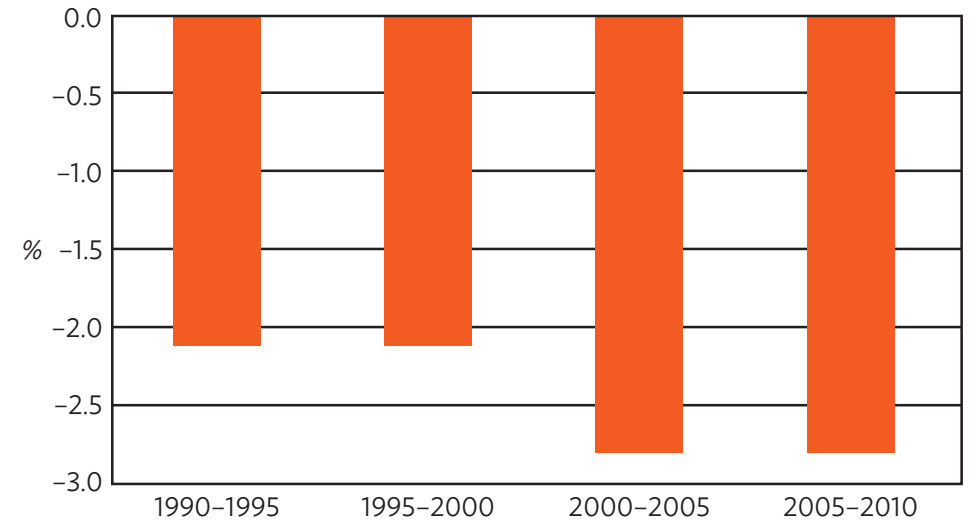

Source: Philippine Statistical Year Book, National Statistics Office. 2010.

These temporary migrant workers stay abroad for the limited duration of their job contracts, repatriating money to their families and thus substantially bolstering the country's economy. Of the total stock estimate of overseas Filipinos in 2006, over 3.8 million (46\%) were temporary migrants. Permanent migrants made up $43 \%$, and $11 \%$ were irregular migrants..$^{13}$

\section{Land Use and Land Management}

The Philippine archipelago comprises 7,107 islands with a total land area-including inland bodies of water- of $299,404 \mathrm{~km}^{2}$, or approximately 30 million hectares (ha). Broadly divided into three major island groups, the northern group of Luzon is the largest with an area $141,000 \mathrm{~km}^{2}$, followed by Mindanao, $102,000 \mathrm{~km}^{2}$, and the Visayas, $57,000 \mathrm{~km}^{2} .^{14}$

The largest share of the country's total land resources is classified as forest land, amounting to $65 \%$ or 19.10 million hectares. The area of designated arable and developed land made up 47.3\% of the country's total land in 2009 (Figure 11). With urban land being a scarce resource, increasingly there has been conversions of large swathes of irrigated agricultural land, in Central Luzon and Southern Tagalog, to a variety of urban and industrial uses including export processing zones and industrial estates, institutions, leisure landscapes, and residential subdivisions. ${ }^{15}$

Land use policies related to urban land use classification and land conversions need to be reviewed in order to establish a well functioning, coordinated system of land management at all tiers of governance. Land use planning has been devolved to LGUs, and data on urban land use is maintained by several agencies, leading to fragmented responsibilities in land

13 Philippine Commission on Population. 2004. State of the Philippine Population Report. Manila.

4 Footnote 8.

15 P. Kelly. 1998. The Politics of Urban-Rural Relations: Land Use Conversion in the Philippines. Environment and Urbanization. 10 (1). pp. 35-54. 
Figure 11. Land Classification, 2009

(\%)

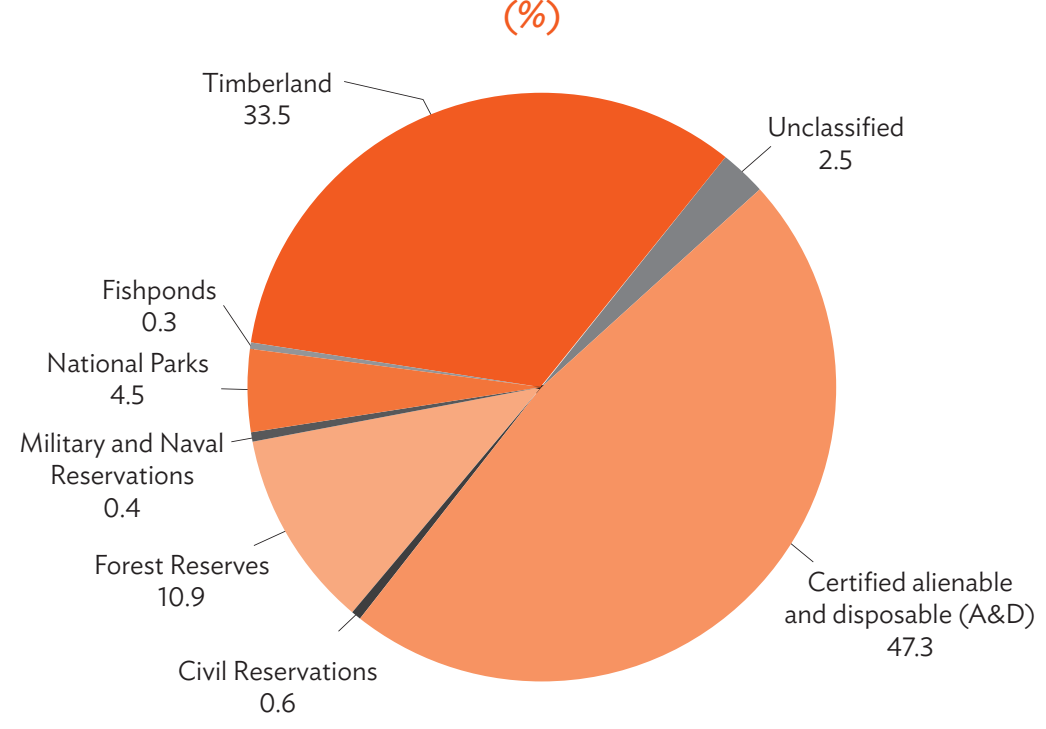

Source: National Statistics Office. 2010. Philippine Statistical Yearbook. Manila.

management and administration. Time delays in awarding development permits have led to higher transaction costs translating into a high cost of housing. ${ }^{16}$ These inefficiencies in the regulatory processes must be tackled with transparent and accountable systems to enable organizational reform to improve governance in the real estate market. The property taxation system does not encourage development. A centralized land use database system with geographic information system (GIS) mapping should be developed to aid the government in tapping land value through efficient land management and integrated urban planning. This would increase the efficiency of property tax collection.

- Scarce land resources and inefficient land management

- Unregulated and unplanned land conversions

- High transaction costs for development permits leads to high cost of housing

Recommendations:

- Develop a land use database system with GIS mapping for efficient land management

- Review land use policies pertaining to land use classification and land conversions

- Introduce transparent and accountable systems for awarding development permits

16 Footnote 15. 


\section{Governance and Urban Management Profile}

\section{Decentralization and Devolution}

The 10th Congress enacted the 1991 Local Government Code (LGC) or Republic Act (RA) 7160, enabling considerable administrative and fiscal devolution to LGUs, ${ }^{17}$ an important precondition for adequate service delivery given the archipelagic nature and geographical dispersion of the country. However, service delivery has been affected by fragility ${ }^{18}$ in the conflict-affected areas of Mindanao facing the Moro and communist insurgencies. This challenging governance environment has been linked with the country's low competitiveness rating, and low elasticity of poverty to economic growth. ${ }^{19}$

Although the decentralization process is generally deemed to have been a success, the lack of governance mechanisms for coordination of planning, implementation, and operation of regional-scale infrastructure and services has resulted in negative impacts on environmental quality, transport, and economic competitiveness. ${ }^{20}$ Inadequate vertical-horizontal coordination, weak linkages between plans, and tiered governance contribute to fragmented and conflicting urban policies.

Interjurisdictional cooperation to create extended urban regional cooperation at the metropolitan level is hampered by the propensity of city governments to function in a geographical vacuum. To address this constraint, the Government of the Philippines has recently moved toward "metropolitanization" to create a coordinating authority that can address common problems of urban areas through concerted efforts and pooled resources. However, conflicting factors such as the political autonomy of mayors, and the sharing and/or transfer of administrative powers and resources from LGUs to metropolitan authorities have often led to dysfunctional implementation arrangements. For instance, in promoting sustainable urban renewal along the Pasig River, the Pasig River Rehabilitation Commission faces a monumental challenge in bringing together the various municipalities, agencies, and institutions under whose jurisdiction the river traverses.

\section{Institutional Structures for Urban Development}

The National Economic and Development Authority (NEDA), the country's independent economic development and planning agency, is headed by the president as chair of the NEDA board, with the secretary of socioeconomic planning, concurrently NEDA director general, as vice-chair. The Central Bank governor, ARMM, and the Union of Local Authorities of the Philippines as well as several cabinet members are members of the NEDA board. NEDA

\footnotetext{
Footnote 5.

18 Fragility is understood as a situation with weak state capacity and/or weak state legitimacy that leaves citizens vulnerable to a whole range of shocks. See ADB. 2011b. Country Partnership Strategy: Philippines, 2011-2016. Manila.

19 ADB. 2011b. Thematic Assessment (Summary): Good Governance and Political Economy. Country Partnership Strategy: Philippines, 2011-2016. Manila.

20 World Bank. 2005. East Asian Urbanization: Objectives, Policies and Programs. Philippines.
} 
prepares the 30-year long-term development plan. The institutional structure in Chart 1. shows the various agencies involved in the delivery of urban development in the Philippines. The key agency responsible for delivering urban development in the Philippines is the Housing and Urban Development Coordinating Council (HUDCC). With a large housing deficit and a mandate weakened by a lack of commensurate resource allocation powers, HUDCC has primarily concerned itself with administration and delivery of housing. ${ }^{21}$

The lack of a clear, coherent, and integrated institutional framework with supportive public sector institutional arrangements has led to a dysfunctional sector with duplications and overlapping functions due to a lack of synchronization of mandates amongst the various players outside the purview of the HUDCC. The National Urban Development and Housing Framework (NUDHF) strategy recognizes the need to enhance coordinative mechanisms at various levels. It also identifies fundamental issues related to urban policy formulation and implementation, vertical and horizontal linkages among institutions performing functions relevant to housing and urban development (Chart 2), as well as the need to synchronize areabased plans and programs with sector priorities. It is essential to improve interfacing between local government officials and representatives of regional and national government agencies (NGAs) to improve implementation at the local project level. It is imperative for HUDCC to broaden its scope to coordinate urban development management to meet the objectives and goals outlined in the updated NUDHF. However, in the absence of budget control and resource allocation powers, HUDCC is inherently weak as the coordinative mechanism at the national level, and presents a strong case for the formation of a Department of Housing and Urban Development. ${ }^{22}$

- Involvement of many institutions with overlapping mandates resulting in inadequate vertical-horizontal institutional coordination for planning, implementation, and operation of infrastructure and services

- Need to synchronize area-based plans and programs with sector priorities

Recommendations:

- HUDCC should broaden its scope to coordinate urban development management.

- Metropolitan governance should be the responsibility of a single authority.

- There is a need to improve coordination between local government officials and representatives of regional and national government agencies (NGAs) to improve implementation at the local level.

\section{Key Urban Development Framework}

The National Framework for Physical Planning: 2001-2030 (NFPP), a long-term plan prepared by the National Economic and Development Authority (NEDA), is the key strategic urban development framework that sets policy and planning guidelines for land-use planning

21 ADB. 2009a. Institutional Strengthening of Housing and Urban Development Sector. Final Report. Manila. ADB. 2001. Development of Poor Urban Communities Project. Final Report. Manila.

22 See ADB (2009a). 


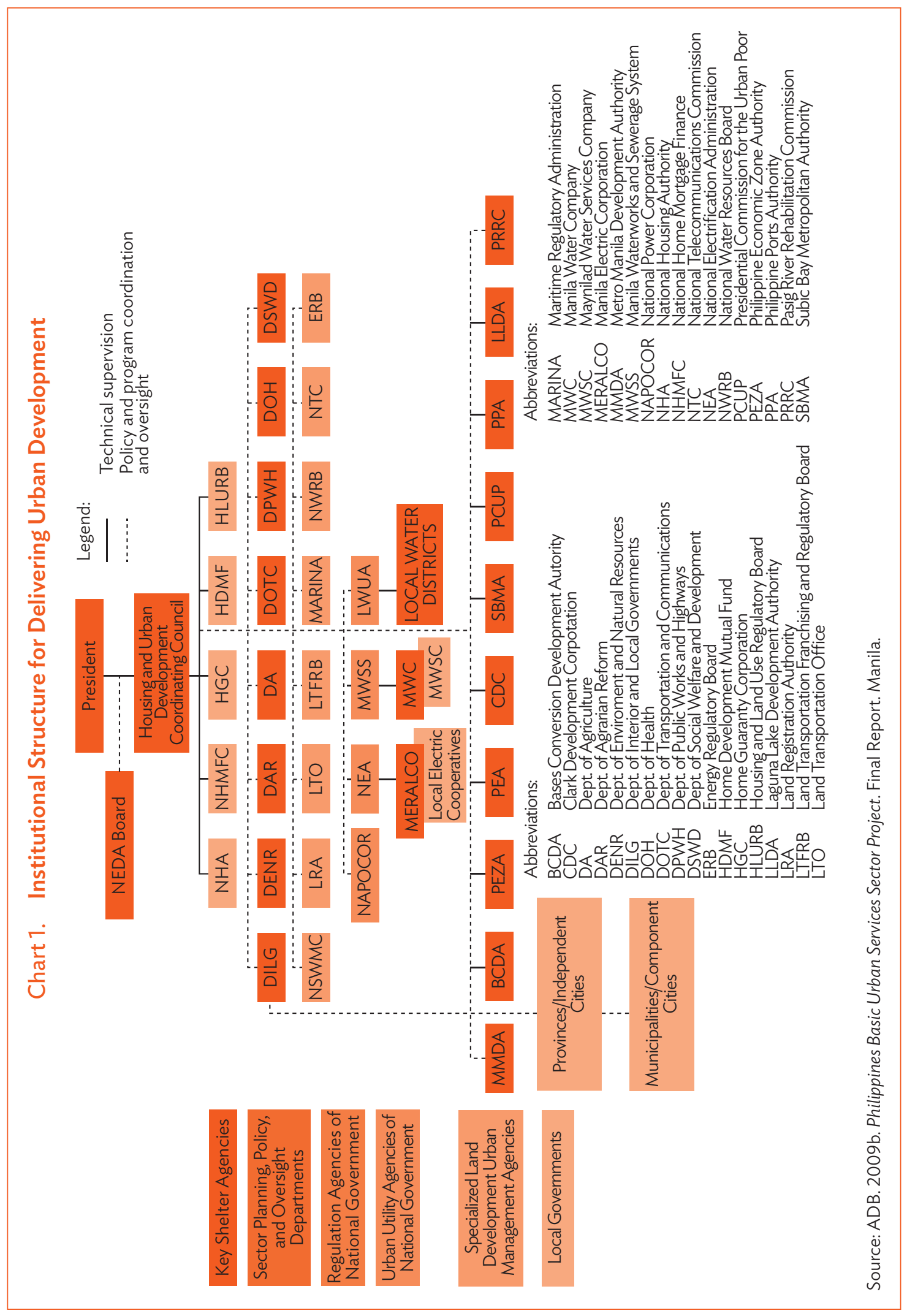


in the country. The NFPP is aligned with the goals of the Philippine Development Plan (PDP) ${ }^{23}$ 2011-2016 (Chart 3), the short-term economic development plan of the government in power. The vision of national development is anchored in sustainable development and growth with social equity. To achieve the national vision, land use as well as physical and related planning activities shall proceed within the context of the principles that support the allocation and use of land and water resources with due regard to their sustainability.

The HUDCC is responsible for developing and updating the government's medium-term national spatial strategy, the NUDHF, in concurrence with the NFPP. The updated NUDHF

\section{Chart 2. Functional Areas and Responsibilities for Urban Services}

\begin{tabular}{|c|c|c|c|c|c|c|c|c|c|c|c|c|c|c|}
\hline Activity & $\begin{array}{l}\cup \\
\text { ํㅗ }\end{array}$ & 吕 & 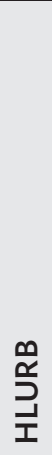 & 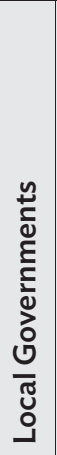 & 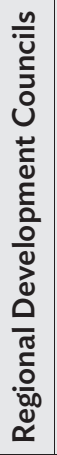 & ๖ำ & 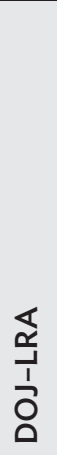 & 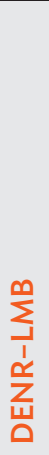 & 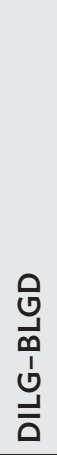 & $\underset{z}{\frac{\nwarrow}{\alpha}}$ & 늠 & $\sum_{0}^{\frac{1}{0}}$ & 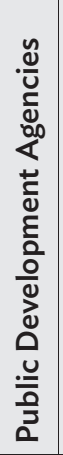 & 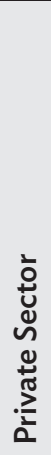 \\
\hline \multicolumn{15}{|l|}{ Policy } \\
\hline National & $\bullet$ & $\bullet$ & & & & $\bullet$ & & & & & $\bullet$ & $\bullet$ & & \\
\hline Local & & $\bullet$ & & & $\bullet$ & & & & & & & & & \\
\hline \multicolumn{15}{|l|}{ Land Use Management } \\
\hline Overall planning & & $\bullet$ & & & & & & & & & & & & \\
\hline Land records & & & & & & & $\bullet$ & $\bullet$ & & $\bullet$ & & $\bullet$ & $\bullet$ & \\
\hline Land management & & & & & & & & $\bullet$ & & & & & $\bullet$ & \\
\hline Physical planning & & & $\bullet$ & & & & & & & & & & & \\
\hline Monitoring local plans & & & & & & & & & $\bullet$ & & & & & \\
\hline Mapping and data & & & & & & & & & & $\bullet$ & & $\bullet$ & & \\
\hline \multicolumn{15}{|l|}{ Land Use Planning } \\
\hline Regional & & $\bullet$ & $\bullet$ & & $\bullet$ & & $\bullet$ & & & & & & & \\
\hline Provincial & & & $\bullet$ & $\bullet$ & & & & & & & & & & \\
\hline City and Municipal & & & $\bullet$ & $\bullet$ & & & & & & & & & & \\
\hline \multicolumn{15}{|l|}{ Development Planning } \\
\hline Regional & & $\bullet$ & & & $\bullet$ & & & & & & & & & \\
\hline Provincial & & $\bullet$ & & & & & & & & & & & & \\
\hline City and Municipal & & & & $\bullet$ & & & & & & & & & & \\
\hline
\end{tabular}

DILG-BLGD = Department of the Interior and Local Government-Bureau of Local Government Development, DOJ-LRA = Department of Justice-Land Registration Authority, DOT = Department of Tourism, DOTC $=$ Department of Transportation and Communications, DPWH $=$ Department of Public Works and Highways, HLURB = Housing and Land Use Regulatory Board, HUDCC = Housing and Urban Development Coordinating Council, NEDA = National Economic and Development Authority.

Note: Public development agencies include Metro Manila Development Authority, Subic Bay Metropolitan Authority, Clark Development Authority, Bases Conversion Development Authority and Public Estates Authority, and other integrated area development agencies with Urban Development Planning Functions.

Note: Orange = national; black = local.

Source: ADB. 2009b. Philippines Basic Urban Services Sector Project. Final Report. Manila.

23 Previously known as the Mid-Term Philippine Development Plan. 


\section{Chart 3. Philippines Urban Planning Framework: Tiers and Linkages}

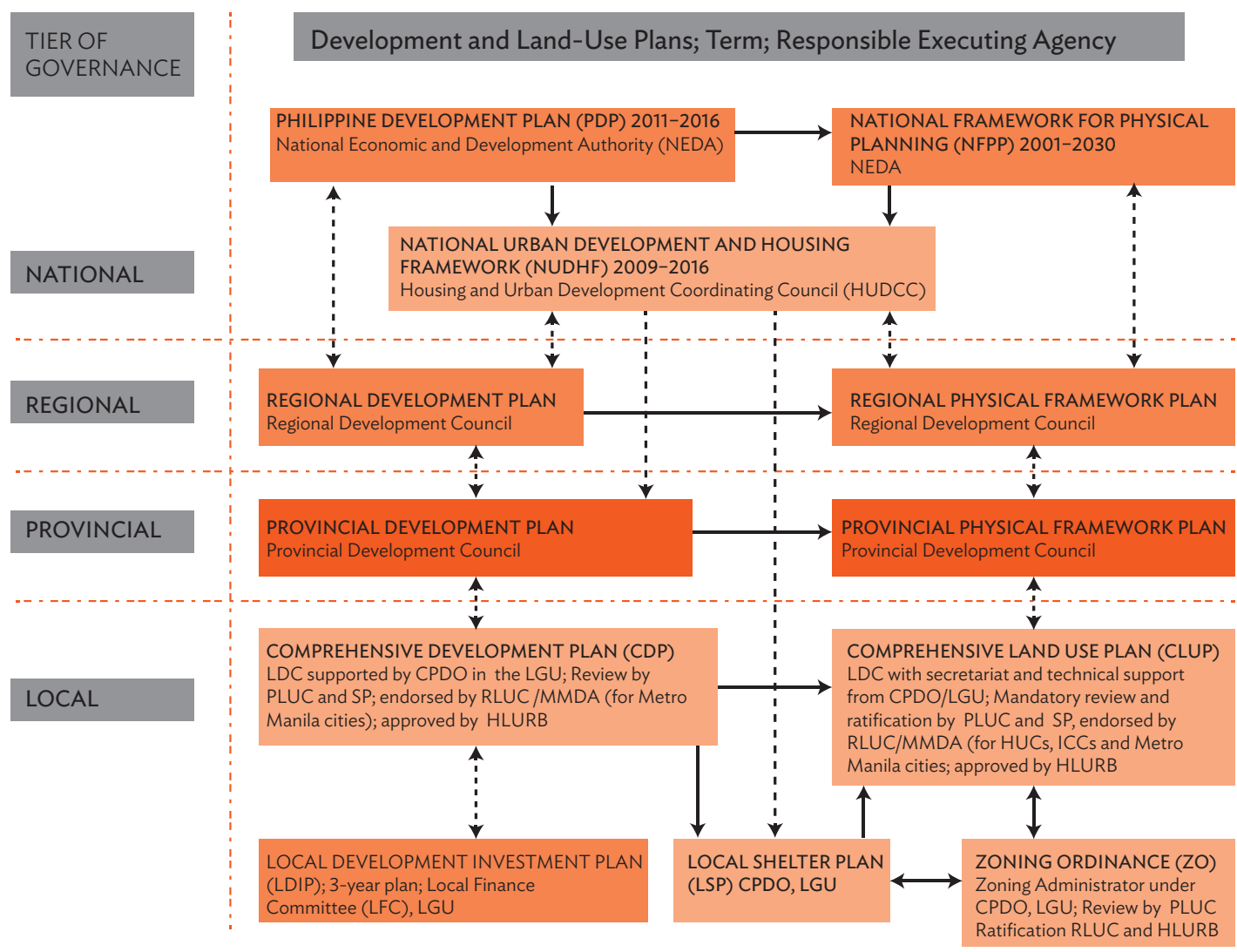

$\mathrm{CPDO}=$ City Planning Development Office, HLURB = Housing and Land Use Regulatory Board, HUCs = highly urbanized cities, ICCs = Independent Component Cities, LDC = Local Development Councils, LGU = local government unit, MMDA = Metro Manila Development Authority, PLUC = Provincial Land Use Committees, RLUC = Regional Land Use Committee, $\mathrm{SP}=$ Sangguniang Panlalawigan.

Source: Author's analysis.

2009-2016 describes the vision for urban development as a system that facilitates economic growth, develops and strengthens local competitive advantage, and significantly improves the quality of life of its residents.

\section{Key Urban Development Legislation}

The key legislations considered critical to urban planning in the Philippines are the Urban Development and Housing Act (UDHA) of 1992 or RA 7279, and the LGC or RA 7160. UDHA was enacted to provide for a comprehensive and continuing urban development and housing program, establishing the mechanism for its implementation. UDHA empowered the LGUs to address urban development issues, paved the way for participatory governance, and ensured private sector participation in the national shelter program through a mandatory requirement to set aside $20 \%$ of all proposed subdivision areas for socialized housing. This mandatory requirement can be offset through payment for units to the National Housing Authority (NHA), the building arm of the government, responsible for construction of social 
housing. However, flexibility in meeting these requirements through provision of offsite housing, often far from the urban center, contradicts the purpose of providing affordable social housing for the urban poor near employment opportunities. Consequently, the provision of social and affordable housing within metropolitan areas remains inadequate.

The LGC mandates LGUs to prepare a comprehensive land use plan (CLUP) enacted through a zoning ordinance, and to prepare a comprehensive development plan, as well as other multisector development plans and public investment programs including the local development investment plan (LDIP). However, the capacity to carry out this mandate differs across local governments and regions.

Key legislations for the Philippine urban sector include:

Urban Development and Housing Act of 1992 or RA 7279 (24 March 1992) - providing for a comprehensive and continuing urban development and housing program by guiding urban land use and development and by addressing the need for affordable housing.

Republic Act 7835 (16 December 1994)-the Comprehensive Integrated Shelter and Financing Act of 1994.

Executive Order 71-devolution of Housing and Land Use Regulatory Boards' (HLURB) function to approve subdivision plans to LGUs.

Local Government Code or RA 7160 - mandates LGUs to a prepare a CLUP enacted through a zoning ordinance, and to prepare a comprehensive development plan, other multisector development plans and public investment programs including the local development investment plan (LDIP).

- Executive Order No. 72-providing for the preparation and implementation of CLUPs of LGUs pursuant to the LGC of 1991 and other pertinent laws.

- Memorandum Circular No. 54-prescribing the guidelines of Sec. 20, RA 7160, authorizing cities and/or municipalities to reclassify lands into nonagricultural uses.

- Executive Order No. 124-establishing priorities and procedures in evaluating areas for land conversion in regional agricultural and/or industrial centers, tourism development areas, and sites for socialized housing.

Batas Pambansa 220 - an act authorizing the Ministry of Human Settlements to establish and promulgate different levels of standards and technical requirements for economic and socialized housing projects in urban and rural areas from those provided under Presidential Decrees No. 957, 1216, 1096, and 1185.

Executive Order No. 82 (8 December 1986) —creating the Presidential Commission for the Urban Poor.

- Executive Order No. 69 (29 March 2012)-for strengthening the Presidential Commission for the Urban Poor.

- Executive Order 184-creating socialized housing one-stop processing centers. 


\section{Urban Finance Matrix}

The government has limited fiscal capacity to meet the urban development needs (Chart 4). Government financing institutions (GFIs), principally the Land Bank of the Philippines (LBP) and the Development Bank of the Philippines (DBP), are the major source of medium-term loans for LGUs. GFls have maintained a competitive advantage over the private sector in lending rates mainly because of their access to concessional official development assistance funds. Private financial institutions are hesitant to lend to LGUs because of their poor creditworthiness stemming from (i) unsecured and unpredictable asset and revenue base; (ii) insufficient information on their own financial operations; (iii) weak resource mobilization capacities; (iv) lack of internal revenue allotment (IRA) intercept; (v) poor cost recovery track records due to political intervention and poor collection procedures and systems; and (vi) lack of capacity in project planning, packaging, and implementation. ${ }^{24}$

The government has launched a program to attract private infrastructure investment by promoting public-private partnerships (PPPs). Improving the domestic investment climate to encourage the domestic banking sector and the private sector to invest in infrastructure is crucial to attaining long-term development goals. Moreover, strengthening tax revenues to

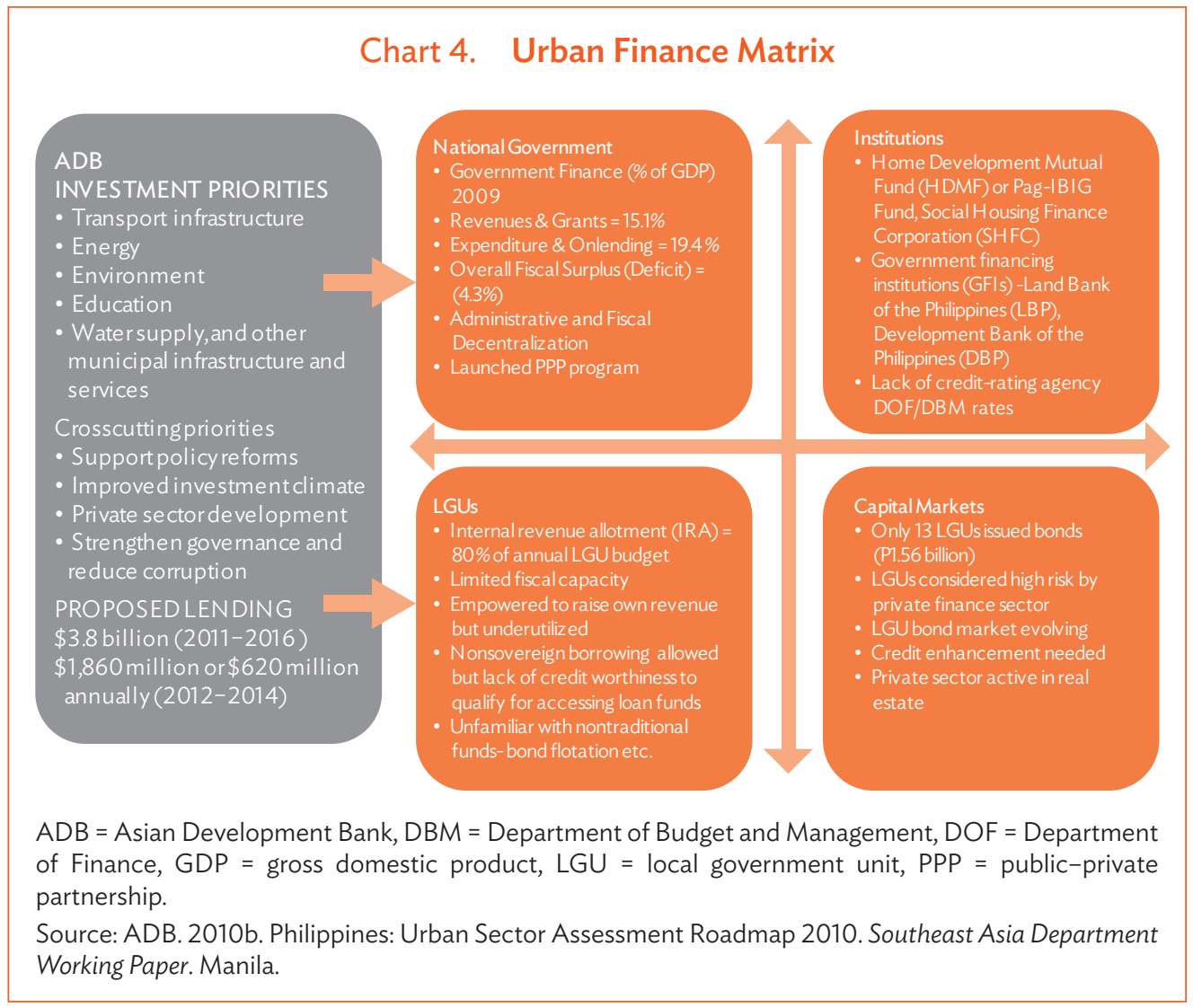

$24 \quad$ ADB. 2010b. Philippines: Urban Sector Assessment Roadmap 2010. Southeast Asia Department Working Paper. Manila. 
ensure adequate resources for social and physical infrastructure development is requisite to sustainable economic growth.

Decentralization requires fiscal sustainability. LGUs are responsible for urban management and delivery of location-specific urban services. The LGC established an intergovernmental transfer mechanism - the IRA — for sharing the revenues of the government while allowing local governments to raise their own revenues (Chart 5). Infrastructure investments and delivery of social services are largely dependent on IRA and non-IRA funding to LGUs, which finance almost $80 \%$ of their annual budget (Charts 6 and 7 ).

According to the LGC, the IRA share of LGUs should be computed as $40 \%$ of the national internal revenue taxes collected in the third fiscal year preceding the current fiscal year. The National Internal Revenue Code of the Philippines (RA 8424 or the Tax Reform Act) identifies the national internal revenue taxes that are sources of IRA as income tax, estate and donor's tax, other percentage taxes, excise taxes, documentary stamp taxes, and such other taxes that may be imposed and collected by the Bureau of Internal Revenue. IRA computation does not include revenue from import and customs duties and taxes, including the import value-added tax, collected by the Bureau of Customs on behalf of the Bureau of Internal Revenue. This interpretation of the "internal" revenue by the current Aquino administration has led to contentious debate in the Senate and litigation challenging the computation of the IRA. Furthermore, the formula for computation of the IRA is reliant

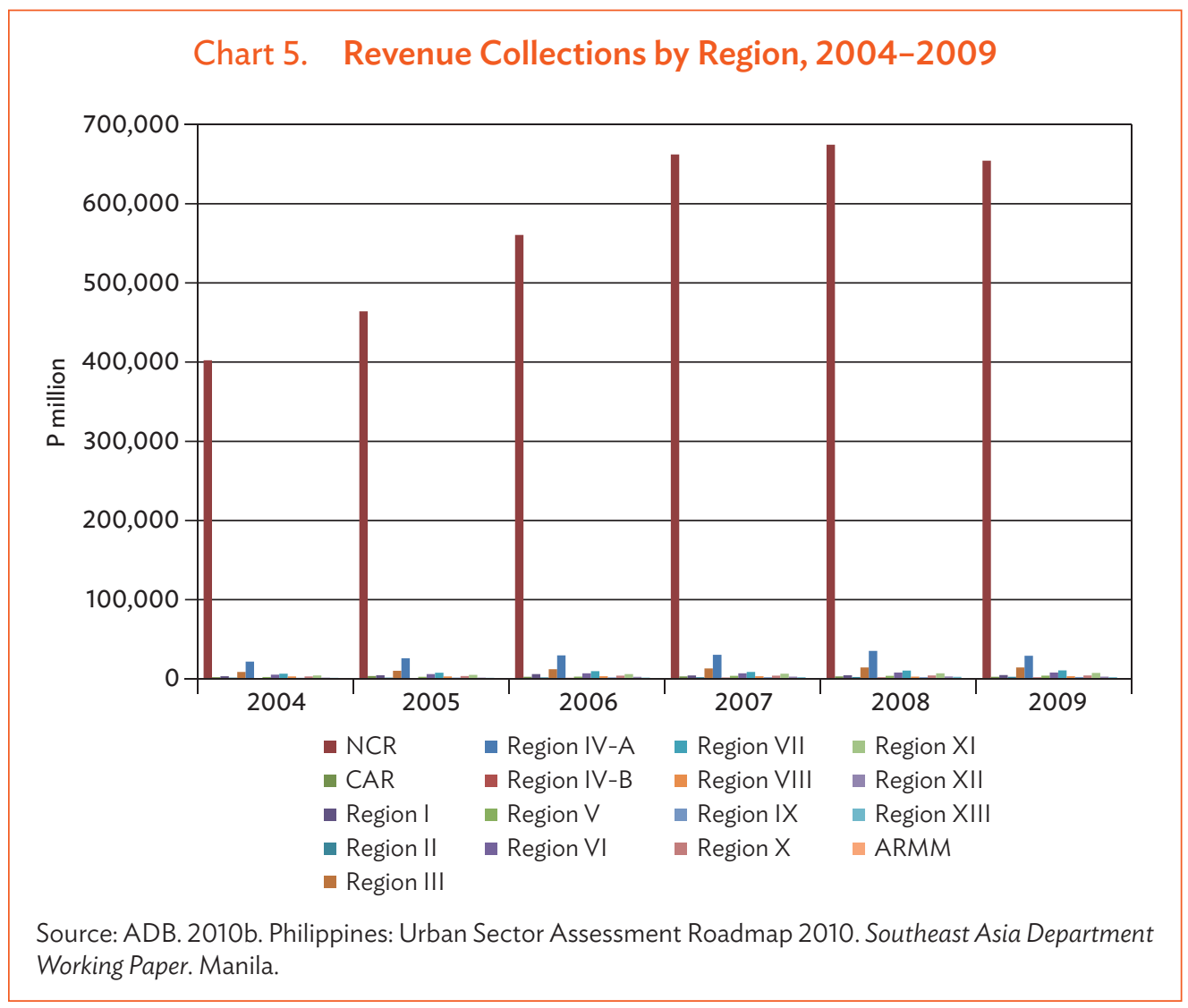




\section{Chart 6. Sources and Types of Income of Local Government Units}

\begin{tabular}{|c|c|c|}
\hline Source & Type & Details \\
\hline \multirow{7}{*}{ Internal/Local } & \multirow{3}{*}{ Tax Revenues } & Real Property Tax \\
\hline & & Business Tax \\
\hline & & Other Taxes \\
\hline & \multirow{4}{*}{ Non-Tax Revenues } & Regulatory Fees \\
\hline & & Service/User Charges \\
\hline & & Receipts from Economic Enterprises \\
\hline & & Toll Fees \\
\hline \multirow{11}{*}{ External } & \multirow{3}{*}{ Share from National Tax Collections } & Internal Revenue Allotment (IRA) \\
\hline & & Share in National Wealth \\
\hline & & Share in Economic Zone \\
\hline & \multirow{4}{*}{ Extraordinary Receipts/Grants/Aids } & Grants (Foreign and Domestic) \\
\hline & & National Aids \\
\hline & & Share from Lotto \\
\hline & & Rebates from MMDA Contributions \\
\hline & \multirow{2}{*}{ Loans and Borrowings } & Foreign (WB, ADB, etc.) \\
\hline & & Domestic (LBP, DBP, PNB, etc.) \\
\hline & \multirow{2}{*}{ Inter-Local Transfers } & Bond Flotation \\
\hline & & Countryside Development Fund \\
\hline
\end{tabular}

$\mathrm{ADB}=$ Asian Development Bank, DBP = Development Bank of the Philippines, $\mathrm{LBP}=$ Land Bank of the Philippines, $\mathrm{MMDA}=$ Metropolitan Manila Development Authority, PNB = Philippine National Bank, $\mathrm{WB}=$ World Bank.

Source: ADB. 2009. Philippines Basic Urban Services Sector Project. Final Report. Manila (TA 7062).

on the tax collection of the third fiscal year preceding the current fiscal year, often leaving LGUs with a lower budget than the previous year. Thus, LGUs will get lower IRA allocations in 2012 and 2013 due to the lower tax collections in 2009 and 2010 owing to the global financial crisis (Box 1).

This unpredictability of available national and local government funds creates difficulties for capital investment planning, leading to a backlog of projects. Compounding the resource crunch is an evident lack of financial sustainability for the operation and maintenance of existing infrastructure assets. Financial accountability, transparency, and the capacity of LGUs to work efficiently all need to be improved. Most LGUs spend more in administering taxes (such as real property tax) than they collect in revenues ${ }^{25}$ (Figure 7). Systemic obstacles to implementing projects in the Philippines such as startup delays, ineffective flow of funds to LGUs through intermediaries, and insufficient capacity of implementing agencies (especially at the LGU level) need to be addressed for effective urban development. ${ }^{26}$

ADB. 2003. Local Government Finance and Bond Markets. Manila.

26 ADB. 2011b. Country Partnership Strategy: Philippines, 2011-2016. Manila. 
Chart 7. Internal Revenue Allotments by Region, 2005-2010

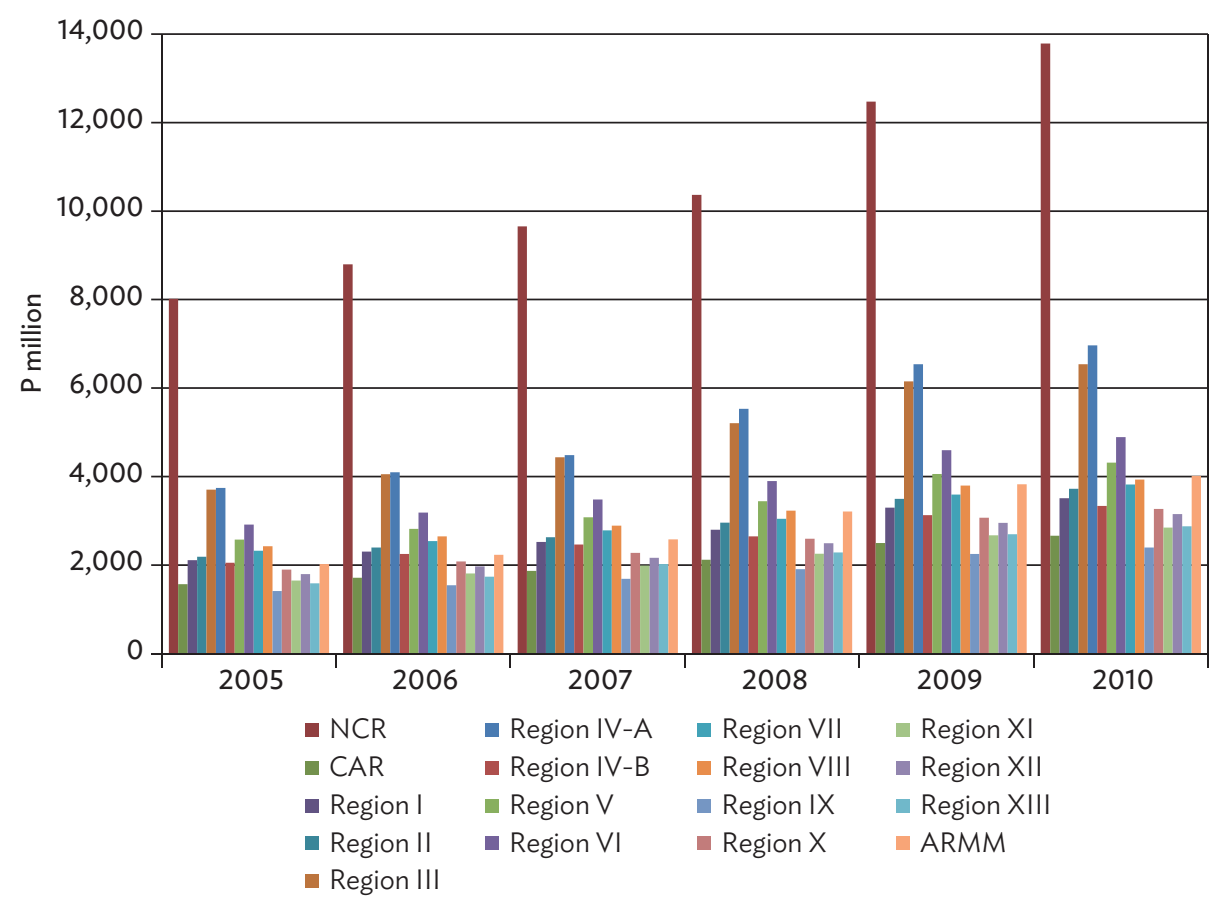

Source: ADB. 2010b. Philippines: Urban Sector Assessment Roadmap 2010. Southeast Asia Department Working Paper. Manila.

\section{Legislative and Regulatory Framework}

Structural changes and reforms have a strong impact on creating an enabling environment conducive to establishing competitive business as well as stimulating private sector investment in urban development. As seen in Box 2, the impact of reforms on the business environment can be positive or negative, e.g., the Government of the Philippines eased business startup by setting up a one-stop shop at the municipal level.

\section{Enabling Environment}

Creating an enabling environment is key to developing urban competitiveness in a global economy. The Doing Business Report 2011 ranked the economy of the Philippines 136th on a worldwide ranking, and 20th in the East Asia and Pacific Region (World Bank 2012) for the "Ease of Doing Business." The rankings use three indicators: (i) ease of starting a business, (ii) dealing with construction permits, and (iii) registering property. These indicators are a cumulative result of a host of variables connected to the regulatory environment ranging from getting electricity to registering a property, from getting credit to protecting investors and enforcing contracts. 


\section{Box 1. Internal Revenue Allocation}

\section{Legal Basis}

- Section 284 of RA No. 7160 or the Local Government Code of 1991, which provides that local government units (LGUs) shall have a $40 \%$ share from the national internal revenue tax collection of the third fiscal year preceding the current fiscal year; and Section 285, which provides the manner of allocation to the LGUs.

- Section 286 of RA No. 7160 provides that the share of each LGU shall be released without need of any further action, directly to the provincial, city, municipal, or barangay treasurer, as the case may be, on a quarterly basis within 5 days after the end of each quarter, and which shall not be subject to any lien or holdback that may be imposed by the national government for whatever purpose (actually, the the internal revenue allotment [IRA] is released comprehensively but cash allocation is released monthly, $80 \%$ of IRA share of LGUs on or before the 8 th day of the month and the remaining $20 \%$ on or before the 24 th day of every month).

- Section 4 of RA No. 9358 or the Supplemental Appropriation for FY 2006 provides that future local government share in the national internal revenue taxes or IRA shall, henceforth, be automatically appropriated.

\section{Formula or Computation}

\begin{tabular}{|cc|}
\hline LGUs & \% Allocation \\
\hline Provinces & 23 \\
Cities & 23 \\
Municipalities & 34 \\
Barangays & 20 \\
\hline Total & 100 \\
\hline
\end{tabular}

III. The distribution of shares of individual provinces, cities, and municipalities shall be made on the basis of the following formula:

\begin{tabular}{|c|c|c|c|}
\hline Factor & Percentage & Source & Document \\
\hline Population & 50 & National Statistics Office & Proclamation Order \\
\hline Land Area & 25 & Lands Management Bureau & $\begin{array}{l}\text { Official Masterlist of Land } \\
\text { Area }\end{array}$ \\
\hline Equal Sharing & 25 & & \\
\hline Total & 100 & & \\
\hline
\end{tabular}

IV. The share of each barangay is computed as follows:

- $\mathrm{P} 80,000$ for each barangay with a population of not less than 100 inhabitants.

- The balance is allocated as follows:

\begin{tabular}{|lr}
\hline Population & $60 \%$ \\
\hline Equal Sharing & $40 \%$ \\
\hline Total & $100 \%$ \\
\hline
\end{tabular}




\section{Box 1 continued}

\section{Uses of Fund}

- To fund basic services and facilities pursuant to Section 17 of the Local Government Code of 1991 particularly those which have been devolved by the national government.

- To fund development projects as identified in the LGUs' Annual Investment Plan (Section 287 of the Local Government Code of 1991 directs LGUs to set aside not less than $20 \%$ of their IRA for development projects).

Source: Department of Budget and Management, Republic of the Philippines. 2012. http://www.dbm gov.ph/ira.php

\section{Box 2. Enabling Business Environment}

$\checkmark=$ Doing Business reform making it easier to do business. $x=$ Doing Business reform making it more difficult to do business.

\section{DB2012:}

\section{$\checkmark$ Resolving Insolvency:}

The Philippines adopted a new insolvency law that provides a legal framework for liquidation and reorganization of financially distressed companies.

\section{DB2011:}

\section{$\checkmark$ Starting a Business:}

The Philippines eased business start-up by setting up a one-stop shop at the municipal level.

\section{$x$ Dealing with Construction Permits:}

The Philippines made construction permitting more cumbersome through updated electricity connection costs.

\section{$\checkmark$ Trading Across Borders:}

The Philippines reduced the time and cost to trade by improving its electronic customs systems, adding such functions as electronic payments and online submission of declarations.

\section{DB2010:}

\section{$\checkmark$ Getting Credit:}

Access to credit was enhanced with a new credit information act that regulates the operations and services of a credit information system.

\section{$\checkmark$ Paying Taxes:}

The corporate income tax rate was cut from $35 \%$ to $30 \%$ of profit.

\section{$\checkmark$ Resolving Insolvency:}

Reorganization procedures were promoted by introducing pre-packaged reorganizations and regulating the receiver profession.

\section{DB2009:}

\section{$\checkmark$ Trading Across Borders:}

The risk management and electronic data interchange system for customs was upgraded, reducing the time to import.

Source: World Bank. 2011b. Doing Business 2012 Report. Manila. http://www.doingbusiness.org/Reforms/ Overview/Economy/philippines 


\section{Business Environment}

The highlights of the Doing Business Report $2011^{27}$ for the subnational study of Philippine cities are presented below. Over the past 2 years, 13 out of 20 cities in the Philippines carried out 19 regulatory reforms to make it easier to start and operate a business.

Starting a business is easiest in General Santos, where it takes 22 days and costs $15.3 \%$ of income per capita to comply with the 17 requirements (Chart 8). It is more difficult in San Juan City, where it requires 21 procedures that take 39 days and cost $26.3 \%$.

Chart 8. Ease of Starting a Business in the Philippines

\begin{tabular}{|c|c|c|c|c|c|c|c|c|c|c|}
\hline \multirow[b]{4}{*}{ City } & \multicolumn{10}{|c|}{ Starting a Business } \\
\hline & \multirow{2}{*}{\multicolumn{2}{|c|}{$\begin{array}{c}\text { Procedures } \\
\text { (number) }\end{array}$}} & \multirow{2}{*}{\multicolumn{2}{|c|}{$\begin{array}{l}\text { Time } \\
\text { (days) }\end{array}$}} & \multicolumn{6}{|c|}{ Paid in Minimum } \\
\hline & & & & & \multicolumn{2}{|c|}{$\begin{array}{c}\text { Cost } \\
\text { (\% of GNI per } \\
\text { capita) }\end{array}$} & \multicolumn{2}{|c|}{$\begin{array}{c}\text { Capital } \\
\text { (\% of GNI per } \\
\text { capita) }\end{array}$} & \multicolumn{2}{|c|}{$\begin{array}{c}\text { Ease of Starting } \\
\text { a Business } \\
\text { (rank) }\end{array}$} \\
\hline & 2011 & 2008 & 2011 & 2008 & 2011 & 2008 & 2011 & 2008 & 2011 & 2008 \\
\hline Caloocan & 16 & 17 & 28 & 29 & 33.3 & 36.2 & 6.0 & 6.9 & 8 & 7 \\
\hline Cebu & 15 & 17 & 31 & 33 & 24.7 & 24.6 & 6.0 & 6.9 & 6 & 4 \\
\hline Davao & 17 & 24 & 27 & 43 & 17.0 & 20.7 & 6.0 & 6.9 & 1 & 17 \\
\hline Lapu-Lapu & 17 & 17 & 31 & 34 & 20.0 & 17.7 & 6.0 & 6.9 & 4 & 2 \\
\hline Las Piñas & 21 & 21 & 35 & 35 & 34.7 & 45.4 & 6.0 & 6.9 & 18 & 19 \\
\hline Makati & 19 & 19 & 33 & 33 & 36.0 & 37.9 & 6.0 & 6.9 & 16 & 12 \\
\hline Malabon & 20 & 20 & 32 & 32 & 26.7 & 31.9 & 6.0 & 6.9 & 13 & 10 \\
\hline Mandaluyong & 19 & 19 & 28 & 30 & 21.7 & 23.5 & 6.0 & 6.9 & 7 & 5 \\
\hline Mandaue & 18 & 18 & 35 & 35 & 19.9 & 22.0 & 6.0 & 6.9 & 11 & 6 \\
\hline Manila & 15 & 16 & 38 & 52 & 30.3 & 33.2 & 6.0 & 6.9 & 14 & 14 \\
\hline Marikina & 16 & 16 & 29 & 29 & 24.3 & 28.2 & 6.0 & 6.9 & 5 & 3 \\
\hline Muntinlupa & 20 & 20 & 36 & 36 & 26.9 & 26.0 & 6.0 & 6.9 & 17 & 13 \\
\hline Navotas & 21 & 21 & 34 & 34 & 21.0 & 23.1 & 6.0 & 6.9 & 12 & 9 \\
\hline Parañaque & 20 & 20 & 35 & 36 & 26.0 & 25.3 & 6.0 & 6.9 & 15 & 11 \\
\hline Pasay & 17 & 19 & 32 & 36 & 22.2 & 35.9 & 6.0 & 6.9 & 9 & 15 \\
\hline Pasig & 22 & 22 & 36 & 36 & 26.1 & 28.4 & 6.0 & 6.9 & 18 & 18 \\
\hline Quezon & 16 & 18 & 36 & 38 & 21.4 & 22.3 & 6.0 & 6.9 & 10 & 8 \\
\hline San Juan & 21 & 22 & 39 & 40 & 26.3 & 28.2 & 6.0 & 6.9 & 20 & 20 \\
\hline Taguig & 16 & 16 & 28 & 28 & 23.2 & 23.5 & 6.0 & 6.9 & 2 & 1 \\
\hline Valenzuela & 16 & 24 & 32 & 39 & 20.4 & 21.9 & 6.0 & 6.9 & 3 & 6 \\
\hline
\end{tabular}

$\mathrm{GNI}=$ gross national income.

Note: Highlighted are the top five competitive cities.

Source: World Bank. 2011b. Doing Business 2012 Report. Manila.

27 World Bank. 2011b. Doing Business 2012 Report. Manila. http://www.doingbusiness.org/Reforms/ Overview/Economy/philippines 


\section{Global Competitiveness}

The Philippines became more globally competitive by moving from position 75 to 65 worldwide in the Global Competitiveness Index Report 2012-2013 (Chart 9). The report ranks 144 economies for 150 indicators of competitiveness revolving around 12 pillars under the three sub-indices: (i) basic requirements, (ii) efficiency enhancers and innovation, and (iii) sophistication. The Philippines rose 20 places in the overall basic requirements, 23 places in institutional category, 18 places in the macroeconomic environment, 4 places in technological readiness, 9 places in goods market efficiency, 13 places in financial market development, 10 places in overall business sophistication and innovation, 7 places in higher education and training, and 1 place in market size. The country's macroeconomic environment, financial market development, market size, and business sophistication has improved the country's global competitiveness. This is partly due to the openness of the market but also largely due to private sector involvement. On the downside, the challenge lies in meeting the physical infrastructure and institutional needs while combating corruption (Chart 10).

\section{Chart 9. Global Competitive Index}

\begin{tabular}{lcc} 
Competitive Indicator & $\begin{array}{c}\text { Rank } \\
\text { (out of 144) }\end{array}$ & $(1-7)$ \\
\hline $\mathrm{GCl}$ 2012-2013 & 65 & 4.2 \\
$\mathrm{GCl}$ 2011-2012 (out of 142) & 75 & 4.1 \\
$\mathrm{GCl}$ 2010-2011 (out of 139) & 85 & 4.0 \\
\hline Basic requirements (55.5\%) & 80 & 4.3 \\
Institutions & 94 & 3.6 \\
Infrastructure & 98 & 3.2 \\
Macroeconomic environment & 36 & 5.3 \\
Health and primary education & 98 & 5.3 \\
\hline Efficiency enhancers (38.4\%) & 61 & 4.2 \\
Higher education and training & 64 & 4.3 \\
Goods market efficiency & 86 & 4.2 \\
Labor market efficiency & 103 & 4.0 \\
Financial market development & 58 & 4.3 \\
Technological readiness & 79 & 3.6 \\
Market size & 35 & 4.6 \\
\hline Innovation and sophistication factors (6.1\%) & 64 & 3.6 \\
Business sophistication & 49 & 4.2 \\
Innovation & 94 & 3.0
\end{tabular}

$\mathrm{GCl}=$ global competitive index .

Source: World Economic Forum. 2012. Global Competitiveness Index Report 2012-2013. Geneva, Switzerland. 


\section{Chart 10. Most Problematic Factors for Doing Business in Philippine Cities}

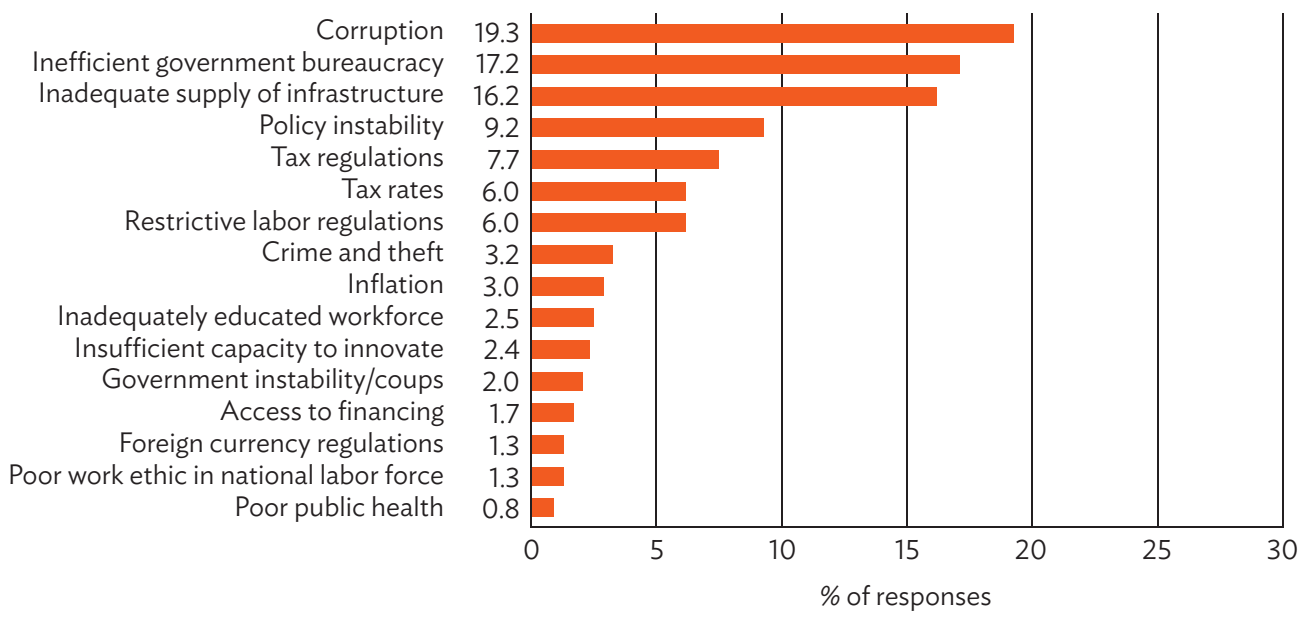

Note: From the list of factors above, respondents were asked to select the five most problematic for doing business in their country and to rank them between 1 (most problematic) and 5. The bars in the figure show the responses weighted according to their rankings.

Source: World Economic Forum. 2012. Global Competitiveness Index Report 2012-2013. Geneva, Switzerland.

\section{Competitiveness of Philippine Cities}

The competitiveness of Philippine cities in urban development can be accessed from the latest ranking of the Doing Business 2011 subnational report that ranks 25 Philippine cities using the indicator of "Ease of Dealing with Construction Permits" (Chart 11). The variables include the number of procedures required, the number of days (time) taken to process the application, and the cost (\% of gross national income per capita).

Davao City is the most competitive, having improved its ranking from seventh in 2008 to first in 2011. ${ }^{28}$ It has improved its ranking mainly by reducing the cost for processing permits. Taguig improved from fourth (2008) to second (2011). Although it increased the permit cost substantially, it reduced the processing time from 121 days to 85 days.

The other indicator of urban competitiveness in the study was the "Ease of Registering Property" (Chart 12). It is easiest to register property in Valenzuela and Navotas and more difficult in the cities of Cagayan de Oro and General Santos. The differences are mainly driven by the performance of national government agencies.

28 For comparability of 2008 and 2011 data, the table records only the cities benchmarked in both the Doing Business in the Philippines 2008 and Doing Business in the Philippines 2011 reports. Tanauan, measured in 2008 but not in 2011, is not taken into account. Batangas City, Cagayan de Oro City, General Santos City, lloilo City, and Zamboanga City, were added in 2011 and are also not taken into account. 
Chart 11. Ease of Dealing with Construction Permits in Philippine Cities

\begin{tabular}{|c|c|c|c|c|c|c|c|c|}
\hline \multirow[b]{3}{*}{ City } & \multicolumn{8}{|c|}{ Dealing with Construction Permits } \\
\hline & \multicolumn{2}{|c|}{$\begin{array}{l}\text { Procedures } \\
\text { (number) }\end{array}$} & \multicolumn{2}{|c|}{$\begin{array}{l}\text { Time } \\
\text { (days) }\end{array}$} & \multicolumn{2}{|c|}{$\begin{array}{c}\text { Cost } \\
\text { (\% of GNI per capita) }\end{array}$} & \multicolumn{2}{|c|}{$\begin{array}{c}\text { Ease of Dealing with } \\
\text { Construction Permits } \\
\text { (rank) }\end{array}$} \\
\hline & 2011 & 2008 & 2011 & 2008 & 2011 & 2008 & 2011 & 2008 \\
\hline Caloocan & 31 & 30 & 109 & 136 & 791.8 & 132.2 & 12 & 8 \\
\hline Cebu & 36 & 35 & 92 & 85 & 126.4 & 476.8 & 10 & 15 \\
\hline Davao & 27 & 29 & 57 & 59 & 94.2 & 464.3 & 1 & 7 \\
\hline Lapu-Lapu & 34 & 33 & 88 & 89 & 529.3 & 557.8 & 6 & 15 \\
\hline Las Piñas & 27 & 26 & 102 & 133 & 796.9 & 104.3 & 6 & 3 \\
\hline Makati & 26 & 26 & 90 & 125 & 806.6 & 102.4 & 8 & 1 \\
\hline Malabon & 32 & 32 & 112 & 156 & 815.3 & 146.1 & 18 & 18 \\
\hline Mandaluyong & 33 & 31 & 121 & 154 & 794.9 & 136.3 & 16 & 12 \\
\hline Mandaue & 35 & 34 & 72 & 69 & 135.5 & 480.6 & 5 & 14 \\
\hline Manila & 26 & 24 & 169 & 203 & 778.5 & 102.4 & 9 & 6 \\
\hline Marikina & 28 & 27 & 91 & 121 & 785.2 & 123.2 & 3 & 2 \\
\hline Muntinlupa & 31 & 32 & 108 & 141 & 802.1 & 127.2 & 13 & 10 \\
\hline Navotas & 28 & 29 & 107 & 145 & 802.6 & 142.9 & 11 & 12 \\
\hline Parañaque & 30 & 31 & 107 & 137 & 827.3 & 137.3 & 15 & 11 \\
\hline Pasay & 31 & 31 & 121 & 164 & 798.4 & 141.2 & 14 & 17 \\
\hline Pasig & 36 & 36 & 148 & 174 & 790.8 & 127.9 & 18 & 18 \\
\hline Quezon & 33 & 32 & 120 & 140 & 804.4 & 123.7 & 17 & 9 \\
\hline San Juan & 33 & 33 & 144 & 175 & 804.7 & 135.0 & 20 & 18 \\
\hline Taguig & 25 & 25 & 85 & 121 & 795.3 & 136.4 & 2 & 4 \\
\hline Valenzuela & 28 & 27 & 91 & 123 & 789.8 & 129.2 & 4 & 5 \\
\hline
\end{tabular}

$\mathrm{GNI}=$ gross national income.

Note: Highlighted are the top five competitive cities.

Source: World Bank. 2011b. Doing Business 2012 Report. Manila.

\section{Competitive Base: Economic Profile}

The Philippines is a lower-middle-income country with a gross domestic product (GDP) per capita of $\$ 2,007$ in 2010. A combination of the global financial crisis, global food and fuel hikes, and natural disasters slowed GDP growth to 3.8\% in 2008 and $1.1 \%$ in 2009. The Philippine economy strongly rebounded in 2010 with an average GDP growth of $7.6 \%$ driven by a recovery in investment and exports, a real estate construction boom, and robust private consumption backed by remittance inflows.

However, GDP growth dropped to 3.9\% in 2011 mainly due to a decline in exports from the middle of 2011, and secondly, due to decreased public infrastructure spending. ${ }^{29}$ Economic

29 ADB. 2011m. Prospects for the Philippines. Speech delivered by V.P. Groff to the Foreign Correspondents Association, 19 January, Manila. 
Chart 12. Ease of Registering Property in Philippine Cities

\begin{tabular}{|c|c|c|c|c|c|c|c|c|}
\hline \multirow[b]{3}{*}{ City } & \multicolumn{8}{|c|}{ Registering Property } \\
\hline & \multicolumn{2}{|c|}{$\begin{array}{l}\text { Procedures } \\
\text { (number) }\end{array}$} & \multicolumn{2}{|c|}{$\begin{array}{l}\text { Time } \\
\text { (days) }\end{array}$} & \multicolumn{2}{|c|}{$\begin{array}{c}\text { Cost } \\
\text { (\% of GNI per capita) }\end{array}$} & \multicolumn{2}{|c|}{$\begin{array}{c}\text { Ease of Registering } \\
\text { Property } \\
\text { (rank) }\end{array}$} \\
\hline & 2011 & 2008 & 2011 & 2008 & 2011 & 2008 & 2011 & 2008 \\
\hline Caloocan & 8 & 8 & 33 & 32 & 3.8 & 4.8 & 7 & 15 \\
\hline Cebu & 9 & 9 & 24 & 32 & 3.6 & 3.5 & 4 & 12 \\
\hline Davao & 8 & 8 & 36 & 33 & 4.9 & 4.8 & 20 & 16 \\
\hline Lapu-Lapu & 8 & 8 & 64 & 41 & 3.8 & 3.7 & 11 & 10 \\
\hline Las Piñas & 8 & 8 & 30 & 25 & 4.7 & 4.5 & 6 & 3 \\
\hline Makati & 9 & 9 & 32 & 33 & 4.7 & 4.6 & 19 & 20 \\
\hline Malabon & 9 & 9 & 32 & 32 & 3.6 & 4.5 & 13 & 18 \\
\hline Mandaluyong & 9 & 9 & 22 & 22 & 4.8 & 4.5 & 17 & 7 \\
\hline Mandaue & 8 & 8 & 63 & 43 & 3.3 & 3.3 & 5 & 8 \\
\hline Manila & 8 & 8 & 33 & 33 & 4.3 & 4.2 & 9 & 5 \\
\hline Marikina & 8 & 8 & 32 & 32 & 4.8 & 4.7 & 12 & 14 \\
\hline Muntinlupa & 9 & 9 & 27 & 27 & 4.8 & 4.5 & 16 & 9 \\
\hline Navotas & 8 & 8 & 32 & 30 & 3.5 & 4.5 & 2 & 4 \\
\hline Parañaque & 9 & 9 & 27 & 27 & 4.6 & 4.5 & 13 & 11 \\
\hline Pasay & 8 & 9 & 31 & 32 & 4.9 & 4.7 & 15 & 19 \\
\hline Pasig & 8 & 8 & 30 & 30 & 4.6 & 4.5 & 3 & 2 \\
\hline Quezon & 8 & 8 & 39 & 39 & 4.8 & 4.7 & 18 & 17 \\
\hline San Juan & 9 & 9 & 26 & 26 & 4.6 & 4.5 & 10 & 13 \\
\hline Taguig & 8 & 8 & 32 & 31 & 4.6 & 4.5 & 7 & 6 \\
\hline Valenzuela & 8 & 8 & 30 & 30 & 3.5 & 4.5 & 1 & 1 \\
\hline
\end{tabular}

$\mathrm{GNI}=$ gross national income.

Note: Highlighted are the top five competitive cities.

Source: World Bank. 2011b. Doing Business 2012 Report. Manila.

growth rebounded strongly to $6.4 \%$ in the first quarter of 2012, assisted by a recovery in public spending and net exports.

The external environment remains a key risk to growth as is evident from sustained weakness in electronic exports and deceleration in the growth of remittances from overseas Filipino workers. The fiscal deficit is tracking the government's medium-term target and reflects the government's improving fiscal performance. National government debt continues to be sustainable, falling to $49.5 \%$ in proportion to GDP as of the end of June 2013. The June figures indicate an improvement from the end of December 2012 when the ratio stood at $51.5 \% .{ }^{30}$ The current account balance remains in surplus. Inflation has remained modest and within

30 Bureau of the Treasury. 2013. National Government Debt Remains Sustainable as of end-June 2013. Press release. 29 August. http://www.treasury.gov.ph/news/news/NGDebtJune2013-press\%20release $\% 20$ revised.pdf 
the central bank's target range. The government has kept the momentum for governance reforms, improving the environment for private investment. These reforms and recent upgrades in the sovereign credit rating should reduce real long-term interest rates and help increase the medium-term growth potential. Higher government revenues remain crucial to fund the social development and infrastructure programs required to reduce poverty, and lay the foundation for a targeted sustained and inclusive growth of 7\%-8\% per annum. ${ }^{31}$

A shift from the agriculture sector to the service sector began in 2000, marked by an increase in GDP contribution by the service sector from 43.6\% in 1990 to $55.1 \%$ in 2010, while the agriculture sector share declined from $21.9 \%$ to $12.3 \%$ over the same period. Employment in the service sector increased nationwide from $46.0 \%$ in 1995 to $52.5 \%$ in 2000 , steadily increasing to $57.9 \%$ in 2010 . The share of employment in industry showed a marginal decrease from $10.6 \%$ in 1995 to $9.0 \%$ in 2010 , while the total agricultural labor force declined markedly from $44.9 \%$ to $33.2 \%$ over the same period.

This trend was reinforced with the increase in foreign direct investment in manufacturing (mainly electronics), and in the service sector with business process outsourcing activities (primarily call centers). However, lack of diversity in the export sector in manufacturing makes the economy vulnerable to fluctuations in the global economy (Chart 13).

The service sector industry, has been progressively moving from business process outsourcing to knowledge process outsourcing businesses like financial services, accounting

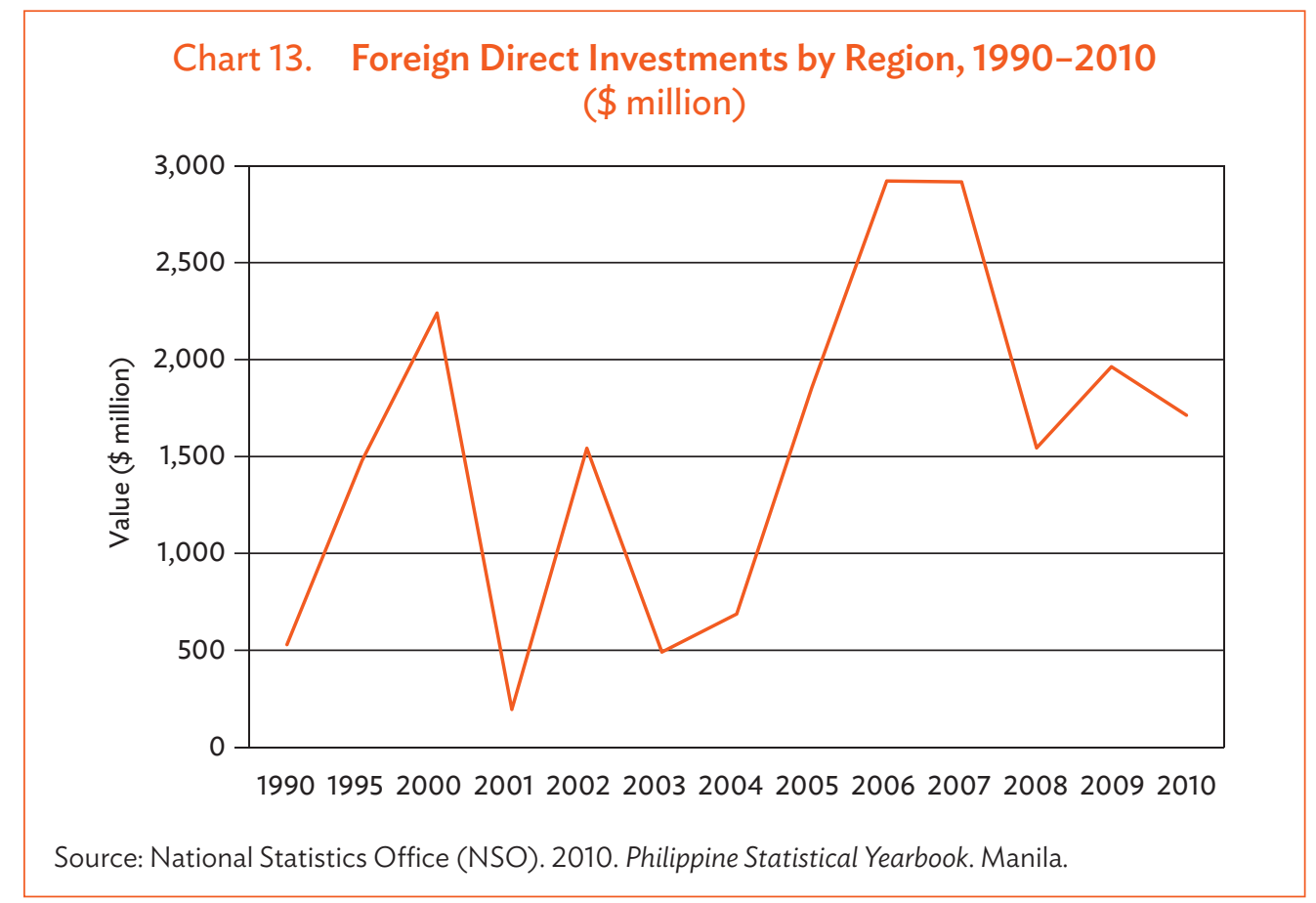

31 ADB. 2012b. Country Operations Business Plan: Philippines, 2013-2015. Manila. 
services, medical transcriptions, and software development. These urban-based activities stimulate urban development, particularly the construction industry, with commercial and housing developments in the major urban centers. Leading the change in the Philippines KPO industry are financial giants such as Citibank, Deutsche Bank and JP Morgan Chase. ${ }^{32}$

Consequently, urban areas generate more than $85 \%$ of the GDP, higher than other countries in Asia where urban areas generate between 65\% and 75\%.3 The NCR leads economic growth across the regions (Chart 14). Since 2000, there has been a sharp increase in NCR GDP attributable to the development of the service sector. Metro Manila alone accounts for 33\% of the GDP. Meanwhile, four metropolitan areas (Batangas, Iloilo, Cebu, and Davao) are located in regions with a relatively high GDP share. The lagging regions, besides ARMM and CAR, are Regions XIII, II, IV-B, VIII, and Region IX. The high disparity between the NCR and the lagging regions needs to be bridged through sustainable investments in these regions.

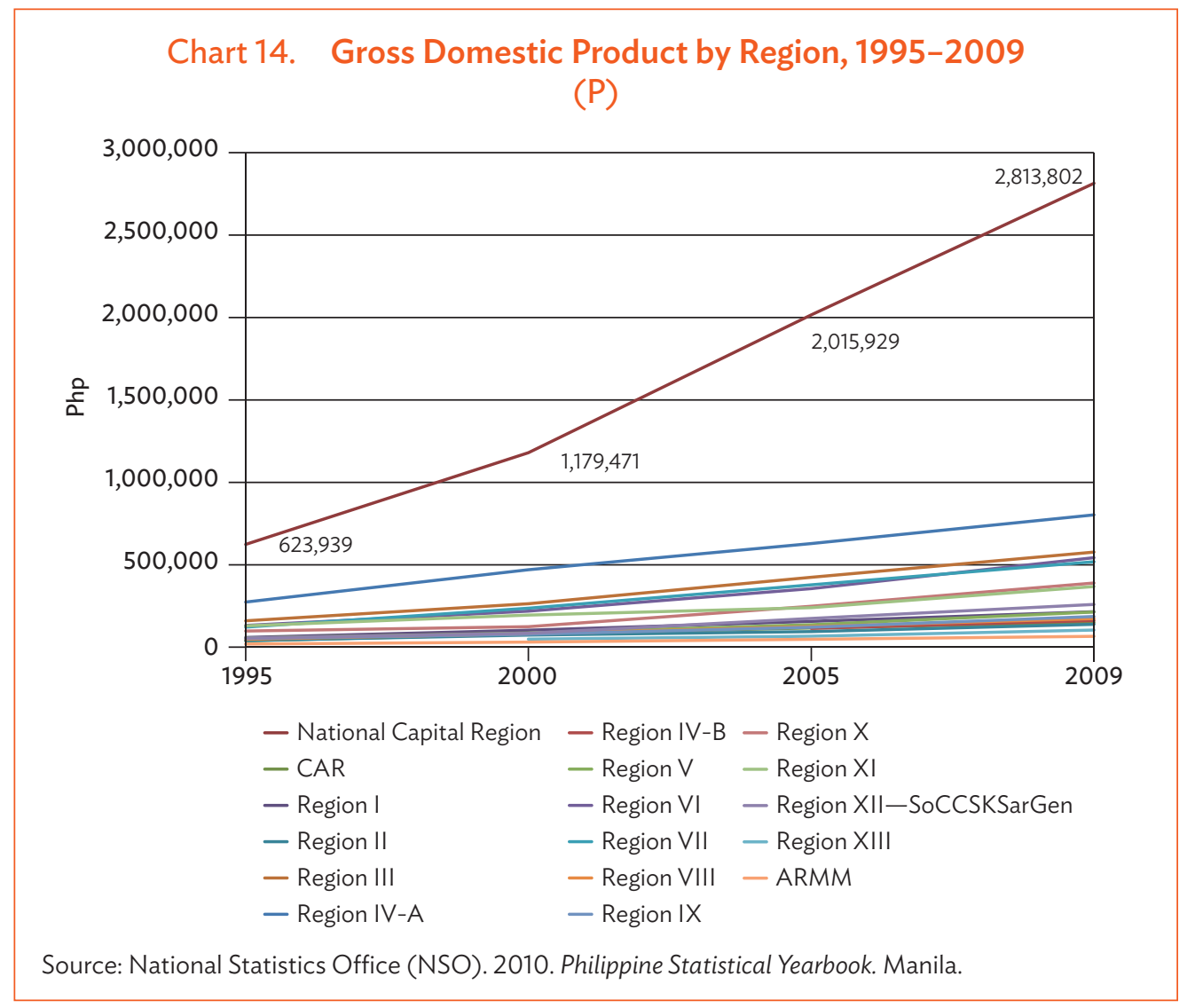

32 Manabat Sanaugustin \& Co. CPAs and KPMG 2011. The Philippines - Outsourcing's new destination. A Guide for Businessmen and Investors. http://www.kpmg.com/PH/en/PHConnect/ArticlesAndPublications/ Documents/The\%20Philippines-\%200utsourcing's\%20new\%20destination--\%20Guide\%20for\%20 Businessmen\%20and\%20Investors\%202011-2012\%20Digital\%20Edition.pdf

33 HUDCC. 2009. National Urban Development and Housing Framework (NUDHF) 2009-2016. Manila. 
Employment creation through development of a stronger industrial base in these regions can induce inclusive economic growth by spatially distributing economic activity while ensuring spatial linkage between centers of production, processing, and distribution. ${ }^{34}$ Small and medium-sized enterprises (SMEs) dominate the Philippine economy, accounting for $99.6 \%$ of all registered firms nationwide and $70 \%$ of jobs. ${ }^{35}$ Small volumes of credit financing and low rates for disbursement of funds limit credit utilization and act as constraints for SME development.

With more tourists arriving in the Philippines exposed to the service industry, strategic investments in cross-sector initiatives such as health tourism and cultural tourism could be pursued alongside alternative livelihood opportunities by natural-resource-dependent communities to promote sustainable growth (Chart 15). Investment in transport infrastructure to improve access to geographically dispersed regions could prove timely in promoting tourism and improving economic prospects.

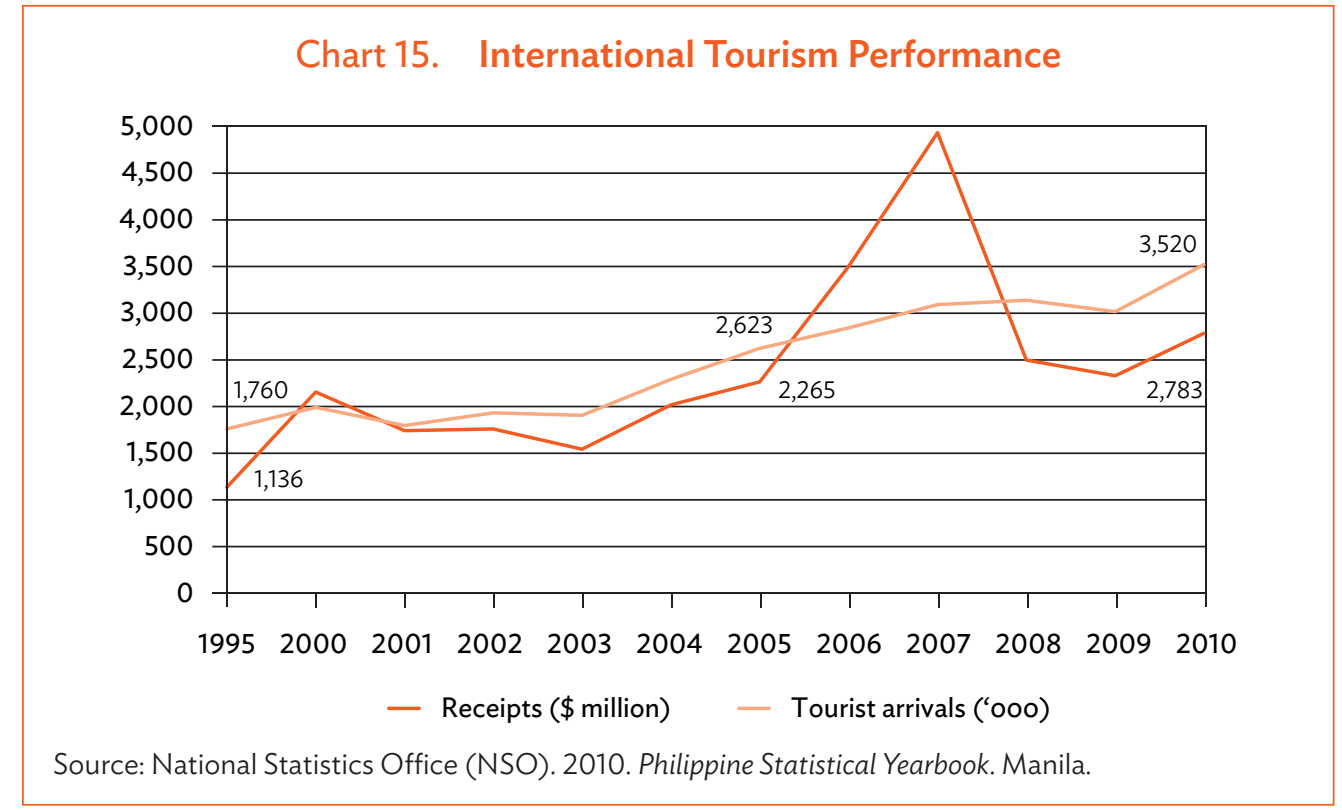

\section{Inclusive Base: Equity Profile}

The Philippines is a lower-middle-income country, historically characterized by uneven distribution of assets and unequal access to opportunities, resulting in one of the highest income inequalities in the region. Intra-urban inequities in Philippine cities are high. As a result, the country's income distribution is the most unequal in Asia, its Gini coefficient

\footnotetext{
Footnote 21.

Footnote 33 .
} 
being $0.45^{36}$ (Chart 16). The country's rate of poverty incidence was $26.5 \%$ in 2009, up from $24.9 \%$ in 2003 , which underscores the fact that progress in poverty reduction in the Philippines is more modest than in other Southeast Asian countries. This is in part due to the country's slower pace of per capita economic growth compared with other Southeast Asian countries, and its rate of population growth, which was the highest in Southeast Asia from 2005 to 2010.

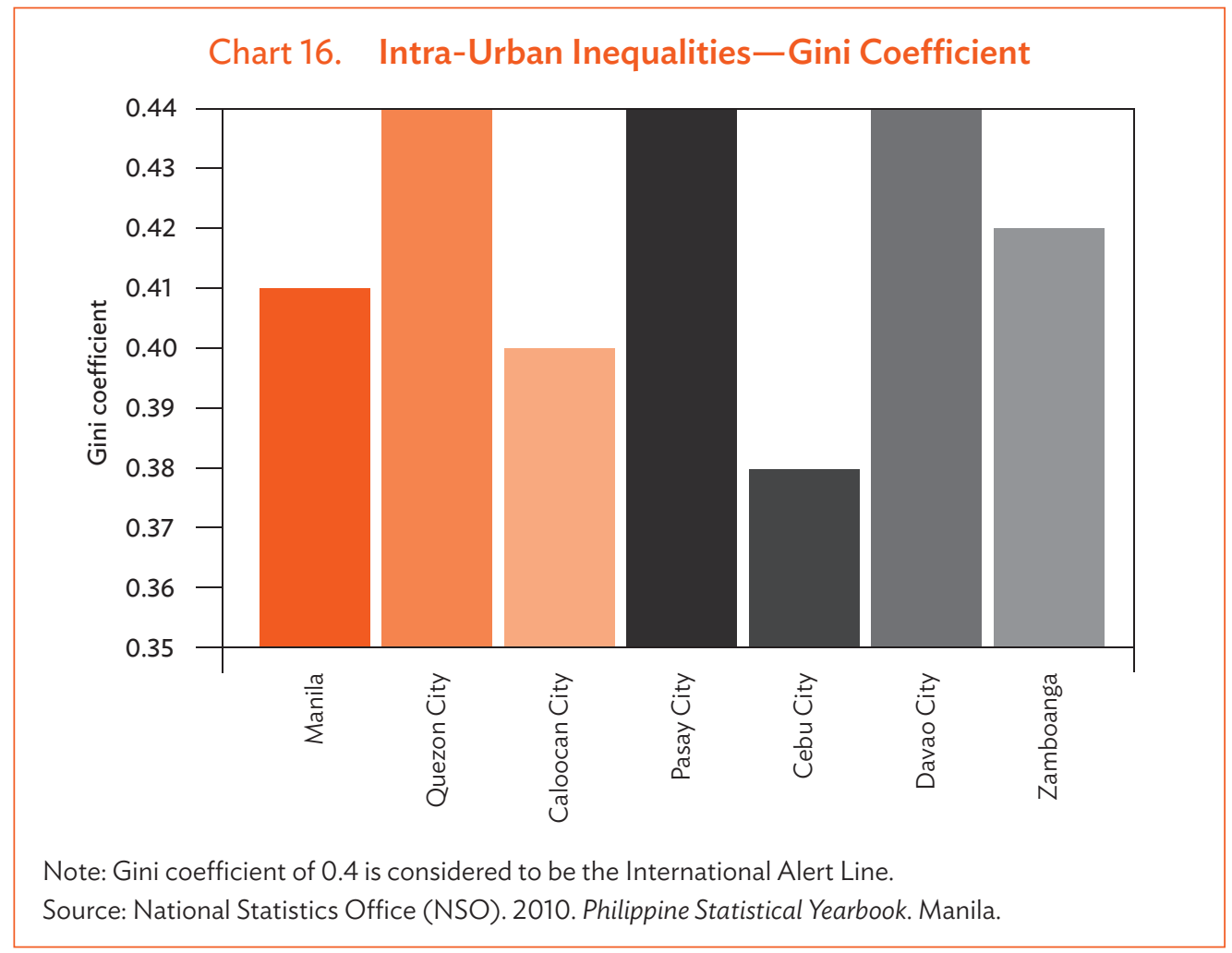

Yet the relationship between economic growth and poverty reduction has been weak. Economic growth has been unable to provide sustainable employment for low-income and vulnerable groups. Service sector opportunities are characteristically skill oriented and inadvertently increase the inequality of access to disadvantaged groups. Greater effort is required to link educational attainment, vocational training, and skills development to employment creation in the manufacturing and industry sector to reduce regional disparities and promote inclusive growth.

The Philippines' Gender Inequality Index score, which measures gender disadvantage across reproductive health, empowerment, and the labor market, was 0.42 in 2012, indicating the need to address gender equity in these areas. ${ }^{37}$

36 ADB.2012c. Confronting Rising Inequality in Asia. Asian Development Outlook 2012. Manila. http:// www.adb.org/sites/default/files/ado2012-phi.pdf

37 Footnote 5. 


\section{Employment}

Unemployment rates have been declining since 2003. At $12.8 \%$, the NCR displays a higher unemployment rate than the national average of $7.4 \%$ (Chart 17). Progress in reducing unemployment is hampered by the fact that the pace of economic growth has been insufficient to absorb all new labor force entrants from low-income and vulnerable groups. As mentioned above, the bulk of employment growth in recent years has occurred in the skill-intensive service sector. While this is, overall, a welcome development, it has exacerbated income and employment inequalities, thus negatively impacting the country's disadvantaged groups.

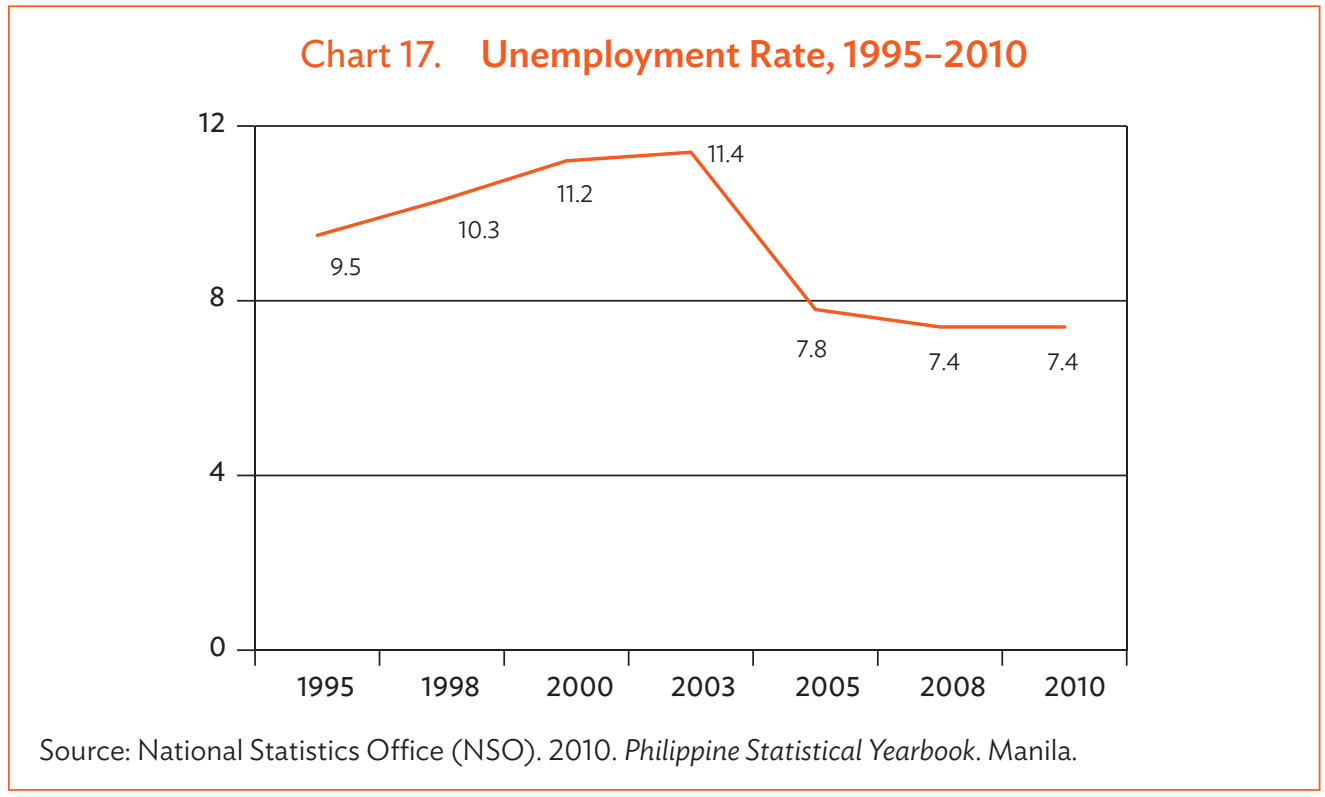

An ADB report, analyzing gender equality in the labor market and related policies and legislation in the Philippines, concluded with recommendations to promote gender equality. ${ }^{38}$ Despite high levels of human capital, women's labor force participation rate is much lower than men's, even compared to other Southeast Asian countries. In the Philippines, the employment gap between women and men is $26 \%$. Furthermore, women's annual earnings are only an estimated $60 \%$ of men's. There is little evidence of improvement given that the share of women in waged employment in the nonagriculture sector rose only from $40.9 \%$ to $41.8 \%$ from 2000 to 2011 . Hence, it is not surprising that $60 \%$ of overseas Filipino workers were women in 2009. In recent years, there has been increasing concern over the safety of overseas Filipinas, particularly those working in unprotected sectors such as domestic service and entertainment in global urban centers. The Philippines will have to strengthen support for overseas female workers particularly in the context of genderbased violence.

38 Footnote 5. 
Challenges remain even with substantial progress in promoting gender equality and inclusive growth in the labor market. Challenges for women in the labor market include (i) unpaid domestic work and care burden; (ii) limited access to resources, including credit and financial services; (iii) inadequate education and lack of training programs; (iv) access to government services; (v) disadvantages in social protection coverage; and (vi) pervading discrimination. Despite economic and employment growth, gendered employment indicators suggest that gender equality in the labor market remains a goal rather than a realized objective.

Urban poverty is on the rise though two-thirds of the poor still live in rural areas. Rural poverty incidence continues to be higher than the national average (32.9\% in 2006), while urban poverty incidence has steadily declined with the lowest rate (10.4\% in 2006) for NCR, the most urbanized region. Yet the absolute number of poor continues to rise. Furthermore, a large portion of the urban population lives barely above the poverty line, and these individuals are vulnerable to slipping back below it due to loss of employment, illness, natural disasters, or other factors affecting income levels.

Similarly, while the share of the urban population living in informal settlements declined from $54.3 \%$ in 1990 to $43.7 \%$ in 2009 , the absolute number of inhabitants living in such settlements has steadily increased indicating a need to address urban renewal through targeted investments (Chart 18). The fact that informal settlements typically expand in undesirable locations such as in areas fronting railways and on riverbanks makes providing access to basic urban services in these settlements problematic, though access to such services in informal settlements has tended to improve over time.

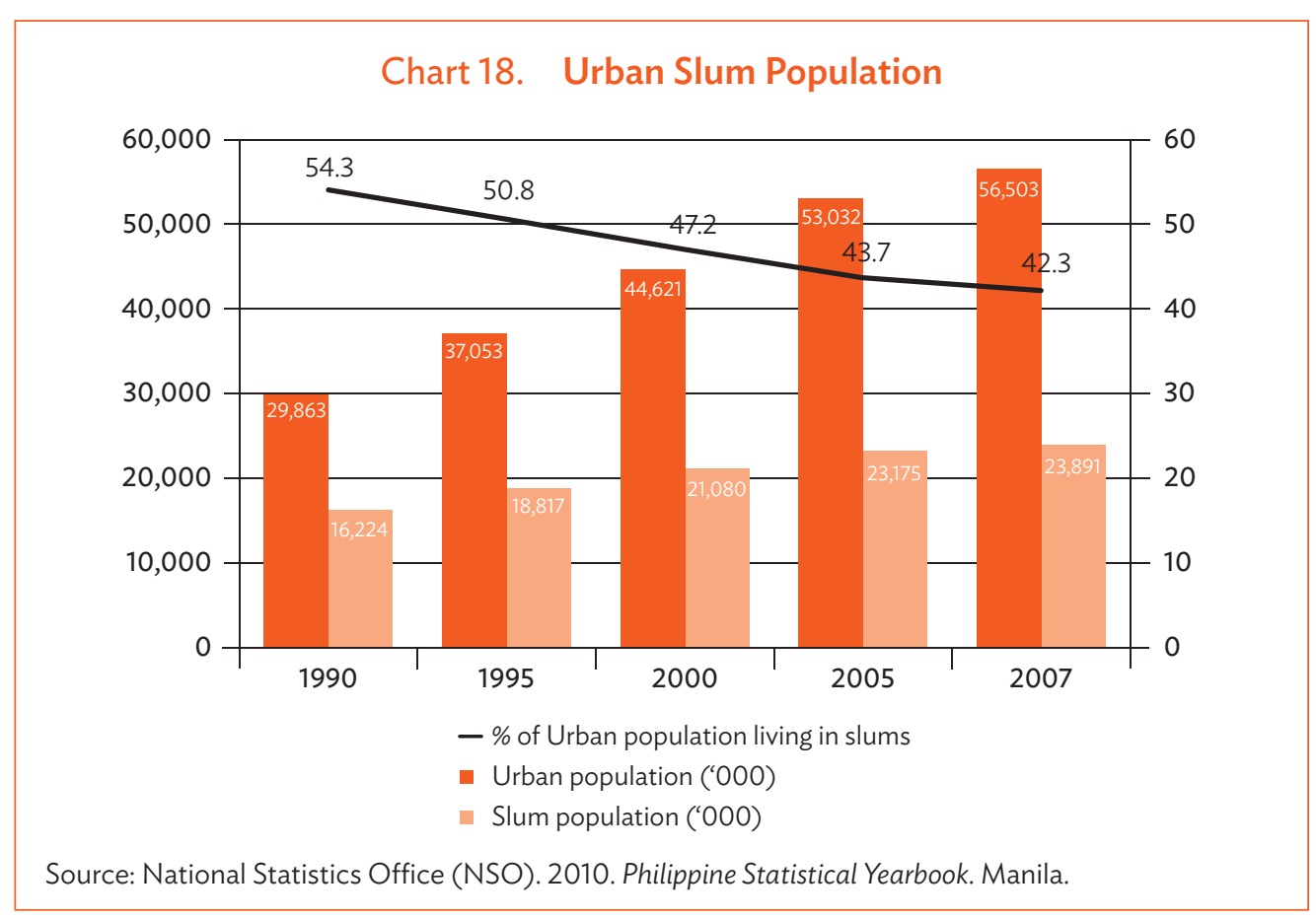




\section{Green Base: Environmental Profile}

\section{Climate Change}

The impact of climate change on mean and extreme precipitation rates is an area of concern for planning. Modeling 50 years into the future, a time-series-based analytic model formulated by the United Kingdom Climate Research Unit showed two key results for the Philippines: (i) an increase in June-August precipitation under all scenarios, and (ii) a decrease in December-February precipitation under the high carbon dioxide $\left(\mathrm{CO}_{2}\right)$ emission scenario. How these changes might affect the wet and dry seasons in the country is still to be studied. There seems to be a general consensus among climatologists that over time, climate change will heighten the severity of droughts and deluges ${ }^{39} \mathrm{~A}$ challenge will be scaling relevant global data on climate change down to the city and municipality level, and translating this data to the sector level. A further challenge will be compiling a comprehensive and meaningful information database. A report such as the Philippine Environment Monitor, ${ }^{40}$ which presents a snapshot of key environmental trends in the county, for example, could be a good tool for monitoring and reporting this comprehensively, including data related to the health of the environment and water degradation. ${ }^{41}$

\section{Vulnerability}

Many of Asia's largest cities located on or close to coastal areas will be heavily affected by rising sea levels and violent weather (Map 3). The Philippines ranks third globally in combined disaster risk exposure and vulnerability, the annual direct damage cost of natural disasters in the Philippines over the period 1990 to 2008 varied between $0.7 \%$ and $1.0 \%$ of GDP. ${ }^{42}$ Degradation of the natural resources base due to overuse, inadequate livelihood opportunities in natural-resource-dependent communities, and high population densities along coastlines exposed to natural disasters have caused significant environmental degradation that is further exacerbated by climate change. Most urban settlements are along the coastline, exposing them to climate change impacts and natural disasters.

Manila, with nearly 12 million inhabitants, is the largest urban agglomeration in the world and is at high risk from cyclones, floods, and earthquakes. Four other large coastal cities in Asia are at a similarly high risk, including Davao, which is potentially exposed to the risks of cyclones, floods, and earthquakes. ${ }^{43}$ Tropical storm Ondoy (international name Ketsana) hit the Philippines on 26 September 2009, causing widespread flooding. Ondoy was quickly followed by typhoon Pepeng (international name Parma). It initially brought powerful winds with gusts of up to 230 kilometers per hour then an extended period of heavy rains, with cumulative rainfall amounts exceeding 1,000 millimeters in some areas. The resulting river

39 Manila Observatory for the Congressional Commission on Science \& Technology and Engineering. 2010. Technical Primer on Climate Change. Manila.

40 World Bank. 2007. Philippines Environment Monitor 2006. Washington, DC.

41 ADB. 2012d. Philippines: Water Supply and Sanitation Sector Assessment, Strategy, and Road Map. Manila.

42 ADB. 2011i. Thematic Assessment: Climate Change and Disaster Risk Reduction. Country Partnership Strategy: Philippines, 2011-2016. Manila.

43 United Nations, Department of Economic and Social Affairs, Population Division. 2012. World Urbanization Prospects: The 2011 Revision. New York. 


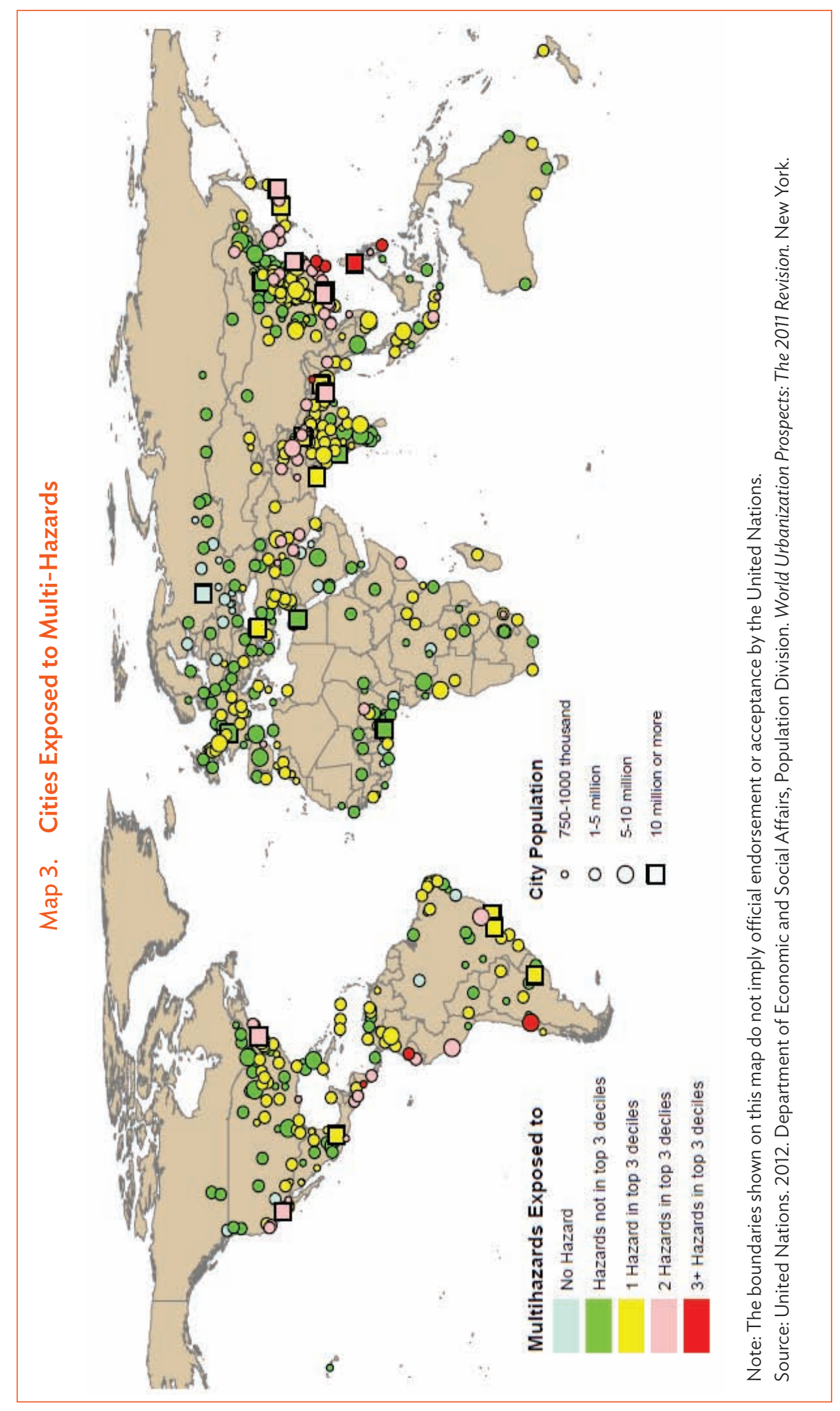


floods have been estimated to have a return period of around 50 years, meaning that such a rainfall event occurs, on average, once every 50 years. Ondoy and Pepeng resulted in large numbers of affected persons and casualties, almost 4.9 million families nationwide, $56 \%$ of which were in the NCR (1.4 million) ${ }^{44}$

Metro Manila sits on a flood plain of three rivers: the Marikina, the Napindan, and the Pasig. In August 2012, this flood plain experienced severe flooding, as monsoon rains swelled rivers and creeks and overwhelmed drainage canals already clogged with rubbish. The Department of Public Works and Highways (DPWH) had announced a master plan for effective and comprehensive flood management in Metro Manila up to the year 2035 that was to reduce the vulnerability of Metro Manila and outlying provinces to flooding during heavy rains.

\section{Urban Environmental Challenges}

Nonnatural-disaster-related environmental challenges in urban areas include recurrent flooding, traffic congestion, air pollution, water pollution, sea-level rise, and land subsidence. Encroachment along riverbanks and fragile coastal areas, lack of appropriate sewage disposal facilities, inadequate sewerage connections, and improper waste disposal all cause environmental degradation of the country's waterways, increasing potential health risks to residents. Similarly, the deficit in urban infrastructure facilities further aggravates the vulnerability of coastal settlements to flash flooding caused by upland deforestation and soil erosion. Water supply, sanitation, flood control, and solid waste management (SWM) systems are generally inefficient and inadequate for the demand. As a result, the country's urban sector requires continued assistance in upgrading infrastructure facilities. ${ }^{45}$

\section{Greenhouse Gas Emissions}

The Philippines was ranked 39th in the world in 2005 in terms of overall greenhouse gas (GHG) emissions, with about 142 million tons of carbon dioxide equivalent $\left(\mathrm{MtCO}_{2} \mathrm{e}\right)$, excluding emissions due to land use change ${ }^{46}$ (Chart 19). Based on the trend in emission growth, policy conditions affecting primary energy supply and demand, and estimated abatement costs, the GHG emission reduction priorities should be in the power and transport

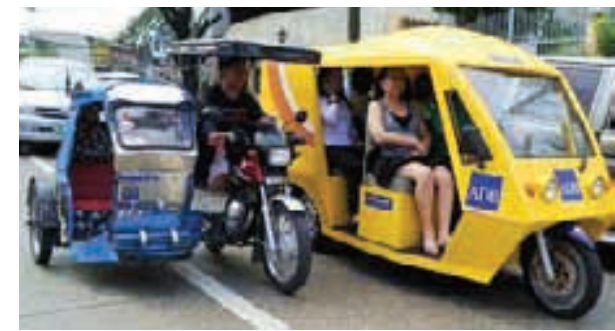
sectors, which account for $36 \%$ and $32 \%$, respectively, of total energy $\mathrm{CO}_{2}$ emissions (Chart 20).

The transport sector, with 3.5 million registered motorcycles and tricycles, releases 10 million tons of $\mathrm{CO}_{2}$ and consumes close to $\$ 3$ billion worth of fuel per year. Introduction of new transport technologies, like the e-jeepneys, is an option to mitigate transport emissions.

44 World Bank. 2011c. Executive Summary. In Philippines-Typhoons Ondoy and Pepeng: Post-Disaster Needs Assessment. Vol. I. Washington, DC. http://documents.worldbank.org/curated/en/2011/01/15115760/ philippines-typhoons-ondoy-pepeng-post-disaster-needs-assessment-vol-1-3-executive-summary

45 ADB. 2011j. Thematic Assessment (Summary): Water Supply and Other Municipal Infrastructure and Services. Country Partnership Strategy: Philippines, 2011-2016. Manila.

46 World Bank. 2010. A Strategic Approach to Climate Change in the Philippines. Final Report. Washington, DC. 


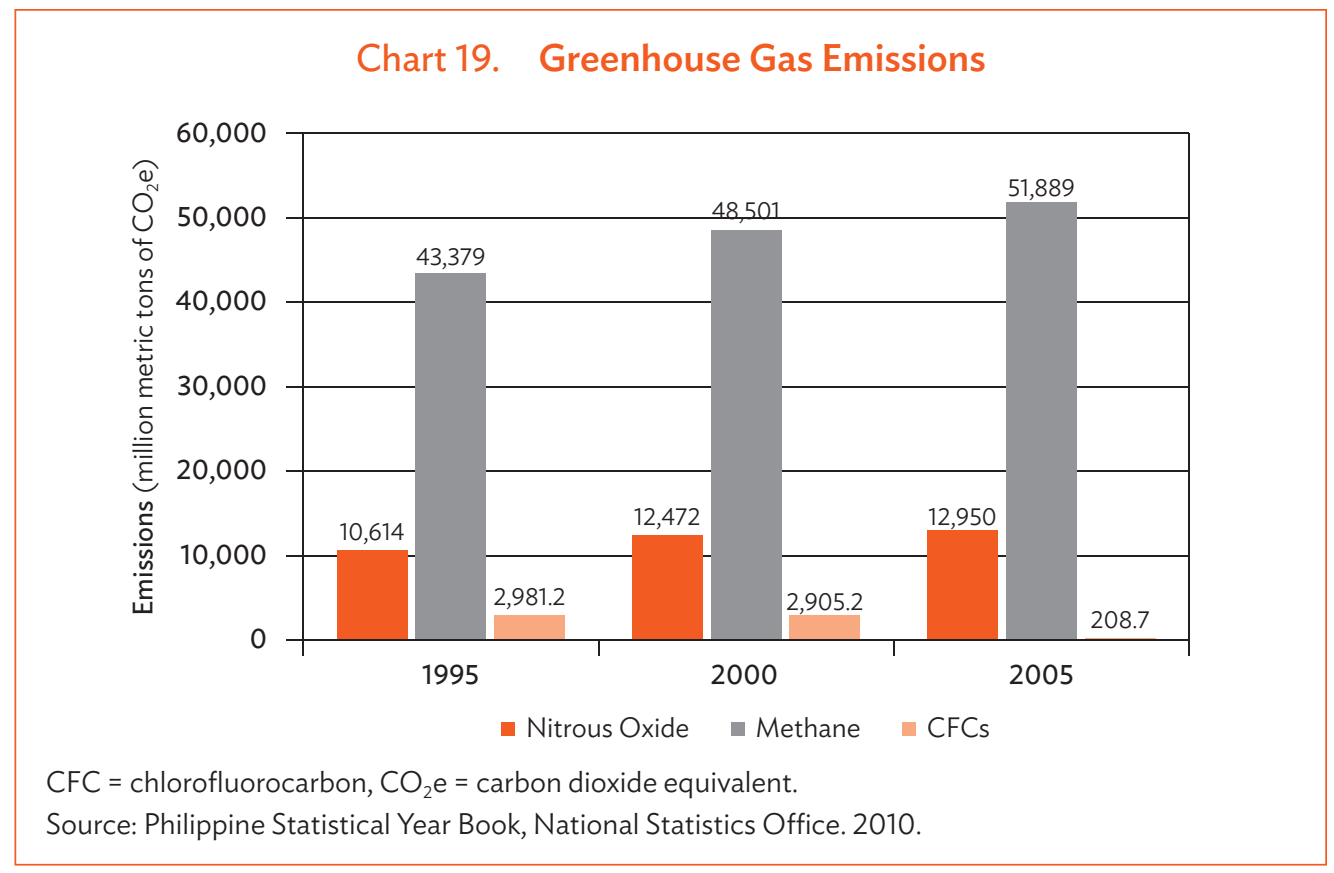

\section{Chart 20. Carbon Dioxide Emissions in Transport and Power Sectors}

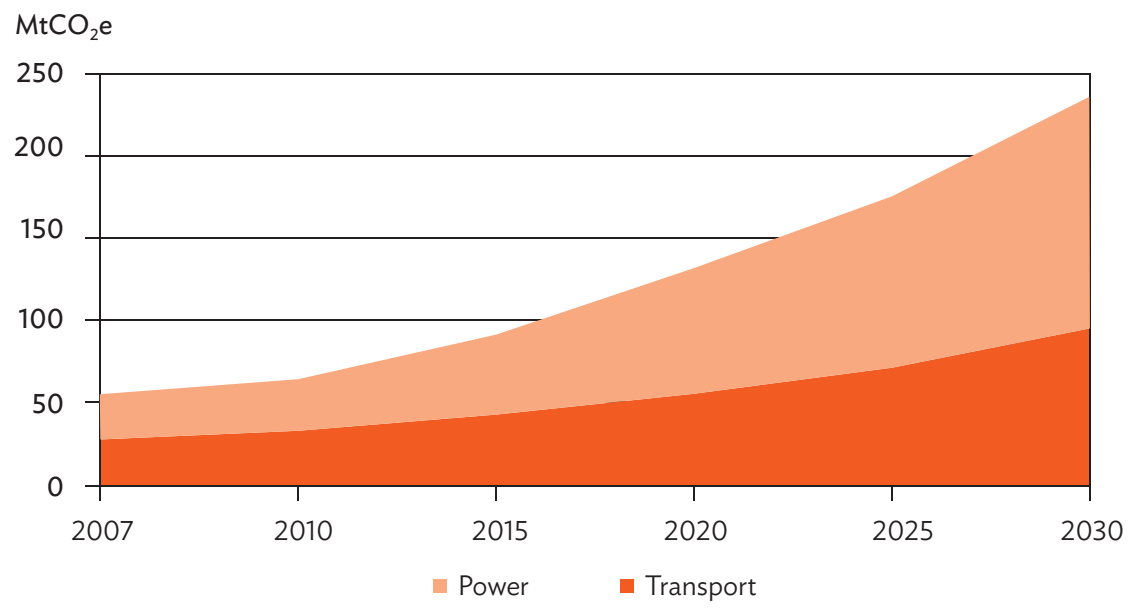

$\mathrm{MtCO}_{2} \mathrm{e}=$ million tons of carbon dioxide equivalent.

Source: National Statistics Office (NSO). 2010. Philippine Statistical Yearbook. Manila. 


\title{
ADB and Development Partner Support in Urban Development
}

\section{ADB Urban Operations}

\begin{abstract}
ADB's country partnership strategy (CPS), 2011-2016 for the Philippines aims to help the government achieve high, inclusive, and sustainable growth. The Philippines is a founding member of ADB, its 11th largest shareholder and the ADB host country. It is the fifth largest borrower in cumulative loan amounts, accounting for about $8 \%$ of total sovereign lending. In terms of cumulative nonsovereign financing, the Philippines is the fifth largest client with $6.3 \%$ of ADB total nonsovereign operations. Since 1966, the Philippines has received $\$ 14.41$ billion in sovereign and nonsovereign loans, $\$ 266.15$ million in technical assistance, and $\$ 75.61$ million in grants. ${ }^{47}$ Total ADB lending for urban projects that support the development of the urban and local government sectors amounted to $\$ 1.18$ billion from 1973 to 2008 , of which $\$ 23$ million was in the form of technical assistance (TA). Multilateral and bilateral assistance included TA loans, sector investment loans, specific investments, and TA grants. On capacity development, there has been a steady stream of TA and institutional strengthening programs

ADB Finance for Urban Projects in the Philippines (Cumulative 1973-2008)

$\begin{array}{lr}\text { Urban loans (1974-2003) (\$) } & 1,157,130,000 \\ \text { Urban technical assistance } & \\ (1973-2008)(\$) & 23,097,700 \\ \text { TOTAL }(\$) & 1,180,227,700\end{array}$
\end{abstract}
channeled into urban infrastructure and basic services.

In 2011, ADB and the Government of the Philippines agreed on a new CPS, from 2011 to 2016 for the Philippines aimed at high, inclusive, and sustainable growth. ${ }^{48}$ The strategic thrust of the CPS is consistent with the Philippine Development Plan, 2011-2016 and includes (i) improved investment climate and private sector development; (ii) more efficient, effective, and equitable social services delivery; (iii) reduced environmental degradation and vulnerability to climate change and disasters; and (iv) strengthened governance and reduced corruption. The CPS targets governance reforms and measures to drive broadbased growth and poverty reduction efforts. The country operations business plan (COBP), 2013-2015 is aligned with the CPS and takes into account government priorities, the ADB Strategy 2020, and lessons learned from program implementation. ${ }^{49}$ Preparation of the COBP was closely coordinated with development partners in the spirit of harmonization. The program amounts to $\$ 3.8$ billion for the 6-year period.

\section{Lessons Learned from Urban Operations}

Since 1974, ADB assistance in the sector has totaled $\$ 743.5$ million. This includes 20 loans totaling $\$ 731.0$ million, and 25 TA initiatives with a total value of $\$ 12.4$ million. In addition,

ADB 2014. Philippines Fact Sheet. Manila http://www.adb.org/sites/default/files/pub/2014/PHI.pdf

48 ADB. 2011b. Country Partnership Strategy: Philippines, 2011-2016. Manila.

49 Footnote 48. 
several other $\mathrm{ADB}$ urban infrastructure and water development projects have contributed significantly to institutional strengthening of participating agencies and institutions, although not all of these initiatives have attained the desired outcomes. ${ }^{50}$ Lessons learned from ADB urban operations in the country that require incorporation into future project proposals are outlined below:

\section{Short-Term Political Cycles Hamper Long-Term Urban Development Vision}

The political cycle, with national elections every 6 years and local government elections every 3 years, overpowers development of a long-term vision for urban development due to shortterm priorities. Furthermore, personality-driven institutions and patronage-driven political factions contribute to conflicting priorities and unpredictable legislative outcomes that are likely to impact the pace and quality of reforms. Securing strong support from local mayors is essential and projects must encourage longer term commitments through investment strategies that have the support of future leaders.

\section{Maximize Development Effectiveness through Sector Loans}

A low level of budget provision for both loan proceeds and counterpart financing for projects, including water supply and sanitation, has hampered achieving the expected development impact. The Mindanao Basic Urban Services Project (MBUSSP) was designed by incorporating some of the lessons learned from the Philippine Regional Municipal Development Project, the Subic Bay Area Management Project. The MBUSSP, as a sector loan, incorporated more flexibility in the selection of participating LGUs than previous project loans. The MBUSSP not only financed the construction of basic urban infrastructure and services, including public markets, transport terminals, and water supply, but also less critical facilities such as gymnasiums and town halls. However, many were one-off interventions that had too little development impact, and the absence of multiyear investment planning has been detrimental and could diminish the effectiveness of investments in the urban sector.

\section{Water and Sanitation Sector Constraints}

A review of ADB's first urban generation projects led to the conclusion that LGU-operated utilities and community-based systems faced challenges in preparing, financing, and implementing expansive waterworks systems. In contrast, under the ADB Philippine Small Towns Water Supply Sector Project, the water district's service coverage expanded during the loan period, and improved monitoring and administration by the Water District allowed overall collections from water sales to increase, which later allowed the utilities to improve their debt positions and day-to-day operations. ${ }^{51}$

\footnotetext{
Footnote 40.

51 Footnote 40
} 


\section{Assessment of Subnational Lending and Ability of Local Government Units to Borrow}

The major lesson learned in financing was in the area of uncertain counterpart funding. Unavailable national counterpart funding threatened the implementation schedule under the Small Towns Water Supply Sector Project. ${ }^{52}$ With competing sources of funds available to LGUs, the demand for funds from institutions such as ADB is often unclear and unpredictable. As loans to local governments pass through the sovereign route, the cost of borrowing for LGUs is sometimes higher than for other available sources of funds. The demand for subprojects and loan funds has often been overestimated, with many local governments unwilling to borrow, especially for nonrevenue-generating projects. Many LGUs are unwilling to finance feasibility studies because costs are difficult to recover. Partners such as the Cities Development Initiative for Asia (CDIA) work closely with cities and are in a good position to undertake assessment of project demands, risks, and creditworthiness of LGUs using prefeasibility studies (PFSs). ADB can work more closely with CDIA to assess the willingness and ability of LGUs to borrow.

\section{Implementation Hindered by Interagency Issues}

The key lesson learned relating to institutional arrangements was that having multiple executing agencies complicates project implementation and monitoring. This was experienced, for example, during implementation of the Rural Water Supply and Sanitation Sector Project. The project required management skills from participating institutions, as cooperation was needed from a minimum of three government agencies at three levels, and communities in 20 provinces. Monitoring of project delivery and physical works was further constrained by decentralized implementation, a large number of locations, and the remoteness of certain subproject areas..$^{53}$

There are systemic obstacles to implementing projects in the Philippines, such as startup delays, ineffective flow of funds to LGUs through intermediaries, interagency disagreements, and insufficient implementing agency capacity. Previous ADB urban projects in Metro Manila included two sector development project loans: the Pasig River Environment Management and Rehabilitation Project, and the Metro Manila Air Quality Improvement Project. Under both projects, the policy components were satisfactory but the investment components suffered implementation delays because of shifting priorities, changes in scope, slow recruitment of consultants, disagreements on relending policies, and slow release or insufficient budget cover. Under the Pasig River project, the large-scale resettlement of 6,500 families proved difficult but ultimately successful. Urban redevelopment activities in prime locations, such as Makati City, were hindered by interagency disagreements, and demonstrate that scaling up urban redevelopment requires consensus on the use of prime land. Hence, interagency coordination and exchange of information is critical to achieving service efficiency.

\footnotetext{
52 Footnote 40.

53 Footnote 41.
} 


\section{Integrated Approach and Targeted Interventions for Urban Poor}

Improving access to urban services and shelter for the urban poor requires targeted interventions for inclusive growth. There are few loans available for the urban poor. The Development of Poor Urban Communities Sector Project set out to provide shelter financing and microcredit facilities for urban poor families. The overall take up of development loans by LGUs has been low, and the microcredit operation for home improvement has been slow because microfinance institutions have hesitated to participate. Working with the private sector proved more successful in the implementation of the socialized housing program, though it was not able to target the urban poor working and living in the informal sector, instead benefiting salaried employees who are members of the Home Development Mutual Fund (HDMF).

From 2003 to 2007, ADB supported the Strategic Private Sector Partnerships for Urban Poverty Reduction (STEP-UP) through a Japan Fund for Poverty Reduction grant of $\$ 3.6$ million. The goal was to reduce urban poverty in 23 post-Community Mortgage Program areas using an integrated development approach driven by strategic PPPs. The STEP-UP project promoted PPPs in providing housing, livelihood, and basic services to 9,126 urban poor households in eight selected cities in Metro Manila. Lessons indicate a strong capacity of organized communities and their homeowners, associations, jointly with LGUs and local neighborhood (barangay) offices, to supervise and implement their own settlement development and upgrading projects.

\section{Current ADB Focus (Sectors and Geography)}

In 2013, ADB responded to the government's call for emergency relief and reconstruction support when a major disaster hit central Philippines. ADB approved $\$ 500$ million for Emergency Assistance for Relief and Recovery from Typhoon Yolanda to support the government's additional public spending needs under its recovery program. ADB also approved \$372.1 million for the KALAHI-CIDSS National Community-Driven Development Project, which will help restore basic social services and rebuild affected communities using a community-driven development approach. ADB's Typhoon Yolanda response also includes an emergency grant of $\$ 3$ million under the Asia Pacific Disaster Response Fund, and a \$20 million grant from the Japan Fund for Poverty Reduction for emergency assistance and early investments, guarantees, B loans, and trade finance. ${ }^{54}$

ADB support in the area of environment, climate change, and disaster risk management will prioritize (i) strengthening ecosystem functions and the preservation of natural resources; (ii) enhancing climate change adaptation and disaster risk management, and in particular (a) undertaking cross-sector pilot activities on adaptation to build resilience to a changed climate; (b) supporting the government in gaining access to concessionary resources being made available for GHG mitigation in the energy, transport, and land use sectors at the global level (e.g., the Clean Technology Fund); and (c) working with the private sector and

54 ADB 2013. Philippines Fact Sheet. December 2013. Manila. 
the government on possible PPP solutions; and (iii) improving sustainable environmental infrastructure in urban areas.

In the area of urban environmental infrastructure, ADB will support policy and institutional reforms and investment needs to ensure sustainable financing of infrastructure and foster development of sustainable communities. The objective of $A D B$ assistance will be to strengthen water and sanitation, waste management, and flood control systems. ADB is committed to improving the condition of the road network, strengthening multimodal transport systems, and promoting sustainable urban transport, including support for nonmotorized transport and green technologies.

The Government of the Philippines, through the Bureau of Local Government Finance, requested $\mathrm{ADB}$ to provide capacity development TA to support local government revenue generation, land administration, and management reforms. The aim is to strengthen social and economic development, environmental management, and governance of local LGUs. The Support to Local Government Revenue Generation and Land Administration Reforms (REGALA project) is financed by the Japan Fund for Poverty Reduction and was included in the ADB 2010-2012 COBP for the Philippines.

The REGALA project commenced on 9 August 2011. Of the 10 LGUs awarded grants under the REGALA project, six are cities, two are municipalities, and one is a province. Most of the subprojects selected by the LGUs under the REGALA project have given priority to the adoption of a unified land information system based on a computerized revenue system (the enhanced tax revenue assessment and collection system or ETRACS) and a GIS. The more mature LGUs under components one and two will pursue deeper valuation reforms, and strengthening of land management and investment planning within the project time frame to August 2013.

The ADB Urban Sector Assessment, Strategy, and Roadmap further states that to support urban competitiveness, $A D B$ will focus on economic infrastructure, and to promote sustainable communities, emphasis will be on environmental infrastructure. The ADB South East Asia Urban Development and Water Division (SEUW) will promote an integrated approach for urban planning and environmental management for design of future environmental infrastructure investments as developed under the regional technical assistance, Green Cities: A Sustainable Urban Future for Southeast Asia.

The water and sanitation sector will focus on promoting sustainable communities through environmental infrastructure, as well as performance-oriented governance. This will be done mainly using a single-agency approach by seeking partnerships with the Department of Interior and Local Government (DILG), the Local Water Utilities Administration (LWUA), the Metropolitan Waterworks and Sewerage System (MWSS), and the Department of Health (DOH), and by developing long-term investment and institution-strengthening and capacity-building programs in the two subsectors. Whenever possible, water and sanitation programs and projects will be developed jointly, although substantial effort will be necessary in promoting sanitation programs, particularly during the initial years. 
SEUW is working with the Department of Environment and Natural Resources and the Municipal Development Fund Office on piloting integrated SWM in small to medium-sized municipalities that have shown commitment and willingness to invest in the sector. The project will be a sector loan supporting the implementation of the Solid Waste Management Act (RA9003) targeting sanitary landfills, waste to energy, and any other SWM investment needed to comply with the SWM law. Project preparatory TA (PPTA) for the Philippines Solid Waste Management Sector Project was approved in 2012 and technical assistance began in January 2013.

SEUW and the Regional and Sustainable Development Department (RSDD) supported the PRRC in a knowledge exchange platform by hosting a 1-day Pasig River Forum on 24 April 2012. The forum brought together key stakeholders to discuss issues for the sustainable rehabilitation and restoration of the Pasig River and the communities that live along the esteros (drainage canals). The outcome of the 1-day event was the signing of a declaration of support by all the key NGAs, mayors, LGUs, water utilities, nongovernment organizations (NGOs), and communities in committing to the target of achieving a water quality of class $\mathrm{C}$ for the Pasig River.

Based on the forum outcomes, SEUW prepared a small-scale TA project for the design of a pilot and demonstration activity to improve environmental conditions of the Estero de Paco and confluent esteros. With PRRC as the executing agency and a budget of $\$ 220,000$ in partnership with the Spanish Cooperation Fund, the duration of the TA project is from November 2012 to March 2013.

ADB has provided upstream support to cities in the Philippines in collaboration with the CDIA ${ }^{55}$ CDIA provides assistance to medium-sized Asian cities to bridge the gap between their development plans and the implementation of their infrastructure investments. CDIA uses a demand-driven approach to support the identification and development of urban investment projects within the framework of existing city development plans that emphasize environmental sustainability, pro-poor development, good governance, and climate change. To facilitate these initiatives at the city level, CDIA provides a range of international and domestic expertise to cities that can include support for the preparation of PFS for high-priority infrastructure investment projects as one of several elements. ${ }^{56}$

The CDIA activities in the Philippines include PFSs in four cities: Cagayan de Oro, Davao, General Santos, and Naga. More cities have asked for CDIA support and also several City Infrastructure Investment Programming and Prioritization tool kit applications have been made. CDIA supported Naga City to prepare a PFS for the Naga River Revitalization Project and to prepare business plans for various project components for phased river revitalization. Metro Naga and Naga City are interlinked by the Bicol and

CDIA is a regional initiative established in 2007 by the ADB and the Government of Germany, with additional core funding support from the governments of Austria, Spain, and Sweden as well as the Shanghai Municipal Government.

56 Cities Development Initiative for Asia. 2012. Pre-Feasibility Study Guidelines. Manila, Philippines. www.cdia.asia 
Naga rivers, both main drivers of the development in the area. However, pollution and poor infrastructure conditions along the Naga River affect the whole city and surrounding municipalities. Thus, the city now focuses on river revitalization including (i) improved drainage, wastewater treatment, and solid waste handling; (ii) flood protection and disaster risk reduction; (iii) informal settlement upgrading or near-site relocation; (iv) cultural heritage conservation and tourism development; and (v) water-based transport. CDIA further assisted the city in prioritizing between other infrastructure projects and interfaced with potential financiers. ${ }^{57}$

Consistent with the strategic theme of urban competitiveness, ADB support for economic infrastructure projects over the near term will include TA and possible lending for bus rapid transit projects. Davao, a competitive city, is likely to expand further. In response to the urban infrastructure need, the Transport and Communications Division (SETC), Southeast Asia Department; and the RSDD started working on an urban transport project in Davao, with the aim of improving public transport services and coverage area throughout a bus rapid transit system. A small PPTA project was provided under the regional TA: Preparing the Implementation of Asian City Transport. The expected loan amount is $\$ 20$ million.

Support for performance-oriented governance will be fully integrated into ADB operations involving all investments. Performance-oriented capacity development intends to cover economic development planning, investment programming, interagency coordination, infrastructure operation and maintenance, cost recovery and revenue generation, promotion of private sector investment, and local asset management.

An example of project implementation and monitoring support is the National Infrastructure Information System (NIIS), specially developed by $A D B$ as an online information and database system to support public sector agencies, from national ministries to local and provincial governments in DMCs, in the planning, preparing, documenting, monitoring, and financing of their priority infrastructure projects. Project teams including public agencies, engineers, environmental and safeguard specialists, development partners, financial advisors, and commercial partners such as developers, operators, and commercial banks can all work together in a secure online workspace to bring projects to fruition. The NIIS platform incorporates project structuring tools, project management tools, and a knowledge hub where users can exchange information, as well as international infrastructure project news feed. Using NIIS, project owners, lenders, and technical teams can capture project data in a systematic and consistent way across locations and multiple sectors. They can also identify and fill in any gaps in project planning and preparation, and guide a project, where appropriate, towards PPP structuring and institutional and commercial financing.

NIIS has been extended to support NGOs and/or civil society organizations in their work as implementing agencies for large donor-funded programs, with many small individual "microinfrastructure" projects at community level needing information management, coordination, consolidated donor reporting, etc. The outcome of the Project Preparation Program for Community Infrastructure Development is local government agencies being

57 CDIA. 2011. Project Overview. http://www.cdia.asia/wp-content/uploads/gravity_forms/41/2011/09/ PO-Philippines-Naga-new.pdf 
able to prepare and develop community-based or microinfrastructure projects, and increase collaboration and commitment from the private sector.

The regional technical assistance team is working with the Philippines Business for Social Progress to pilot a concept to (i) build the capacities of LGUs on small-scale infrastructure project preparation using the NIIS toolkit; (ii) identify innovative financing mechanisms for projects prepared on NIIS through engaging the private sector in corporate social responsibility activities and philanthropy; and (iii) establish a microinfrastructure network to engage private businesses, funders, NGOs, and local governments to create a foundation for soliciting and channeling in-kind and financial assistance from the private sector, thus complementing and sustaining efforts initiated by NGOs and government sector infrastructure-project specific activities. The network will also serve as a platform for knowledge sharing.

\section{Current Development Partner Focus}

The Urban Climate Change Resilience Trust Fund is an innovative trust fund set up through a partnership between ADB, the Department of International Development of the United Kingdom (DFID), and the Rockefeller Foundation, which aims to scale up the response to building urban climate change resilience in Asia. This trust fund has selected the Philippines as one of the countries for its initial focus based upon the country's vulnerability to climate change, the enabling environment in terms of decentralized planning, and strong city networking. The core strategy would be to strengthen city-level planning systems, processes, and multi-stakeholder engagement (including the urban poor) in "climate-smart" urban planning.

The World Bank has been involved in the sector much longer than ADB; from 1961 to 2007 , urban sector lending was $\$ 2.6$ billion, of which loans to Metro Manila amounted to $\$ 878$ million. The World Bank experience indicates that an appropriate level of cost-sharing incentives can encourage LGU investments in critical sectors, such as SWM, environmental protection, and revenue generation as well as support for informal communities affected by proposed subprojects. However, a corresponding TA project needs to be extended to enhance the capacity of the LGUs to operate and sustain the built infrastructure. Financial assistance to private sector proponents for subprojects that support local development has brought in private capital and management experience to enhance the delivery of services that have traditionally been undertaken by LGUs. Other multilateral agencies involved in the urban sector include the European Commission through the European Investment Bank, Cities Alliance, the United Nations Human Settlement Program (UN-HABITAT), and the United Nations Children's Fund (UNICEF). Bilateral contributions have come from Australia, Japan, United States.

ADB will support stronger social safety nets, including continued support for Pantawid Pamilyang Pilipino Program (4Ps), and strengthened and better-targeted social protection. ${ }^{58}$ It will also support expanded, better quality social services, including supporting the

58 This includes support for the government's reform agenda aimed at consolidation and/or phasing out fractured, ineffective programs, and channeling funding to a smaller number of more efficient and better-governed programs. 
government's new $\mathrm{K}$ to 12 agenda for education. Working with other development partners, ADB support in these areas will also (i) strengthen institutional mechanisms for the targeting and delivery of programs that directly or indirectly address poverty (e.g., conditional cash transfer, education, health, and rural and urban development programs) and capacity at the national and subnational levels; (ii) promote the government's agenda of convergence and rationalization across programs to cohesively tackle demand- and supply-side issues, and connect the poor to programs (such as rural infrastructure and employment promotion) to support their sustainable exit from poverty; and (iii) enhance the collection and analysis of poverty statistics, and their use in decision making. ${ }^{59}$

\section{Capacity Development Needs Assessment}

Ineffective urban planning and land management has been identified as a core problem on the institutional front. Effective development of urban areas and the delivery of urban services is reliant on effective urban management and governance, efficient institutions, and skilled human resources. The capacity needs assessment for the Philippines urban sector identifies a need for capacity development. The pool of skilled human resources for urban management needs in the Philippines is critically low, largely due to the limited educational opportunities in the area of urban planning and management.

\section{Human Resources: Institutions of Capacity Development}

There are two key national institutions for capacity development in the Philippines in the areas of urban planning and urban management. These are (i) the Asian Institute of Management (AIM) - Center for Development Management, and (ii) the University of the Philippines-School of Urban and Regional Planning (UP SURP). Besides these, the CDIA has played a key role in capacity building in the Philippines.

\section{Asian Institute of Management}

AIM, through its Center for Development Management (CDM), offers capacity development programs relevant to urban management. The courses-designed for policy makers, decision makers, and project managers-aim to equip participants with concepts on urban management, PFSs, project design and management, water access and sanitation, waste water management, and environmental management. These are under open enrolment or development executive programs. These are as follows (i) Introduction to Pre-Feasibility Studies (PFS): Translating Urban Development Strategies into bankable projects (in partnership with CDIA and UN-Habitat), and (ii) Urban Water and Sanitation Management Program.

59 ADB. 2011k. Thematic Assessment: Poverty. Country Partnership Strategy: Philippines, 2011-2016. Manila. The Poverty Analysis Summary is based largely on ADB. 2009c. Poverty in the Philippines: Causes, Constraints, and Opportunities. Manila. It also draws on sector and thematic assessments for the country partnership strategy. 
The Center for Development Management, in collaboration with the CDIA, offered a special program on urban development management in 2009-2010 for city managers and national partner organizations of CDIA. However, this course has not been offered as an open public course though it has great potential to build capacity for the LGUs. AIM also offers an urban management course as an elective subject under its Masters in Development Management. AIM conducts a capacity development course for the National Movement of Young Legislators to focus on strategic management for development, zeroing in on concepts and strategies that can be practically applied in their duties as legislators.

\section{Cities Development Initiative for Asia}

CDIA has played an important part in capacity development in urban management. The CDIA-DILG strategic partnership is the first formal national partner organization of CDIA in the Philippines since the signing of the memorandum of understanding (MOU) in 2011 has been put into concrete action. The technical working team, composed of representatives from both organizations, has prepared a work plan, and training to capacitate institutionalization of CDIA tools, especially the City Infrastructure Investment Programming and Prioritization tool kit and PFSs, are under way.

The MOU between ADB, CDIA, and UN-Habitat further strengthens the strategic support CDIA extends to cities in the Philippines, both in the form of TA and institutional capacity development, and in the form of linking cities and their infrastructure needs to finance (as the Philippines is one of four countries in which CDIA support is channeled through an $\mathrm{ADB}$ contract with UN-Habitat). With regards to linking to finance, CDIA has developed a "financier mapping toolkit" to identify potential financiers and investors for the respective projects.

CDIA has further strengthened its commitment to socially inclusive and pro-poor infrastructure investments and operational models by developing and distributing to all its consultants the "CDIA Checklist for Pro-Poor and Socially Inclusive Urban Infrastructure Development." This is a new and already highly successful, easily applicable tool for consultants and city administrations. Several training events have been carried out and are continuing to be held around Asia with participation of Philippine city officials on PPP in Bangkok and Shanghai, and on urban infrastructure financing in Kuala Lumpur, as well as other events.

\section{University of the Philippines - School of Urban and Regional Planning}

The Philippines has only one main school of planning, UP SURP. In 1965, the Philippine Republic Act 4341 established the Institute of Planning as a national policy institute aimed at

(i) strengthening the capability of national and local government agencies and private organizations to find solutions to their development problems,

(ii) improving human settlements and their environments through comprehensive integrated planning, and

(iii) developing and making available a pool of capable professional urban and regional planners. 
In 1981, the master of arts (MA) degree title changed to Master of Arts in Urban and Regional Planning. In 1982, the doctor of philosophy (PhD) in Urban and Regional Planning was launched. In 1992, the Diploma in Land Use Planning and the MA in Transport Planning were introduced in the curriculum. In 1995, UP SURP became the Asian partner of the University of Dortmund, Germany for master of science (MS) in Regional Development Planning. In 2008, UP SURP underwent curriculum changes and reintroduced fields of specializations, namely, estate planning, transport planning, public works planning, and environment and natural resource planning (Castro 2012) (Chart 21).

The university offers the Environmental Planner EnP Certification (P.D. 1308) developed under the Law Regulating the Environmental Planning Profession in the Philippines (P.D. 1308). The curriculum covers environmental planning activities concerned with management/development of land, and preservation/conservation/rehabilitation of the human environment. It enables certified professionals to offer services in the form of technical, consultation planning and preparation/implementation for (i) community/ town/city/regional development, site development for housing/education/industry/water resources, etc.; and (ii) land use and/or zoning plans and preinvestment and PFSs. However, there are issues and constraints in the successful implementation and use of this certification as there is under-enrolment in environmental planning (including urban and regional planning) courses offered by universities. This is largely due to a lack of understanding of the field of environmental planning resulting in a low number of environmental planning professionals, and the noncompliance to P.D. 1308 (environmental planning certification) in the development planning process.

Chart 21. Total Number of Graduates by Degree Program, 1999-2012

\begin{tabular}{|c|c|c|c|c|c|c|c|c|c|c|c|c|c|c|}
\hline Program & ํㅇ을 & 융 & 듀유 & ํํ & m̊ & ㅇํㅇ 융 & ப் & 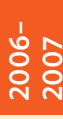 & 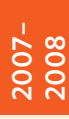 & 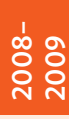 & ㅇํㅇ응 & 응 둥 & 듕 중 & $\begin{array}{l}\text { Average } \\
\text { Graduates } \\
\text { Per Year }\end{array}$ \\
\hline $\begin{array}{l}\text { Diploma in Transportation } \\
\text { Planning }\end{array}$ & - & 1 & 2 & 4 & 5 & 6 & - & - & - & - & - & - & - & 4 \\
\hline $\begin{array}{l}\text { Diploma in Urban and Regional } \\
\text { Planning }\end{array}$ & 49 & 73 & 53 & 35 & 42 & 59 & 45 & 46 & 28 & 18 & 25 & 29 & 19 & 40 \\
\hline $\begin{array}{l}\text { Master of Arts (Urban and } \\
\text { Regional Planning) }\end{array}$ & 17 & 8 & 19 & 17 & 16 & 16 & 16 & 7 & 17 & 7 & 2 & 10 & 8 & 12 \\
\hline $\begin{array}{l}\text { Master of Arts (Urban } \\
\text { and Regional Planning) - } \\
\text { Transportation Planning }\end{array}$ & 2 & 5 & 3 & - & - & - & - & 1 & - & - & - & - & - & 1 \\
\hline $\begin{array}{l}\text { Master of Arts (Transportation } \\
\text { Planning) }\end{array}$ & - & - & 1 & 1 & - & 4 & - & 1 & - & 1 & - & 1 & - & 1 \\
\hline $\begin{array}{l}\text { Master of Arts in Regional } \\
\text { Development Planning }\end{array}$ & 12 & 8 & 3 & 1 & - & - & - & - & - & - & 1 & - & - & 2 \\
\hline $\begin{array}{l}\text { Master of Science in Regional } \\
\text { Development Planning }\end{array}$ & - & - & 5 & 6 & 13 & 12 & 8 & 11 & 14 & 10 & 2 & 3 & 5 & 7 \\
\hline $\begin{array}{l}\text { Doctor of Philosophy (Urban and } \\
\text { Regional Planning) }\end{array}$ & 1 & 1 & - & 1 & - & 2 & 2 & 2 & 3 & 3 & 2 & 1 & - & 1 \\
\hline Total Graduates & 81 & 96 & 86 & 65 & 76 & 99 & 71 & 68 & 62 & 39 & 32 & 44 & 13 & 64 \\
\hline
\end{tabular}

- = data not available.

Source: Castro, J. 2012. Role of the UP School of Urban and Regional Planning in the Certification of Urban Planners in the Philippines: Prospects, Issues and Quezon City: UP SURP. 
The University of the Philippines through SURP, and the Ateneo de Manila University through the Ateneo School of Government forged an MOU to enhance cooperation in education and research activities. Specifically, the MOU aims to promote capacity development for environmental governance and environmental planning with the overall goal of effectively responding to climate change challenges and contributing to sustainable development. A central component of the MOU involves the joint development, promotion, and implementation of academic programs on climate change adaptation and mitigation.

UP SURP also extends support and technical assistance to government, NGOs, and the private sector on policy formulation and plan preparation for the development of localities and regions. It provides capability building-related courses on urban and regional planning through

(i) Special Course in Urban and Regional Planning;

(ii) Special Course on Urban Transport; and

(iii) Linkages with international and/or local organizations and universities for joint academic programs, faculty-student exchanges, joint research and/or training with the Technical University of Dortmund, Germany; Royal Melbourne Institute of Technology, Australia; SeoulTech, Republic of Korea; and the University of Newcastle, Australia.

\section{Urban Service Delivery (Management and Governance)}

The capacity needs assessment for the Philippines urban sector indicates a weak capacity for development planning, management, and enforcement. Lack of capacity of LGUs in project planning, packaging, and implementation should be addressed through capacity development training in project planning and urban management.

Key subsector issues relate to economic and environmental infrastructure such as water, sanitation, drainage, solid waste management, urban transport, growth of informal settlements, and the need for urban redevelopment. The performance of these subsectors and related investment needs is affected by remaining and unaddressed policy issues, comprising institutional coordination, management and technical capacity, as well as public and private financing needs and arrangements. For example, the core problem for SWM is poor disposal of collected and uncollected waste. LGUs generally have little capacity to plan, develop, operate, and maintain sanitary landfills and have difficulty in complying with the Ecological Solid Waste Management Act of 2000. Hence, there is an urgent need to improve the capacity of the LGUs to implement and enforce the policy and regulatory reforms.

\section{Public Institutional Assessment (Organizational)}

Urban development in the Philippines is guided by an extensive policy and legislative framework, but the corresponding institutional framework is fragmented. The institutional environment for the urban sector is highly complex. Urban development is not widely recognized as a major priority of the government. Capacity at the national and local levels in various aspects of urban development is largely inadequate. 
Limits to economic growth in the urban sector are seen as the key constraint and the core problem resulting in limited competitiveness of urban areas. This is attributable to years of underinvestment in urban infrastructure and services. Inadequate infrastructure to attract investment, lack of incentives to promote growth in regional centers, weak capacity for local development planning and implementation, uncoordinated government response, and unpreparedness of LGUs for natural disasters and climate change are the main contributors to limiting economic growth. Moreover, there is insufficient knowledge and tools at the local level to formulate and implement strategic and local economic development plans.

The Cities Alliance in partnership with the League of Cities of the Philippines, the World Bank, UN-Habitat, Japan International Cooperation Agency (JICA), and ADB has supported the Philippines' City Development Strategy program in three phases for more than a decade. Several ADB urban infrastructure projects have contributed significantly to institutional strengthening and capacity development of participating agencies, although not all have been rated successful.

Lessons learned indicate the strong capacity of organized communities and their homeowners' associations, jointly with LGUs and local neighborhood (barangay) offices, to supervise and implement their own settlement development and upgrading projects. Thus, investment projects and capacity building initiatives must be demand driven, and represent priorities defined by the LGUs and their respective communities.

Increasing ownership and commitment of LGUs to the project is an essential element to its successful implementation. Cost-sharing principles-proportions of grants, loans, and equity-should promote local ownership with commitment demonstrated through welldefined strategic development plans, and with clear investment priorities. Future ADB interventions will be limited to one subsector with several participating LGUs, or to a single LGU to increase the focus of investments. Projects will be managed by a single coordinating agency and carried out by a minimal number of implementing agencies. Single subsector and single-agency approaches, in combination with capacity-building support, will be used to promote sustainable development impacts.

By concentrating on addressing the investment needs and associated policy, institutional, and regulatory reforms in a single subsector, cumulative local development impacts can contribute to long-term and sustainable results at the national level.

Capacity development support for LGUs should be for

(i) economic development planning,

(ii) investment programming,

(iii) interagency coordination,

(iv) infrastructure operation and maintenance,

(v) cost recovery and revenue generation, and

(vi) promoting private sector investment. 


\section{Urban Finance Institutions (Private Sector Capacity)}

The government has limited fiscal capacity to meet urban development needs. Government financing institutions (GFIs), principally the LBP and the DBP, are the major source of medium-term loans for LGUs. GFls maintain a competitive advantage over the private sector due to their access to concessional official development assistance funds.

Creditworthy LGUs are authorized to fund revenue-generating projects through GFIs, private financing institutions, the bond market, or PPP arrangements. However, due to substantial dependence on IRA, the revenue-raising power of the LGUs is underutilized. This is also due to a lack of knowledge and capacity in bond flotation and PPP processes. The government has launched a program to attract private infrastructure investment by promoting PPPs. However, private financing institutions are hesitant to lend to LGUs because of their poor creditworthiness embedded in

(i) incomplete information and database of financial operations, assets, and revenues resulting in weak tax administration capacity;

(ii) weak resource mobilization capacities, poor cost recovery track records due to political intervention, and lack of collection procedures and systems; and

(iii) weak capacity in project planning, packaging, and implementation. ${ }^{60}$

60 Footnote 41. 


\section{Urban Needs Assessment}

\section{Sector-Based Needs Assessment}

Cities in the Philippines are contending with urban problems such as congestion, overcrowding, poor quality of life, and rapidly growing poor urban communities. The government needs to address the current situation, plan for, and finance substantial urban development needs. This is a particularly urgent concern in light of the fact that the urban population is expected to grow by as much as $67 \%$ by 2030 (adding an additional 34.8 million inhabitants to the country's urban areas). This rapid rate of urban growth is being driven by limited employment opportunities in rural areas, land shortages, natural disasters, and the negative impacts of climate change. ${ }^{61}$

\section{Housing}

Decentralization is still under process, as there remains a high degree of involvement of national agencies in essentially local concerns such as housing. The public sector housing in the Philippines is organized under the Office of the Vice President. The key shelter agencies involved are Housing and Urban Development Coordinating Council (HUDCC), Housing and Land Use Regulatory Board (HLURB), National Housing Authority (NHA)-supported in-shelter financing by the Social Housing Finance Corporation, and the Home Development Mutual Fund (HDMF), popularly known as the Pag-IBIG fund.

The Urban Development and Housing Act (UDHA) of 1992 or RA 7279 empowered the local government units (LGUs) to address urban development issues, paved the way for participatory governance, and ensured private sector participation in the national shelter program through a mandatory requirement to set aside $20 \%$ of all proposed subdivision areas for socialized housing. However, flexibility in meeting this requirement through provision of off-site housing, often far from the urban center, contradicts the purpose of providing affordable social housing for the urban poor near employment opportunities. The mandatory requirement can also be offset through payment for units to the NHA, the building arm of the government, responsible for construction of social housing. However, the provision of social and affordable housing within metropolitan areas remains inadequate.

Urban population growth outpaces service delivery. Affordable shelter and land markets have not kept pace with rapid urban growth: more than $40 \%$ of urban families have to live in makeshift dwellings in informal settlements. While official data indicate that only about $20 \%$ of the 7.5 million urban households fall below the poverty income line (P13,915 per capita per year as of 2001), the poverty income line alone does not capture the dire situation of informal

61 ADB and the Government of Australia. 2011. Competitive Cities in the 21st Century: Cluster-Based Local Economic Development Revealed: The Philippines. Manila: ADB. 
settlers. Many of the urban poor living in informal settlements suffer from lack of access to a safe water supply and sanitation, proper solid waste disposal, poor-quality housing, insecure tenure, and high risks to public health. Moreover, complicated legal processes prevent them from obtaining legal title (ADB 2008a).

Empowering communities will increase accountability and transparency in the monitoring and implementation of the upgrading strategies for poor urban communities in an otherwise inefficient land and housing market. The government needs to ensure the protection of rights and to promote compliance with regulations by all agencies responsible for delivery of housing, including the private sector. Access and delivery of urban services have made significant progress but are constrained by the weak institutional capacities of LGUs.

The Pabahay Caravan is an outreach model that takes national government agencies (NGAs) to the doorstep of local bodies. The Pabahay Caravan is the government's token response to strengthen local government unit (LGU) capacities through national-local and inter-local coordination, one of the key objectives of the NUDHF to ensure consistency in planning and implementation. The emphasis is on meeting the needs of the poor through socialized housing schemes under the Community Mortgage Fund, Abot Kaya Pabahay Fund, and the localized Community Mortgage Program by the Social Housing Finance Corporation, and the needs of lower- and middle-income groups through affordable housing schemes of the Pag-IBIG fund. The Pag-IBIG fund has successfully responded to the need for a national savings program and an affordable shelter financing option for Filipino workers. With a demand of more than 3.7 million units nationwide and more than 80,000 in the National Capital region (NCR), HUDCC and its key agencies are trying to meet the housing challenge through a coordinated effort. Economic strategies and employment creation need to be spatially integrated with the housing needs to meet the diverse challenges.

\section{Water Resources}

The Philippines has total annual renewable water resources of 479 billion cubic meters $\left(\mathrm{m}^{3}\right)$ from its surface water and groundwater sources amounting to an annual per capita availability of about $6,100 \mathrm{~m}^{3}$, which is twice that of the rest of Asia, and six times the global scarcity threshold of 1,000 $\mathrm{m}^{3} .62$ The National Water Resources Board (NWRB) estimates the total available groundwater supply to be 20,200 million $\mathrm{m}^{3} / \mathrm{year}$. Based on an $80 \%$ probability for

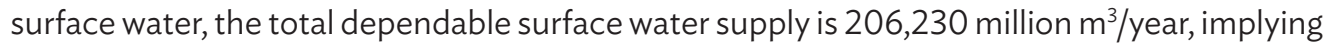
a total mean supply of 226,430 million $\mathrm{m}^{3} /$ year. Agricultural use accounts for $83 \%-85 \%$ of this amount, the remainder being shared by the industry, commercial, and domestic sectors. A growing population, especially in the urban areas, together with water pollution, wasteful and inefficient use, continued denudation of forest cover (particularly in watersheds), and saltwater intrusion caused by excessive withdrawal of groundwater (particularly in the metropolitan areas of Cebu, Davao City, and certain areas of Metro Manila) are the major challenges facing the country's water resources. ${ }^{63}$

62 Based on data from the database of the World Resources Institute and Government of the Philippines. 2007. Philippine Water Supply Sector Roadmap. Manila. Quoted in ADB. 2012a. Philippines: Water Supply and Sanitation Sector Assessment, Strategy, and Road Map. Manila.

63 Footnote 41. 


\section{Water Supply}

Local water resources are dwindling in the face of massive increase in demand. Many urban areas face poor quality water, interrupted supply, and limited access. In March 2012, the World Health Organization (WHO)-UNICEF Joint Monitoring Programme (JMP) reported that the Millennium Development Goal (MDG) of 92\% coverage has been met for drinking water. ${ }^{64}$ The JMP estimated that national coverage in the Philippines was 92\% in 2010, with $93 \%$ in urban areas and $92 \%$ in rural areas. The National Statistics Office (NSO) reported a lower figure of $84.8 \%$ of the national population having access to potable water (Levels I and II) in 2011, noting a slight increase from $84.1 \%$ in 2009.65

According to the March 2012 JMP report, 43\% of the country's population had access to water piped into private premises (Level III) in 2010. However, the report highlighted a wide disparity in access between urban and rural areas: $61 \%$ in urban areas compared to only $25 \%$ in rural areas. Many water supply systems are inefficient because of obsolescence, poor maintenance, and water theft. Contaminated drinking water and waterborne diseases remain a major public health concern. ${ }^{66}$

The Philippine Water Supply Sector Roadmap, prepared in 2008 by the government, focuses development interventions on the following major sector outcomes: (i) institutional strengthening, (ii) capacity development, (iii) strategic alliance building, and (iv) adequate infrastructure provision, which will lead to improved water supply infrastructure and service provision.

There are no validated numbers for Level III water service providers (WSPs), and there is no harmonized national database for water supply coverage. In several sector reports, the number of Level III water systems in the country is estimated to range from 3,000 to 6,000, reflecting the broad array of WSPs including many small-scale water service providers in smaller cities and municipalities, especially in rural areas. There are numerous communitybased water service providers such as cooperatives, rural water supply associations, barangay water service associations, homeowners' associations, and property developers that supply water. The vast majority of these are not registered with NWRB, nor are they attached to a national agency. There are also no comprehensive sector statistics on water distribution service levels or quality among WSPs (i.e., continuity of water supply [e.g., 24 hours per day, 7 days per week], quality of water supplied, or supply of water on a per capita basis).

64 The WHO-UNICEF Joint Monitoring Programme (JMP) for water supply and sanitation is the official United Nations mechanism tasked with monitoring progress toward achieving MDG-7, or halving the proportion of the population without access to water and basic sanitation. http://www.wssinfo.org/ (accessed July 2012).

65 National Statistical Coordination Board. 2011. Summary of StatDev 2011 Indicators by Sector and by Pace of Performance. http://www.nscb.gov.ph/stats/statdev/2011/Accelerating_infra/Chapter_accelerating _infra.asp (accessed July 2012).

In the Philippines, water systems are classified into one of three levels: Level I, stand-alone water points (hand pumps, shallow wells, rainwater collectors); Level II, piped water with a communal water point (e.g., bore wells, spring systems); and Level III, piped water supply with a private water point (household service connection).

66 For further information of subsector issues refer to the problem tree analyses in ADB. 2012a. Philippines: Water Supply and Sanitation Sector Assessment, Strategy, and Road Map. Manila. 
Water supply and sanitation in Metro Manila and adjacent provinces are provided by the MWSS and its two private concessionaires, Manila Water Company, which is the concessionaire serving Manila's east zone, and Maynilad Water Services, the concessionaire serving Manila's west zone.

Outside Metro Manila, LGUs are responsible for providing frontline basic services, including water supply. The Provincial Water Utilities Act of 1973 (Presidential Decree 198) created the water district concept. LGUs were thus encouraged to transfer their water supply systems to water districts, which are corporatized stand-alone entities supplying water in a franchise area. As a government-owned specialized lender to Water Districts, the Local Water Utilities Administration (LWUA) was also established, its dual role being that of tariff regulator and institutional development advisor. At present, the major utilities operating Level III systems in urban areas are (i) Water Districts, which are local corporate entities formed at the option of the LGU, (ii) LGU-owned and operated water utilities, and (iii) a few private sector operators that have been given a franchise or authority to operate within the geographical jurisdiction of an LGU or an industrial zone. According to LWUA, as of the end of 2011, 861 WDs had been established, of which 502 were operational, their number of service connections ranging from 500 to 200,000 (with an average of 7,011 connections each). ${ }^{67}$

It is estimated that about 1,000 LGU-run water utilities operate in urban and rural areas throughout the country. According to the project management unit of the Department of Interior and Local Government (DILG), there are about 350 LGU-operated Level III systems, with an average of about 900 connections each. These utilities are part of the LGU concerned, with budgetary allotments coming directly from the LGUs. These systems are basically self-regulated by the LGU executive and legislative units. LGU-run water utilities face strong political pressure to keep water tariffs low, often below cost-recovery levels, and the absence of commercial practices such as ring-fencing likely masks the indirect material subsidies they receive for water supply.

Collectively, the two Metro Manila concessionaires, the 502 operational water districts, and the 350 LGU-run water utilities together comprise around 850 water utilities that provide Level III water supply, primarily in urban areas. Collectively, they service about 1,009 LGUs, or $60 \%$ of all cities and municipalities in the Philippines.

\section{Sanitation}

Few households are connected to a sewerage network (less than 3\% to 5\% by most estimates) (Chart 22). The absence of communal sewer systems in urban areas has meant that stormwater drains are frequently also used for wastewater disposal. The majority of households with toilets are connected to septic tanks that are poorly designed or maintained, most effluent thus likely to be discharged without treatment.

67 Footnote 40 


\section{Chart 22. Use of Sanitation Facilities, 1990-2008 \\ (\% of population)}

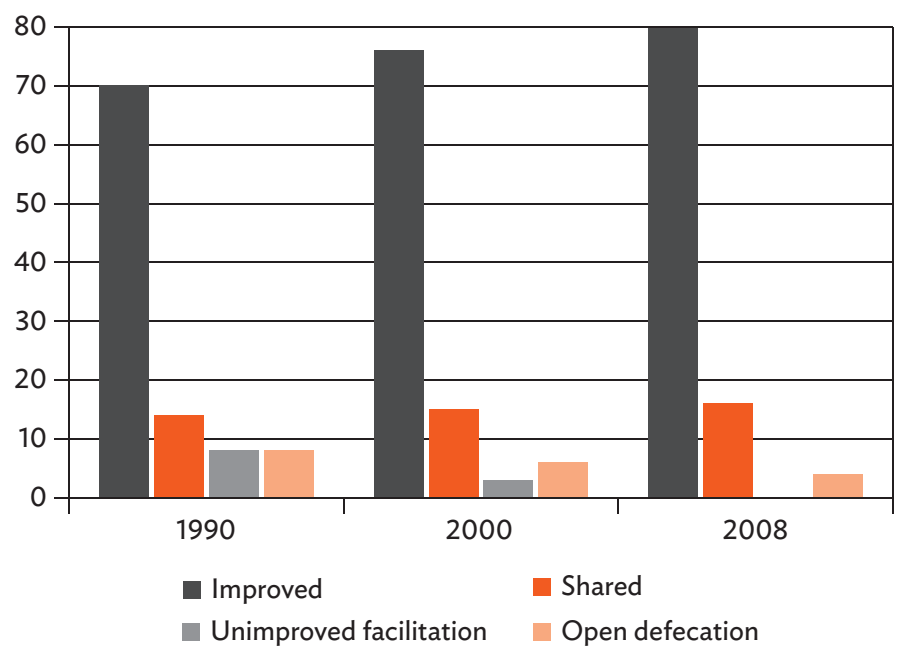

Source: National Statistics Office (NSO). 2010. Philippine Statistical Yearbook. Manila.

The bulk of expenditure in the sector is undertaken through (i) the the Department of Public Works and Highways, (ii) two government-owned and controlled corporations (i.e., the MWSS and the LWUA, both of which are agencies attached to the DPWH), and (iii) the two private concessionaires in Metro Manila-Manila Water Company, Inc. and Maynilad Water Services, Inc. From 2007, the national government increased investments in the sector outside of Metro Manila, though its overall level of spending remained low. Most DPWH water projects are flood-control related, its other projects relate to roads, highways, and bridges. Significantly, after 2007, water and sanitation investments funded by national government agencies declined dramatically in Metro Manila, as the two private concessionaires rolled out a major sanitation program that is primarily privately financed. In 2008, the Supreme Court order to Philippine government agencies "to clean up, rehabilitate, and preserve Manila Bay, and restore and maintain its waters to SB level to make them fit for swimming, skin-diving, and other forms of contact recreation" triggered an extensive investment program and the extension of the concession term. ${ }^{68}$

In 2009, the Philippine Sustainable Sanitation Roadmap was prepared by the government, which will be the basis for the formulation of sustainable sanitation programs for at least three Philippine Development Plans (PDPs) (2011-2028). This road map forecasts that the 2015 MDG sanitation target can be achieved. The road map envisions that by 2028, universal access (100\%) to safe and adequate sanitary facilities will have been provided, that behavior change and proper hygiene practices are accepted norms within families and communities, and that mechanisms for sustainable sanitation (i.e., linkages with health, agriculture, and the environment) are institutionalized. Achievement of the sanitation

68 Republic of the Philippines. 2008. Supreme Court Decision. G.R. Nos. 171947-48. 18 December. http://www.pemsea.org/sites/default/files/manilabay-supremecourt-decision.pdf 
sector vision is linked, similarly to water supply, to responsive sanitation governance, and a regulatory framework. ${ }^{69}$

As reported by the JMP in March 2012, the Philippines recorded a 17\% improvement in sanitation coverage in 2010 as compared to 1990 levels. NSO reported that the proportion of the population with access to basic sanitation, i.e., sanitary toilets, was $92.5 \%$ in 2011 but projected to decrease to $83.6 \%$ in 2016 given the urbanization trends. ${ }^{70}$

Weak management of solid waste and sanitation is a big challenge, and contributes to contamination and pollution of surface and groundwater sources. Thus the main constraints on development of the urban water and sanitation sector are (i) institutional fragmentation, weak sector planning and monitoring; (ii) lack of policies and effective governance and regulation for sanitation; (iii) low public and private sector investment; and (iv) weak performance of utilities. The constraints are more severe in the rural water supply and sanitation sectors due to unclear delineation of responsibilities and very limited access to financing, which has resulted from a decline in available government funds.

Key Investment Needs in Water Supply and Sanitation

- Extend service coverage of water utilities to get more people connected.

- Achieve full cost recovery tariffs.

- Develop a watershed plan with a combination of restoration and protection measures, as a superset of the land use plan.

- Support infrastructure-led development.

- Improve access by urban population to piped water on premises.

- Introduce an integrated tariff for water and sanitation.

- Make utilities more efficient and creditworthy.

- Undertake institutional strengthening, capacity development, planning, and monitoring.

\section{Solid Waste Management}

There are 40 sanitary landfills noted to be in compliance with the Ecological Solid Waste Management Act of 2000 (RA 9003) with 800 open and controlled dumpsites nationwide. ${ }^{71}$ Weak compliance of LGUs in completing their solid waste management (SWM) plans and limited financial capacity inhibit progress on reduction, reuse, and recycling of municipal solid wastes. It also hampers treatment of hazardous components and residual waste management through sanitary landfills, and the use of alternative technologies to process and/or treat the waste. Only $20.9 \%$ of the cities and municipalities in the country (338 LGUs) have completed their SWM plans. The share of LGUs served by sanitary landfills was $2.7 \%$ in 2010. Improved access by the urban population to adequate solid waste disposal is essential.

\footnotetext{
Republic of the Philippines. 2007. Philippine Sustainable Sanitation Roadmap. Manila.

70 Footnote 41.

71 National Solid Waste Management Commission. 2012. Manila. http://www.emb.gov.ph/portal/nswmc/ NSWMC.aspx
} 
Key Investment Needs in Solid Waste Management

- Capacity development on national and local levels to implement RA 9003

- Technology options for waste disposal

- Increasing efficiency in waste collection and management

- Scientific closure of dump sites and development of sanitary landfills

- Building of regional landfills through clustering of LGUs

- Exploiting cross-sector synergies such as waste-to-energy options

- Improving access by the urban population to adequate solid waste disposal

- Enabling a financing framework for a national-local government cost-sharing policy

\section{Flood Management}

The cumulative impact of floods on the loss of lives and damage to properties and livelihoods results in a deceleration of social progress and economic activity in affected areas. According to National Disaster Risk Reduction and Management Council, the number of lives lost as a percentage of the total population affected by flooding incidents has been steadily increasing from $0.003 \%$ in 2010 to $0.021 \%$ in 2011 . Existing flood control structures in identified high-risk areas have proved inadequate in handling the unexpected increase in stormwater discharge in highly urbanized areas. In the PDP, the construction of flood management structures in highly vulnerable areas is prioritized. This includes the following:

(i) The development of hazard maps.

(ii) The application of climate change adaptation and disaster risk management strategies in the planning and design of structures.

(iii) The development of mechanisms to expedite financing.

(iv) Increased LGU and community participation.

Reducing water pollution to improve water quality in priority rivers and other economically and ecologically important water bodies is one of the objectives identified in the PDP. Priority areas for clean-up have been identified, including Laguna de Bay and the Pasig River, using funds collected from identified polluters.

An updated Metro Manila flood control master plan has been long in the making. In September 2010, a synthesis report entitled, "Climate Risks and Adaptation in Asian Coastal Megacities" was issued by the World Bank, with findings from studies jointly conducted by the World Bank, Asian Development Bank, and Japan International Cooperation Agency. The report highlighted the fact that an existing JICA-supported flood control master plan since 1990 continued to serve as the basis for flood control infrastructure projects. As such, the initiatives focused mainly on mitigating flooding from Laguna de Bay, and channeling flood waters from Metro Manila into Manila Bay.

The new flood management master plan for Metro Manila was approved in July 2012 by the National Economic and Development Authority (NEDA) subcommittee on water resources. In September 2012, it was approved by the NEDA board, along with P5 billion in funding for 
Metro Manila and surrounding areas. This money is for financing immediate high-impact flood control interventions such as continuation of construction and rehabilitation of dikes, strengthening of seawalls, dredging of rivers, and construction of river control works. The plan calls for at least P351.7 billion ( $\$ 8.4$ billion) in infrastructure spending under 11 infrastructure projects, including construction of a large dam in Marikina, and improvements to the Pasig and Marikina river embankments. The projects will likely require the resettlement of thousands of people, many of whom are illegal settlers living along the rivers (Pasig-Marikina, San Juan, Upper Marikina-Wawa, Malabon-Tullahan, Meycauayan, and South Parañaque-Las Piñas), in Laguna lakeshore towns, and in the Manggahan Floodway with almost 1 million people in Metro Manila alone. The plan was funded by a $\$ 1.5$ million technical grant extended by the World Bank-administered Global Facility for Disaster Reduction and Recovery trust fund to the Government of the Philippines. ${ }^{72}$

Key Investment Needs in Disaster Risk Management and Flood Management:

- Comprehensive understanding of the whole river basin and urban water system

- Addressing the resettlement of informal settlements along waterways

- Coordinating road management and sanitation improvements for efficient stormwater discharge and street drainage

- Capacity building for improving resilience in urban planning and housing

- Improving resilience of infrastructure - updating standards for design and construction

- Preparing hazard maps to identify no-build zones

- Early warning systems and preparation of disaster response mechanisms including community preparedness and LGU training

\section{Energy}

Energy consumption has increased consistently with economic expansion (Charts 23 and 24). However, sustained economic growth is impeded by unreliability and high costs of power. Based on a study, the 10 locations with the highest electricity rates are Hawaii, Italy, Malta, Japan (Kansai), Cyprus, Germany, Denmark, The Netherlands, the Philippines (Meralco) and Singapore. ${ }^{73}$ The Philippines has the most expensive electricity in Southeast Asia, averaging $\$ 0.24$ per kilowatt-hour in 2012. This is because (i) the archipelagic geography makes electricity costly as transmission costs are $40 \%$ higher than the average of the other markets surveyed; (ii) generation, transmission, and distribution systems are inefficient; (iii) investment in the sector is low, coupled with the high cost of investments made during the country's power crisis in the 1990s; and (iv) lack of competition in the power sector. ${ }^{74}$

Asian distributors that fared better than Meralco either had their own domestic fossil fuel supply, nuclear power plants, or government subsidies. The country's peers in Southeast

\footnotetext{
Footnote 41.

73 International Energy Consultants. 2012. Regional Comparison of Retail Electricity Tariffs. Meralco. Manila.

74 ADB. 2011l. Thematic Assessment (Summary): Energy. Country Partnership Strategy: Philippines, 20112016. Manila.
} 

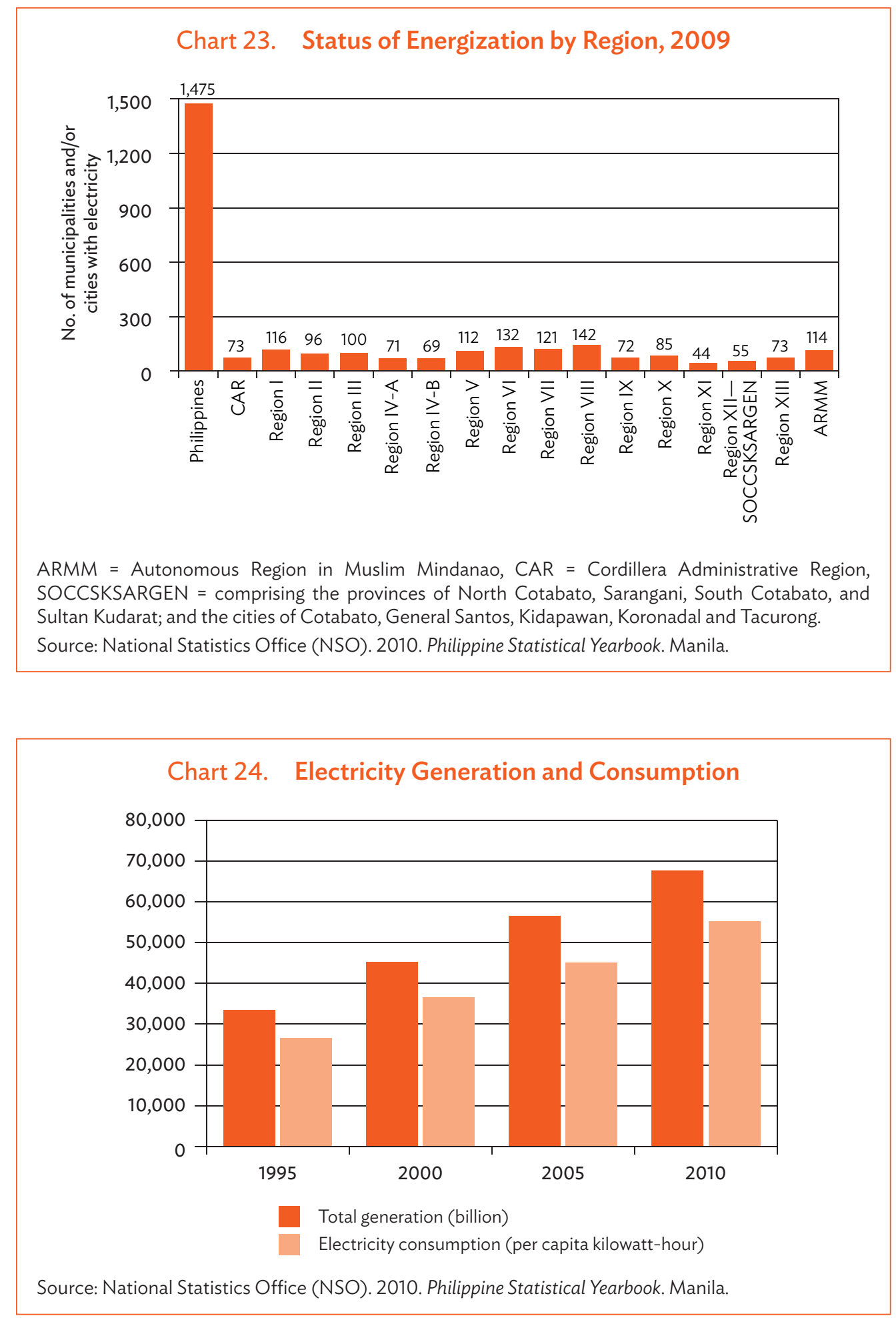


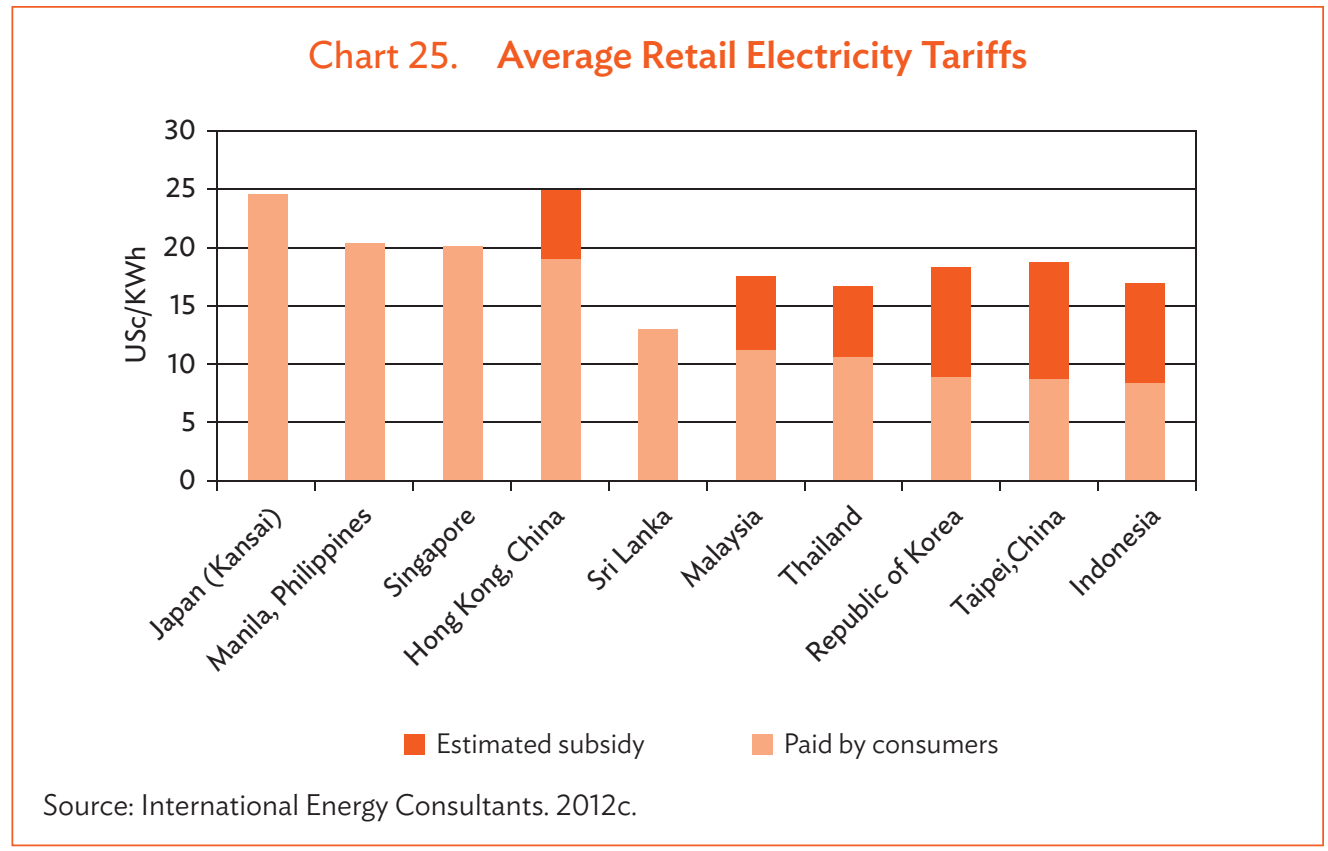

Asia had significantly lower electricity rates, with Malaysia ranking 37th; Thailand, 38th; and Indonesia, 43rd (Chart 25). State subsidies in the three Association of Southeast Asian Nations (ASEAN) countries cover between $36 \%$ and $54 \%$ of the cost of supplying electricity. Without these subsidies, the three countries would rank 14th (Malaysia), 19th (Thailand) and 17th (Indonesia), while the Philippines would still rank 9th. ${ }^{75}$

Reliable and secure electricity services at competitive rates are essential to improving the investment climate in a country that has limited fossil fuel reserves. The Philippines is one of the few countries in the world where renewable energy accounts for the largest share (35\% renewable energy; $2 \%$ hydro) of total primary energy supply. ${ }^{76}$ Energy demand is met partly by indigenous resources, including coal, natural gas, hydropower, and traditional biomass energy. With limited fossil fuel resources and an abundance of renewable energy sources, including solar, wind, biomass, ocean, small hydro, and geothermal, the Philippines is the world's second largest producer of geothermal power and the first country in Southeast Asia to deploy large-scale wind and solar technologies. ${ }^{77}$

In recent years, the Government of the Philippines opted to phase out petroleum as a primary fuel for power generation by increasing use of natural gas, with petroleum fuels used primarily for the transport sector. The commitment of the Government of the Philippines to promote power sector reforms and development of renewable energy is evident with the establishment of the National Renewable Energy Board in February 2009 to attain the

75 Interaksyon. 2012. PH electricity rates among 10 highest in survey of 44 countries. http://www.interaksyon .com/business/40664/ph-electricity-rates-among-10-highest-in-survey-of-44-countries

76 Footnote 46.

77 P. Maniego and L. Weischer. 2011. The Right Mix: The Philippines Achieving its Renewable Energy Goals. http://insights.wri.org/news/2011/07/right-mix-philippines-achieving-its-renewable-energy-goals 
objectives of the Renewable Energy Act of 2008 (Renewable Energy Act). In May 2009, the Department of Energy released the implementing rules and regulations of the Renewable Energy Act and created the Renewable Energy Management Bureau. The challenge in the energy sector is to ensure sustainable and reliable supply at a reasonable cost.

Key Investment Needs in the Energy Sector

- Renewable energy; energy efficiency and conservation

- Energy efficiency in urban services

- Energy-efficient buildings; energy-efficient technology

\section{Urban Transport}

Inadequate transport planning and ineffective traffic management is evident in most Philippine towns and cities. Traffic management systems such as $\mathrm{U}$-turns have been introduced for almost all major thoroughfares with frequent changes in the location of the turnings leading to traffic buildup and blocked roads. Traffic control devices, such as traffic signs, signals, and road markings often do not conform to official standards or meet needs.

Poorly integrated road networks are inadequate as a result of underinvestment and lack of attention to proper road maintenance. Road traffic accidents are increasing and are one of the leading causes of death, with children the most at risk. In large urban areas, air pollution has become a serious concern. Nationwide, urban public transport is dominated by jeepneys, filcabs, and tricycles, providing door-to-door service. Unfortunately, they contribute to severe traffic congestion, particularly around transit terminals and public markets, due to ineffective franchising and enforcement practices. Buses are common in Manila but not in smaller urban centers. Urban light rail transit is confined to Metro Manila and is heavily subsidized.

The lack of integrated urban transport planning leads to a higher average cost of transport, as there is a minimum fare for each of the different travel segments or "rides." New public transport terminals that integrate different modes of public transport are in great demand and could help reduce the high logistical costs, and thereby improve the economic productivity and competitiveness of urban areas.

Key Investment Needs in the Transport Sector

- Environmental concerns in the transport sector

- Integrated land use and transport; multimodal transport facilities

- Urban public transport; affordable transport options

- Sustainable transport, nonmotorized (NMT) options for flood adaptation

- Sector-wide management and reforms (governance and policy) 


\section{Urban Strategy and Prioritization}

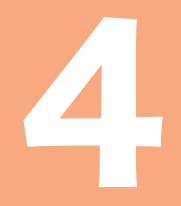

\section{National Strategy}

The Philippine Development Plan (PDP) 2011-2016 translates the "Social Contract with the Filipino People" into strategies and programs. Three broad strategies are to be employed to achieve inclusive growth: (i) attaining high, sustained economic growth through a stable macroeconomic environment, rapid growth of industry, investments in infrastructure, and curbing corruption and enforcing the rule of law; (ii) providing equal access to development opportunities by investing in human capital, especially in education, health, and other basic social services, and by leveling the playing field through improving access to infrastructure, credit, land, technology, and other productive inputs; and (iii) formulating effective social safety nets to ensure both the protection and the promotion of extremely vulnerable groups. Managing climate change adaptation and disaster risks and food security are key PDP priorities. The PDP is results-based, and national targets have been identified.

\section{Urban Sector Strategy}

The updated National Urban Development and Housing Framework (NUDHF) 2009-2016 describes the vision for urban development as a system that facilitates economic growth, develops and strengthens local competitive advantage, and significantly improves the quality of life of its residents. It sets a clear agenda for action through the following five goals:

(i) Urban competitiveness. Increase productivity and efficiency of urban industrial regions, build on existing strengths of manufacturing and producer services, and focus on export-oriented activities in globally competitive, core export areas (e.g., CALABARZON, Cebu, and Davao City).

(ii) Poverty reduction. Enhance rural-urban linkages to improve labor mobility and connectivity among rural producers and urban consumers; manage population growth and livelihood, entrepreneurial, and human resource programs aimed at poverty alleviation.

(iii) Affordable housing. Link development plans with local economic investment programs, unlock land for affordable housing, increase funding of proven programs and institutions, and streamline housing development transaction processes.

(iv) Sustainable communities. Use market-based incentives and disincentives to ensure that public amenities support urban land-use objectives, encourage sustainable planning and green building, and integrate climate change adaptation and disaster risk management into community and regional development.

(v) Performance-oriented governance. Provide incentives for LGUs to become less dependent on the internal revenue allotment (IRA); strengthen capacity in strategic planning, investment programming, budgeting, and implementation; improve 
vertical coordination; increase transparency and accountability; support publicprivate partnerships; encourage performance-based local governance; and support metro (interlocal) jurisdictional cooperation.

\section{ADB-Philippines Country Partnership Strategy}

In 2011, ADB and the Government of the Philippines agreed on a new country partnership strategy (CPS) 2011-2016 for the Philippines aimed at high, inclusive, and sustainable growth. The strategic thrust of the CPS is consistent with the PDP, 2011-2016 and includes (i) an improved investment climate and private sector development; (ii) more efficient, effective, and equitable social services delivery; (iii) reduced environmental degradation and vulnerability to climate change and disasters; and (iv) strengthened governance and reduced corruption.

ADB's partnership with the Philippines is based on the intersection of PDP priorities with ADB Strategy 2020 and its Urban Operational Plan (UOP), and is defined to be relevant and responsive to the needs of a lower-middle-income country. The key objective of ADB support is to help the Philippines achieve high, inclusive, and sustainable growth. Of the five core operational areas of Strategy 2020, the proposed lending program will focus on infrastructure, environment, and education. Regional advisory technical assistance (TA) will support regional cooperation and integration. ADB will continue the approach of combining policy-based lending with capacity development to support broader governance reforms while gradually expanding sector-level policy and investment lending. The objective is to enhance the direct contribution of the ADB-Philippines partnership in the PDP results areas while also addressing selective longer-term governance reforms.

$A D B$ is increasingly testing innovative and knowledge-based solutions, drawing on its position to identify and influence trends in Asia and the Pacific, its capacity for interdisciplinary and integrated approaches, its ability to blend knowledge with development finance, and its capacity to facilitate knowledge exchange and cooperation among developing countries in the region. ADB will remain responsive to the needs of the country in the case of exogenous shocks, such as disasters, and the effects of global or regional economic crises. During the CPS implementation, ADB will strengthen partnerships through (i) intensified engagement in the Philippine Development Forum and its working groups; (ii) stakeholder consultations; and (iii) establishment of an advisory board of eminent people, including academics and representatives of civil society organizations, to advise on the ADB country program and operations, and on ways to strengthen development effectiveness in the context of national developments.

The ADB Urban Sector Assessment, Strategy, and Roadmap 2010 states that to support urban competitiveness, $A D B$ will focus on economic infrastructure, and to promote sustainable communities, emphasis will be on environmental infrastructure. Performanceoriented governance and results-based lending will be a crosscutting theme in all ADB operations in the sector, and will thus be integrated into loan projects, as well as being a central element in stand-alone TA initiatives. 


\section{Urban Priorities}

T

he strategic investment priorities are a combination of the urban strategic vision set forth by the Philippines and ADB based on the overall sector-based needs assessment as set out in Chapter 3, and the urban vision outlined in Chapter 4. The key thematic priorities that emerged are given below.

\section{Building Urban Competitiveness}

(i) Provision of incentives to promote growth in regional centers and address regional disparities, urban imbalance, and migration.

(ii) Peri-urbanization of smaller towns and cities near major growth centers to stimulate economic growth and further capture benefits of urbanization.

(iii) Support strengthening of metropolitan governance.

(iv) Diversify export-oriented manufacturing and develop robust industry sector and provide infrastructure support.

(v) Enhance credit finance to support small and medium-sized enterprise (SME) development and support social infrastructure.

(vi) Investment in transport and tourism infrastructure to improve access and economic prospects of geographically dispersed regions.

\section{Planning for Inclusive Growth}

(i) Need to develop a robust industry sector to create more productive job opportunities for unskilled labor. Link education, vocational training, and skills development to employment creation with provision of supporting infrastructure facilities. Spatially distribute economic activity to address regional imbalance and income disparities.

(ii) Strategic investments in cross-sector initiatives such as health tourism and cultural tourism should be supported alongside alternative livelihood opportunities for natural-resource-dependent communities.

(iii) Address urban renewal through targeted investments for rehabilitation of lowincome communities in environmentally precarious urban areas.

(iv) Empower communities to increase accountability and transparency in monitoring and implementation of upgrading strategies for poor urban communities.

(v) Ensure protection of rights and promote compliance of regulations by all agencies, including private sector, responsible for delivery of housing in an otherwise inefficient land and housing market. Provide capacity development support. 


\section{Toward Resilient Cities}

(i) From acts to action: operationalize the environmental acts. Target investment in urban environmental infrastructure for climate change adaptation and mitigation.

(ii) Introduce greenhouse gas (GHG) emission reduction priorities in power and transport sectors. New transport technologies like e-jeepneys can mitigate transport emissions.

(iii) Review land use and land conversion policies. Establish transparent and accountable systems that enable organizational reform to bring in good governance in the real estate market.

(iv) Consolidate data on urban land use. Develop a centralized land-use database system with GIS mapping to aid government in tapping land value and increase efficiency in property tax collection.

(v) Provide reliable and secure electricity services at competitive rates that are essential to improving the investment climate and distribution management.

(vi) Enhance energy efficiency and technological support for renewable energy, consider waste to energy options, and others.

\section{Urban Governance-Recommendations for Improving \\ Urban Governance and Management}

(i) Establish governance mechanisms for coordination of planning and implementation of projects.

(ii) Form a unitary national agency with a strong mandate for urban development.

(iii) Develop capacity of local government units (LGUs) for technical and management skills.

(iv) Implement effective transparency and accountability mechanisms at national and local levels.

(v) Improve the domestic investment climate and legislation to encourage the domestic banking sector and the private sector to invest in infrastructure to attain long-term development goals. Develop a public-private partnership (PPP) center for capacity development of LGUs.

(vi) Strengthen tax revenues to ensure adequate resources for social and physical infrastructure development for sustainable economic growth.

Targeted investments require geographical focus to identify urban strategic areas or locations for ADB interventions. These are based on the government policy documents, other donor agency reports, and ADB sources. The spatial strategy and priorities set by NUDHF 20092016 are shown below (Map 4). 


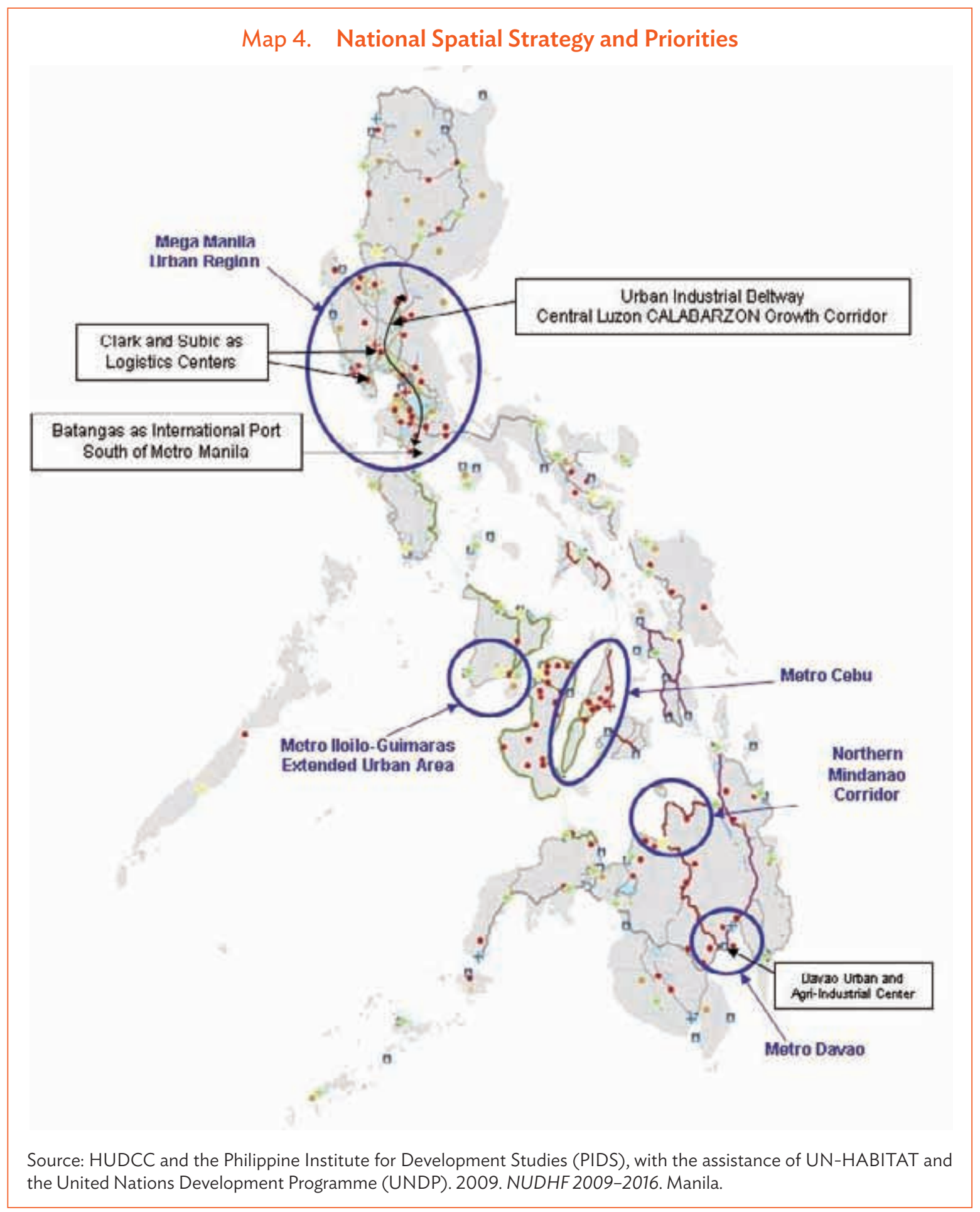




\section{Policy and Programming}

T

here are significant challenges in planning and implementing an urban sector program in the Philippines. Meeting these challenges will require the government to adopt and support multiple strategies, new initiatives, and innovative funding solutions. The key challenge for the government is the lack of institutional coordination among agencies. It is important that the implementing agencies, Housing and Urban Development Coordinating Council (HUDCC) and the Philippine Institute for Development Studies (PIDS) take ownership of the development process and outcomes to keep pace with the developments needs.

\section{Strategic Urban Infrastructure Investment Plan}

To facilitate implementation of projects in the urban sector, ADB will adopt two principal approaches: (i) the subsector approach, and (ii) the single-agency approach. ADB seeks to work with a single executing agency (not necessarily a single city) to facilitate implementation and develop long-term investment and capacity-building programs. Projects will be designed to support investments and capacity building involving a single subsector such as solid waste management (SWM) in more than one city. By concentrating on addressing the investment needs and associated policy, institutional, and regulatory reforms in a single subsector, cumulative local development impacts can contribute to long-term and sustainable results at the national level. This approach will be linked to the common strategic objective of supporting sustainable urban economic growth and development through the three core themes of urban competitiveness, sustainable communities, and performance-oriented governance.

ADB will continue to promote the establishment of integrated urban development plans for the provision of physical urban infrastructure. A multisector integrated approach should act as a catalyst to economic activity and ensure that growth is not impeded by infrastructure bottlenecks. These development plans should incorporate economic, inclusive, and green urban development components for all integrated urban sector development projects. They will provide a basis for targeting strategic investments in urban infrastructure, urban management and governance, capacity building, environmental services, and pro-poor development projects. In moving toward a performance-oriented government in the urban sector, it may be essential to set up a project governance mechanism such as a multisector steering committee or advisory group with representation from the various agencies involved in the project.

ADB is committed to support the urban sector in the Philippines; however, it is important that future program of $A D B$ investments in the urban sector is designed to avoid the previous shortcomings of assistance, and is well coordinated with other development agencies to avoid overlap and duplication. This rapid assessment of the urban sector has identified some key investment areas that the ADB could possibly target. The country partnership strategy (CPS), 2012-2016 results framework identified ADB priority areas for intervention aligned with government priorities. The additional priorities are outlined in italics under each of the three pillars to develop a 3E investment focus in the urban sector as detailed in Table 2. 


\section{Table 2. Suggested Areas for Interventions along the 3E Approach of ADB Urban Operational Plan}

\begin{tabular}{|c|c|c|c|c|}
\hline $\begin{array}{l}\text { ADB Sector Focus } \\
\text { (CPS): Government } \\
\text { Objectives }\end{array}$ & $\begin{array}{c}\text { Competitive Cities } \\
\text { Projects }\end{array}$ & $\begin{array}{l}\text { Green Cities } \\
\text { Projects }\end{array}$ & $\begin{array}{l}\text { Inclusive Cities } \\
\text { Projects }\end{array}$ & $\begin{array}{c}\text { ADB Indicative } \\
\text { Resource Allocation } \\
\text { in the Next Pipeline } \\
\text { and Thematic } \\
\text { Priorities }\end{array}$ \\
\hline $\begin{array}{l}\text { Transport (Strategy } \\
2020 \text { Core Area } \\
\text { 1- Infrastructure): } \\
\text { Increased and more } \\
\text { efficient movement } \\
\text { of goods and people, } \\
\text { including inter-island } \\
\text { connectivity }\end{array}$ & $\begin{array}{l}\text { National roads, } \\
\text { road safety, road } \\
\text { maintenance, road } \\
\text { freight, transport } \\
\text { policies and } \\
\text { reforms; sector- } \\
\text { wide management } \\
\text { and reforms } \\
\text { (governance), PPPs }\end{array}$ & $\begin{array}{l}\text { Urban public } \\
\text { transport; } \\
\text { environmental } \\
\text { concerns in the } \\
\text { transport sector; } \\
\text { multimodal transport } \\
\text { facilities; integrated } \\
\text { land use and } \\
\text { transport; sustainable } \\
\text { transport }\end{array}$ & $\begin{array}{l}\text { Affordable transport } \\
\text { options; NMT } \\
\text { options for flood } \\
\text { adaptation; sector- } \\
\text { wide management } \\
\text { and reforms } \\
\text { (governance) }\end{array}$ & $\begin{array}{l}\$ 262 \text { million, } 10 \% \\
\text { of total envelope, of } \\
\text { which: } \\
\text { GRO: } 100 \% \\
\text { GOV: } 100 \% \\
\text { CAD: } 100 \%\end{array}$ \\
\hline $\begin{array}{l}\text { Energy (Strategy } \\
2020 \text { Core Area } \\
\text { 1- Infrastructure; } \\
\text { Core Area 2- } \\
\text { Environment): } \\
\text { Reduced energy } \\
\text { consumption from } \\
\text { environmentally } \\
\text { unsustainable } \\
\text { energy sources and } \\
\text { improved energy } \\
\text { efficiency }\end{array}$ & $\begin{array}{l}\text { Energy sector } \\
\text { development }\end{array}$ & $\begin{array}{l}\text { Renewable energy; } \\
\text { energy efficiency and } \\
\text { conservation; } \\
\text { energy efficiency } \\
\text { in urban services; } \\
\text { energy-efficient } \\
\text { buildings; energy- } \\
\text { efficient technology }\end{array}$ & $\begin{array}{l}\text { Affordable energy; } \\
\text { rural electrification }\end{array}$ & $\begin{array}{l}\$ 200 \text { million, } 8 \% \text { of } \\
\text { total envelope, of } \\
\text { which: } \\
\text { GRO: } 100 \% \\
\text { ENV: } 100 \% \\
\text { CAD: } 100 \%\end{array}$ \\
\hline $\begin{array}{l}\text { Agriculture and } \\
\text { Natural Resources } \\
\text { (Strategy 2020 } \\
\text { Core Area 2- } \\
\text { Environment): } \\
\text { Ensured } \\
\text { management of } \\
\text { natural resources }\end{array}$ & $\begin{array}{l}\text { Land-based } \\
\text { natural resource } \\
\text { management; } \\
\text { water-based } \\
\text { natural resource } \\
\text { management; } \underline{\text { imit }} \\
\underline{\text { upland deforestation }} \\
\underline{\text { and soil erosion to }} \\
\underline{\text { reduce vulnerability to }} \\
\text { flash floods in urban } \\
\underline{\text { areas }}\end{array}$ & $\begin{array}{l}\text { Improve } \\
\text { conservation, } \\
\text { protection, } \\
\text { rehabilitation, and } \\
\text { management of } \\
\text { natural resources; } \\
\text { improve management } \\
\text { of the urban } \\
\text { watershed for } \\
\underline{\text { improved land and }} \\
\underline{\text { water management }} \\
\underline{\text { leading to sustainable }} \\
\underline{\text { urban ecosystems }}\end{array}$ & $\begin{array}{l}\text { Livelihood } \\
\text { opportunities in } \\
\text { natural-resource- } \\
\underline{\text { dependent }} \\
\text { communities; address } \\
\underline{\text { encroachment }} \\
\underline{\text { along riverbanks }} \\
\text { and fragile coastal } \\
\text { areas; appropriate } \\
\underline{\text { sewage disposal }} \\
\text { facilities, adequate } \\
\underline{\text { sewerage connections, }} \\
\underline{\text { and proper waste }} \\
\underline{\text { disposal to reduce }} \\
\underline{\text { environmental }} \\
\underline{\text { degradation of the }} \\
\text { country's waterways }\end{array}$ & $\begin{array}{l}\$ 275 \text { million, } 11 \% \text { of } \\
\text { total envelope, of } \\
\text { which: } \\
\text { GRO: } 33 \% \\
\text { SOC: } 33 \% \\
\text { GEN+EGM: } 67 \% \\
\text { GOV: } 33 \% \\
\text { ENV: } 100 \% \\
\text { CAD: } 67 \%\end{array}$ \\
\hline
\end{tabular}


Table 2 continued

\begin{tabular}{|c|c|c|c|c|}
\hline $\begin{array}{l}\text { ADB Sector Focus } \\
\text { (CPS): Government } \\
\text { Objectives }\end{array}$ & $\begin{array}{c}\text { Competitive Cities } \\
\text { Projects }\end{array}$ & $\begin{array}{l}\text { Green Cities } \\
\text { Projects }\end{array}$ & $\begin{array}{l}\text { Inclusive Cities } \\
\text { Projects }\end{array}$ & $\begin{array}{c}\text { ADB Indicative } \\
\text { Resource Allocation } \\
\text { in the Next Pipeline } \\
\text { and Thematic } \\
\text { Priorities }\end{array}$ \\
\hline $\begin{array}{l}\text { Water Supply and } \\
\text { Other Municipal } \\
\text { Infrastructure and } \\
\text { Services (Strategy } \\
2020 \text { Core Area } \\
\text { 2- Environment): } \\
\text { Improved access } \\
\text { of population to } \\
\text { water, sanitation, and } \\
\text { waste management } \\
\text { facilities }\end{array}$ & $\begin{array}{l}\text { Enhanced access } \\
\text { of population to } \\
\text { water, sanitation, and } \\
\text { waste management } \\
\text { facilities and services }\end{array}$ & $\begin{array}{l}\text { Conserving and } \\
\text { maintaining the } \\
\text { efficiency of existing } \\
\text { water supply } \\
\text { systems for ensuring } \\
\text { sustainability of water } \\
\text { sources; increasing } \\
\text { efficiency of urban } \\
\text { services; expand } \\
\text { sanitation coverage; } \\
\text { improve waste } \\
\text { management with } \\
\text { waste to energy and } \\
\text { reduce-reuse-recycle } \\
\text { principals }\end{array}$ & $\begin{array}{l}\text { Improved access } \\
\text { of population to } \\
\text { water, sanitation, and } \\
\text { waste management } \\
\text { facilities }\end{array}$ & $\begin{array}{l}\$ 190 \text { million, } 8 \% \text { of } \\
\text { total envelope, of } \\
\text { which: } \\
\text { GRO: } 37 \% \\
\text { SOC: } 63 \% \\
\text { GEN+EGM: } 100 \% \\
\text { ENV: } 100 \% \\
\text { CAD: } 37 \%\end{array}$ \\
\hline $\begin{array}{l}\text { Public Sector } \\
\text { Management } \\
\text { (Strategy } 2020 \\
\text { Driver of Change): } \\
\text { Improved availability } \\
\text { and more efficient } \\
\text { use of public finances }\end{array}$ & $\begin{array}{l}\text { Policy and strategy } \\
\text { formulation, reforms } \\
\text { and restructuring, } \\
\text { macroeconomic } \\
\text { management; } \\
\text { improved investment } \\
\text { climate and private } \\
\text { sector development; } \\
\text { improved } \\
\text { decentralization and } \\
\text { local governance; } \\
\text { increased real } \\
\text { property tax } \\
\text { collections }\end{array}$ & $\begin{array}{l}\text { Public expenditure } \\
\text { and fiscal } \\
\text { management, } \\
\text { revenue mobilization; } \\
\text { accounting and } \\
\text { auditing; legal and } \\
\text { judiciary reforms; aid } \\
\text { effectiveness and } \\
\text { aid coordination; } \\
\text { cost recovery tariffs; } \\
\text { performance- } \\
\text { based transfers; } \\
\text { metropolitan } \\
\text { governance }\end{array}$ & $\begin{array}{l}\text { Civil society } \\
\text { participation in } \\
\text { national affairs; } \\
\text { decentralization and } \\
\text { devolution; improved } \\
\text { stakeholder } \\
\text { participation }\end{array}$ & $\begin{array}{l}\$ 1.2 \text { billion, } 48 \% \text { of } \\
\text { total CPS envelope, } \\
\text { of which: } \\
\text { GRO: } 75 \% \\
\text { GEN+EGM: } 83 \% \\
\text { GOV: } 42 \% \\
\text { PSD: } 58 \% \\
\text { CAD: } 100 \%\end{array}$ \\
\hline
\end{tabular}

$\mathrm{ADB}=$ Asian Development Bank, CAD = capacity development, CPS = country partnership strategy, CSO = civil society organization, $\mathrm{EGM}=$ effective gender mainstreaming, $\mathrm{ENV}=$ environmental sustainability, $\mathrm{GDP}=$ gross domestic product, $\mathrm{GEN}$ = gender equity, GOV = governance, $\mathrm{GRO}=$ economic growth, $\mathrm{km}=$ kilometer, $\mathrm{LGU}=$ local government unit, $\mathrm{PPP}=$ public-private partnership, $\mathrm{PSD}=$ private sector development, $\mathrm{SOC}=$ social development.

Note: The resource envelope reflected in the results framework accounts for $97 \%$ of the $2011-2014$ resource envelope. The remainder is a disaster risk finance loan, which contributes to Strategy 2020 Core Area 2 (environment).

Source: Author's analysis based on ADB. 2011b. Country Partnership Strategy: Philippines, 2011-2016. Manila. 


\section{E Targeted Investment Program}

$\mathrm{T}$ he urban sector will require a total investment of approximately $\$ 42$ billion in constant 2008 prices over the next 18 years to address deficiencies in the delivery of basic services and to expand existing facilities. Of the total, $\$ 14$ billion will be required to satisfy the existing shortfalls in the delivery of basic urban services: $\$ 27.9$ billion will be required to construct new infrastructure facilities and to expand existing networks.

\section{Urban Projects Formulated Based on 3E Assessment}

The $3 E$ framework provides the platform for ADB to leverage the drivers for developing cities and to apply these to highlighted urban priorities. Cities must become more competitive, inclusive, and environmentally responsive if they are to become more economically dynamic and liveable places. Incorporating the current sectors of focus in the country partnership strategy (CPS) - transport, energy, water supply and municipal services, and public sector management-the following table outlines an agenda for the appropriate investment of ADB funding into its urban priority locations.

\section{Table 3. 3E Targeted Investment Priorities by Sector}

\begin{tabular}{|c|c|c|c|}
\hline $\begin{array}{l}\text { ADB Sector } \\
\text { Focus }\end{array}$ & Green Cities & Competitive Cities & Inclusive Cities \\
\hline $\begin{array}{l}\text { Urban } \\
\text { Development }\end{array}$ & $\begin{array}{l}\text { Policy-From acts to } \\
\text { action: operationalize } \\
\text { the environmental acts; } \\
\text { target investment in urban } \\
\text { environmental infrastructure } \\
\text { for climate change adaptation } \\
\text { and mitigation. }\end{array}$ & $\begin{array}{l}\text { Policy-Peri-urbanization } \\
\text { of smaller towns and cities } \\
\text { near major growth centers to } \\
\text { stimulate economic growth } \\
\text { to further capture benefits of } \\
\text { urbanization. } \\
\text { Institutions and regulatory } \\
\text { systems } \\
\text { - diversify export-oriented } \\
\text { manufacturing and support } \\
\text { development of robust } \\
\text { industry sector to create } \\
\text { more productive job } \\
\text { opportunities for unskilled } \\
\text { labor. Provide vocational } \\
\text { education; } \\
\text { - enhance local outlets for } \\
\text { credit finance Investment } \\
\text { in small and medium- } \\
\text { sized enterprise (SME) } \\
\text { promotion through } \\
\text { industry associations and } \\
\text { e-governance to reduce } \\
\text { transaction costs and } \\
\text { support SME development. }\end{array}$ & $\begin{array}{l}\text { Policy-Provision of } \\
\text { incentives to promote growth } \\
\text { in regional centers and } \\
\text { address regional disparities, } \\
\text { urban imbalance and } \\
\text { migration, given the limited } \\
\text { absorptive capacity of major } \\
\text { urban areas. } \\
\text { Human resource } \\
\text { development } \\
\text { - link education, } \\
\text { vocational training, and } \\
\text { skills development to } \\
\text { employment creation; } \\
\text { - develop vocational } \\
\text { education and supply chain } \\
\text { capacity; } \\
\text { - undertake local revenue- } \\
\text { generating activities }\end{array}$ \\
\hline
\end{tabular}


Table 3 continued

\begin{tabular}{|c|c|c|c|}
\hline $\begin{array}{l}\text { ADB Sector } \\
\text { Focus }\end{array}$ & Green Cities & Competitive Cities & Inclusive Cities \\
\hline Land Management & $\begin{array}{l}\text { - address urban renewal } \\
\text { through targeted } \\
\text { investments for } \\
\text { rehabilitation of low- } \\
\text { income communities in } \\
\text { environmentally precarious } \\
\text { urban areas; } \\
\text { - review of land-use and land } \\
\text { conversion policies; } \\
\text { - establish transparent and } \\
\text { accountable systems that } \\
\text { enable organizational } \\
\text { reform to bring in good } \\
\text { governance in the real } \\
\text { estate market. }\end{array}$ & $\begin{array}{l}\text { - consolidation of data on } \\
\text { urban land use; } \\
\text { - development of a } \\
\text { centralized land-use } \\
\text { database system with GIS } \\
\text { mapping (on the highest } \\
\text { best use basis) can aid } \\
\text { government in tapping } \\
\text { land value and will increase } \\
\text { efficiency in property tax } \\
\text { collection; } \\
\text { - establishment of risk- } \\
\text { sensitive land-use } \\
\text { management; } \\
\text { - ensure protection of rights } \\
\text { and promote compliance of } \\
\text { regulations by all agencies, } \\
\text { including private sector, } \\
\text { responsible for delivery of } \\
\text { housing in an otherwise } \\
\text { inefficient land and housing } \\
\text { market; } \\
\text { - address housing } \\
\text { affordability. }\end{array}$ & $\begin{array}{l}\text { - empower communities to } \\
\text { increase accountability and } \\
\text { transparency in monitoring } \\
\text { and implementation of } \\
\text { upgrading strategies for } \\
\text { poor urban communities. }\end{array}$ \\
\hline $\begin{array}{l}\text { Solid Waste } \\
\text { Management }\end{array}$ & $\begin{array}{l}\text { - From acts to action- } \\
\text { operationalize the } \\
\text { environmental acts and } \\
\text { tighten implementation. }\end{array}$ & $\begin{array}{l}\text { - increase efficiency in waste } \\
\text { management; } \\
\text { - exploit cross-sector } \\
\text { synergies such as waste to } \\
\text { energy options. }\end{array}$ & $\begin{array}{l}\text { - improve access of urban } \\
\text { population to adequate } \\
\text { solid waste disposal. }\end{array}$ \\
\hline $\begin{array}{l}\text { Water Supply and } \\
\text { Municipal Services }\end{array}$ & $\begin{array}{l}\text { - undertake water recycling } \\
\text { and waste recovery; } \\
\text { - develop a watershed plan } \\
\text { with a combination of } \\
\text { restoration and protection } \\
\text { measures, as a superset of } \\
\text { the land use plan. }\end{array}$ & $\begin{array}{l}\text { - undertake local revenue- } \\
\text { generating activities; } \\
\text { - support infrastructure-led } \\
\text { development. }\end{array}$ & $\begin{array}{l}\text { - improve access of urban } \\
\text { population to piped water } \\
\text { on premises. }\end{array}$ \\
\hline $\begin{array}{l}\text { Transport and } \\
\text { Tourism }\end{array}$ & $\begin{array}{l}\text { - pursue strategic } \\
\text { investments in cross- } \\
\text { sector initiatives such } \\
\text { as health tourism, and } \\
\text { cultural tourism alongside } \\
\text { alternative livelihood } \\
\text { opportunities for natural- } \\
\text { resource-dependent } \\
\text { communities; } \\
\text { - public transport, land-use/ } \\
\text { transport synergies; } \\
\text { - reduce greenhouse gas } \\
\text { (GHG) emission in power } \\
\text { and transport sectors; }\end{array}$ & $\begin{array}{l}\text { - invest in transport and } \\
\text { tourism infrastructure } \\
\text { to improve access and } \\
\text { economic prospects of } \\
\text { geographically dispersed } \\
\text { regions; } \\
\text { - measure and reduce } \\
\text { infrastructure bottlenecks; } \\
\text { - manage increasing densities } \\
\text { and growth among } \\
\text { corridors. }\end{array}$ & $\begin{array}{l}\text { - pursue strategic } \\
\text { investments in cross- } \\
\text { sector initiatives such } \\
\text { as health tourism, and } \\
\text { cultural tourism alongside } \\
\text { alternative livelihood } \\
\text { opportunities for natural- } \\
\text { resource-dependent } \\
\text { communities. }\end{array}$ \\
\hline
\end{tabular}


Table 3 continued

\begin{tabular}{|c|c|c|c|}
\hline $\begin{array}{l}\text { ADB Sector } \\
\text { Focus }\end{array}$ & Green Cities & Competitive Cities & Inclusive Cities \\
\hline & $\begin{array}{l}\text { - new transport technologies } \\
\text { like e-jeepneys can mitigate } \\
\text { transport emissions. }\end{array}$ & & \\
\hline Energy & $\begin{array}{l}\text { - addressing climate change; } \\
\text { - mitigating GHG emissions; } \\
\text { - increase energy efficiency in } \\
\text { urban services; } \\
\text { - planning energy-efficient } \\
\text { building construction; } \\
\text { - investing in clean } \\
\text { production technology; }\end{array}$ & $\begin{array}{l}\text { - reliable and secure } \\
\text { electricity services at } \\
\text { competitive rates are } \\
\text { essential to improving the } \\
\text { investment climate. }\end{array}$ & $\begin{array}{l}\text { - provision of affordable } \\
\text { electricity; } \\
\text { - rural electrification; } \\
\text { - renewable energy } \\
\text { for community-led } \\
\text { development. }\end{array}$ \\
\hline $\begin{array}{l}\text { Urban Governance } \\
\text { and Public Sector } \\
\text { Management }\end{array}$ & $\begin{array}{l}\text { - establish governance } \\
\text { mechanisms for } \\
\text { coordination of planning } \\
\text { and implementation of } \\
\text { projects; } \\
\text { - form a unitary national } \\
\text { agency with a strong } \\
\text { mandate for urban } \\
\text { development; } \\
\text { - establish green building } \\
\text { codes and certification. }\end{array}$ & $\begin{array}{l}\text { - strengthen tax collection to } \\
\text { ensure adequate resources } \\
\text { for social and physical } \\
\text { infrastructure development } \\
\text { and as a requisite to } \\
\text { sustainable economic } \\
\text { growth; } \\
\text { - strengthen property rights; } \\
\text { - promote private-public } \\
\text { partnerships; } \\
\text { - improving the domestic } \\
\text { investment climate to } \\
\text { encourage the domestic } \\
\text { banking sector and the } \\
\text { private sector to invest in } \\
\text { infrastructure is crucial } \\
\text { to attaining long-term } \\
\text { development goals; } \\
\text { - regional planning and } \\
\text { coordination; } \\
\text { - innovative financing } \\
\text { alternatives; } \\
\text { - capacity development of } \\
\text { local government units } \\
\text { (LGUs) for technical and } \\
\text { management skills }\end{array}$ & $\begin{array}{l}\text { - addressing project } \\
\text { partnerships; } \\
\text { - reforming local government } \\
\text { institutions; } \\
\text { - encouraging microfinance; } \\
\text { - climate change and } \\
\text { adaptation; } \\
\text { - asset management } \\
\text { and community-based } \\
\text { budgeting; } \\
\text { - effective transparency and } \\
\text { accountability mechanisms } \\
\text { important at national and } \\
\text { local levels. }\end{array}$ \\
\hline
\end{tabular}

Source: Author's analysis. 


\section{Appendix}

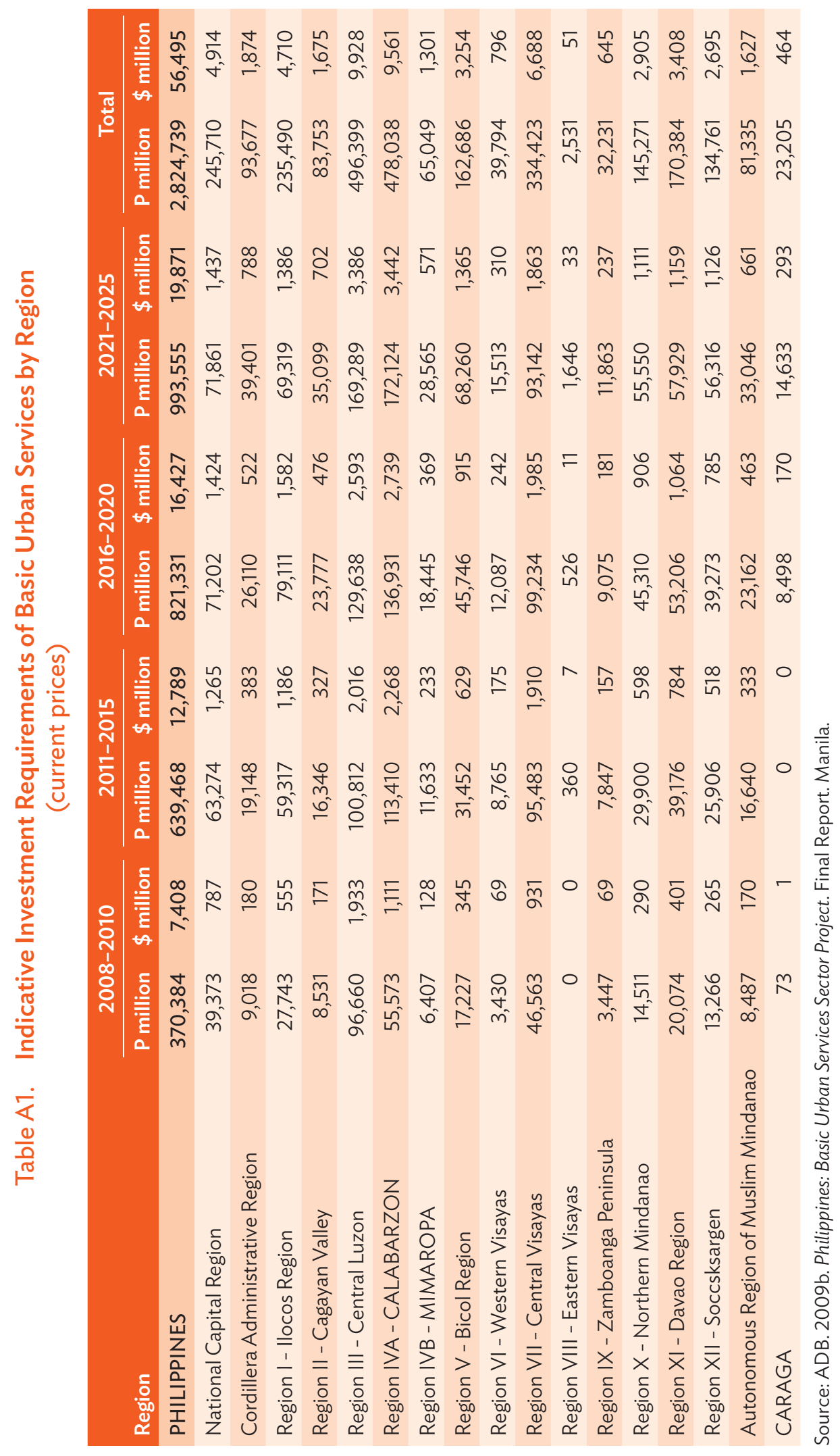




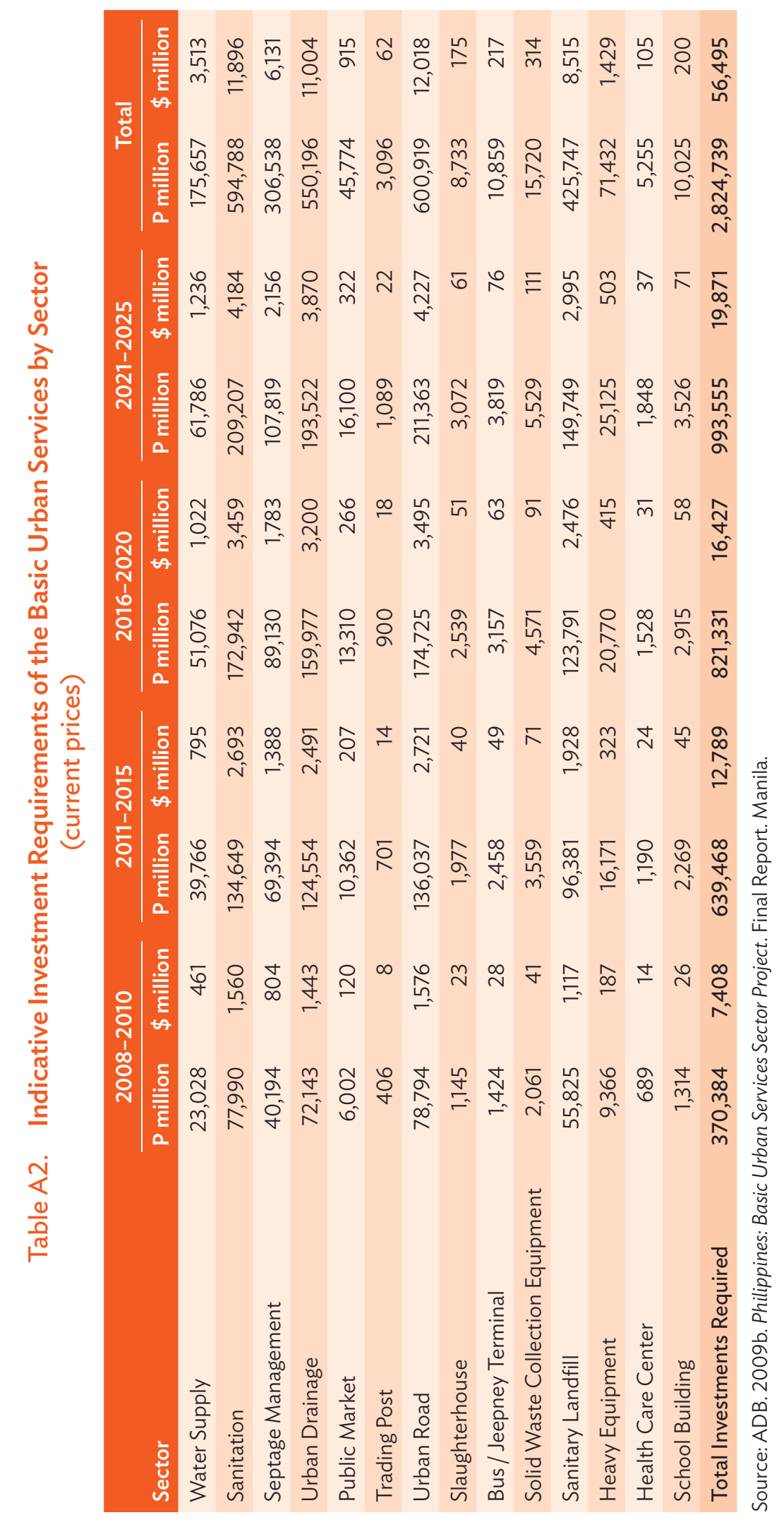


Table A3. Proposed Financing Plan

(constant 2008 prices)

\begin{tabular}{|c|c|c|c|c|}
\hline \multirow[b]{2}{*}{ Particulars } & \multirow{2}{*}{$\begin{array}{l}\text { Committed } \\
\text { Funds } \\
\text { (5-10 years) }\end{array}$} & \multirow{2}{*}{$\begin{array}{l}\text { Balance of } \\
\text { Financing } \\
\text { Requirement }\end{array}$} & \multicolumn{2}{|c|}{ Total } \\
\hline & & & Amount & $\%$ share \\
\hline \multicolumn{5}{|c|}{ National Government } \\
\hline P million & 219,346 & 305,365 & 524,711 & \multirow{2}{*}{25} \\
\hline$\$$ million & 4,387 & 6,107 & 10,494 & \\
\hline \multicolumn{5}{|c|}{ GFls / GOCCs } \\
\hline P million & 105,407 & 209,420 & 314,827 & \multirow{2}{*}{15} \\
\hline$\$$ million & 2,108 & 4,188 & 6,297 & \\
\hline \multicolumn{5}{|l|}{ PFls } \\
\hline P million & 56,540 & 153,344 & 209,884 & \multirow{2}{*}{10} \\
\hline$\$$ million & 1,131 & 3,067 & 4,198 & \\
\hline \multicolumn{5}{|l|}{ LGUs } \\
\hline P million & 132,873 & 77,011 & 209,884 & \multirow{2}{*}{10} \\
\hline$\$$ million & 2,657 & 1,540 & 4,198 & \\
\hline \multicolumn{5}{|l|}{ Donors } \\
\hline P million & 11,276 & 408,493 & 419,769 & \multirow{2}{*}{20} \\
\hline$\$$ million & 226 & 8,170 & 8,395 & \\
\hline \multicolumn{5}{|l|}{ MDFO } \\
\hline P million & 14,135 & 90,807 & 104,942 & \multirow{2}{*}{5} \\
\hline$\$$ million & 283 & 1,816 & 2,099 & \\
\hline \multicolumn{5}{|c|}{ Private Sector } \\
\hline P million & - & 314,827 & 314,827 & \multirow{2}{*}{15} \\
\hline \$ million & - & 6,297 & 6,297 & \\
\hline \multicolumn{5}{|l|}{ Total } \\
\hline P million & 539,577 & $1,559,267$ & $2,098,844$ & \multirow{2}{*}{100} \\
\hline$\$$ million & 10,792 & 31,185 & 41,977 & \\
\hline
\end{tabular}

GFI = government financing institution, $\mathrm{GOCC}$ = government-owned and controlled corporation, LGU = local government unit, MDFO = Municipal Development Fund Office, PFI = private financing institution. Source: ADB. 2009b. Philippines: Basic Urban Services Sector Project. Final Report. Manila. 


\section{References}

Asian Development Bank (ADB). 2001. Development of Poor Urban Communities Project. Final Report. Manila.

2003. Local Government Finance and Bond Markets. (Chapter on Philippines, Lydia N. Orial). Manila.

2004. City Development Strategy. In Asian Development Bank. 31 May. http://www.adb.org/Documents/Books/City_Devt_Strategies/citydevt.pdf.

2006. Special Evaluation Study on Urban Sector Strategy and Operations. Manila.

2008a. Managing the Cities in Asia: Philippines Case Study. Manila. 2008b. Managing Asian Cities. Manila.

2009a. Institutional Strengthening of Housing and Urban Development Sector. Final Report. Manila. .2009b. Philippines: Basic Urban Services Sector Project. Final Report. Manila. .2009c. Poverty in the Philippines: Causes, Constraints, and Opportunities. Manila.

2010a. Methodology for Estimating Carbon Footprint of Road Projects-Case Study: India. Manila.

2010b. Philippines: Urban Sector Assessment Roadmap 2010. Southeast Asia Department Working Paper. Manila.

2011a. Manual for National Urban Assessments. Manila.

2011b. Country Partnership Strategy: Philippines, 2011-2016. Manila.

2011c. Key Indicators 2011: World Urbanization Prospects. Manila.

2011d. Draft Urban Operational Plan Strategy. Manila.

2011e. Asia 2050: Realizing the Asian Century. Manila.

.2011f. Tool Kit for Public-Private Partnerships in Urban Bus Transport for the State of Maharashtra, India. Manila.

2011g. Walkability and Pedestrian Facilities in Asian Cities State and Issues. Sustainable Development Working Papers. Manila.

.2011h. Thematic Assessment (Summary): Good Governance and Political Economy. Country Partnership Strategy: Philippines, 2011-2016. Manila. 
2011i. Thematic Assessment: Climate Change and Disaster Risk Reduction.

Country Partnership Strategy: Philippines, 2011-2016. Manila.

2011j. Thematic Assessment (Summary): Water Supply and Other Municipal Infrastructure and Services. Country Partnership Strategy: Philippines, 20112016. Manila.

2011k. Thematic Assessment: Poverty. Country Partnership Strategy: Philippines, 2011-2016. Manila.

20111. Thematic Assessment (Summary): Energy. Country Partnership Strategy: Philippines, 2011-2016. Manila.

2011m. Prospects for the Philippines. Speech delivered by V.P. Groff to the Foreign Correspondents Association, 19 January, Manila.

.2012a. Philippines: Water Supply and Sanitation Sector Assessment, Strategy, and Road Map. Manila.

2012b. Country Operations Business Plan: Philippines, 2013-2015. Manila.

2012c. Confronting Rising Inequality in Asia. Asian Development Outlook 2012. Manila. http://www.adb.org/sites/default/files/ado2012-phi.pdf

2012d. Philippines: Water Supply and Sanitation Sector Assessment, Strategy, and Road Map. Manila.

2014. Philippines Fact Sheet. Manila http://www.adb.org/sites/default/files/ pub/2014/PHI.pdf

ADB and the Government of Australia. 2011. Competitive Cities in the 21st Century: Cluster-Based Local Economic Development Revealed: The Philippines. Manila: ADB.

Bureau of the Treasury. 2013. National Government Debt Remains Sustainable as of end-June 2013. Press release. 29 August. http://www.treasury.gov.ph/news/ news/NGDebtJune2013-press\%20release\%20revised.pdf

Camagni, R. 1998. Sustainable Urban Development: Definition and Reasons for a Research Programme. International Journal of Environment and Pollution. 10 (1). pp. 6-27.

Camagni, R., R. Capello, and P. Nijkamp. 1998. Towards Sustainable City Policy: An Economy Environment Technology Nexus. Ecological Economics. 24 (1). pp. 103-118.

Castro, Jun. 2012. Role of the UP School of Urban and Regional Planning in the Certification of Urban Planners in the Philippines: Prospects, Issues and Constraints. Quezon City: UP SURP. https://eascongress.pemsea.org/sites/ default/files/document-files/presentation-st52-castro.pdf

Cheshire, P. and I.R. Gordon, eds. 1995. Territorial Competition in an Integrated Europe. Aldershot: Avebury. 
Cheshire, P. and I.R. Gordon. 1996. Territorial Competition and the Predictability of Collective (In) Action. International Journal of Urban and Regional Research. 23 (3). pp. 383-399.

Choe, K. and A. Laquian. 2008. City Cluster Development: Toward an Urban-Led Development Strategy for Asia. Manila: Asian Development Bank.

Cities Alliance. 2011. City Development Strategy. http://www.citiesalliance.org/ca/ about-cds

Cities Development Initiatiative for Asia (CDIA). 2010. City Infrastructure Investment Programming \& Prioritisation Toolkit (CIIPP). In Cities Development Initiative for Asia. http://cdia.asia/wp-content/uploads/User-Manual-Generic -version-2010.pdf

2011. Project Overview. http://www.cdia.asia/wp-content/uploads/gravity_ forms/41/2011/09/PO-Philippines-Naga-new.pdf

2012. Pre-Feasibility Study Guidelines. Manila, Philippines. www.cdia.asia

Co, E.E., R.L. Fernan, and F. Sta. Ana. 2007. Philippine Democracy Assessment: Economic and Social Rights. State of Democracy. Manila: Anvil Publishing.

Department of Budget and Management, Republic of the Philippines. 2012. Internal Revenue Allotment. http://www.dbm.gov.ph/ira.php

Department of Environment and Natural Resources (DENR). 2010. www.denr.gov.ph

Housing and Urban Development Coordinating Council (HUDCC). 2009. National Urban Development and Housing Framework (NUDHF) 2009-2016. Manila.

Housing and Urban Development Coordinating Council (HUDCC) and Philippine Institute for Development Studies (PIDS). 2009. NUDHF 2009-2016. Manila: UN-HABITAT and United Nations Development Programme (UNDP).

Interaksyon. 2012. PH Electricity Rates among 10 Highest in Survey of 44 Countries. http://www.interaksyon.com/business/40664/ph-electricity-rates-among10-highest-in-survey-of-44-countries

International Energy Consultants. 2012. Regional Comparison of Retail Electricity Tariffs. Meralco. Manila.

Kelly, P. 1998. The Politics of Urban-Rural Relations: Land Use Conversion in the Philippines. Environment and Urbanization. 10 (1). 35 pp.

Manabat Sanaugustin \& Co. CPAs and KPMG 2011. The Philippines-Outsourcing's new destination. A Guide for Businessmen and Investors. http://www.kpmg .com/PH/en/PHConnect/ArticlesAndPublications/Documents/The\%20 Philippines-\%200utsourcing's\%20new\%20destination--\%20Guide\%20 for\%20Businessmen\%20and\%20Investors\%202011-2012\%20Digital\%20 Edition.pdf

Maniego, P. and L. Weischer. 2011. The Right Mix: The Philippines Achieving its Renewable Energy Goals. http://insights.wri.org/news/2011/07/right-mix -philippines-achieving-its-renewable-energy-goals 
Manila Observatory for the Congressional Commission on Science \& Technology and Engineering. 2010. Technical Primer on Climate Change. Manila.

McKeown, R. 2002. The Education for Sustainable Development Toolkit. http:// www.esdtoolkit.org/esd_toolkit_v2.pdf

McKinsey Global Institute. 2009. Preparing for [the People's Republic of] China's Urban Billion - Impacts of Urbanization: Implications for Urban Infrastructure. New York: McKinsey \& Company.

2010. India's Urban Awakening. Building Inclusive Cities, Sustaining Economic Growth. Mumbai: McKinsey \& Company.

Naik-Singru, R. 2008. Democracy, Competitive Governance \& Spatial Transformation in 'Globalising' Mumbai. First ISA Forum of Sociology, 5-8 September, Barcelona, Spain.

National Economic and Development Authority (NEDA). 2002. National Framework for Physical Planning: 2001-2030. Mandaluyong City.

National Solid Waste Management Commission. 2012. Manila. http://www.emb .gov.ph/portal/nswmc/NSWMC.aspx

National Statistical Coordination Board. 2011. Summary of StatDev 2011 Indicators by Sector and by Pace of Performance. http://www.nscb.gov.ph/stats/ statdev/2011/Accelerating_infra/Chapter_accelerating_infra.asp (accessed July 2012).

National Statistics Office (NSO). 2010. Philippine Statistical Yearbook. Manila.

2012. Provincial Summary, Number of Provinces, Cities, Municipalities and Barangays, by Region as of 31 March 2012. Manila.

Philippine Commission on Population. 2004. State of the Philippine Population Report. Manila.

Republic of the Philippines. 2007. Philippine Sustainable Sanitation Roadmap. Manila. 2008. Supreme Court Decision. G.R. Nos. 171947-48. 18 December. http:// www.pemsea.org/sites/default/files/manilabay-supremecourt-decision.pdf

Siemens AG. 2011. Asian Green City Index. Munich.

Singh, K., F. Steinberg, and N. Einsiedel von, eds. 1996. Integrated Urban Infrastructure Development in Asia. Oxford: Oxford Publishing.

United Nations, Department of Economic and Social Affairs, Population Division. 2008. World Urbanization Prospects: The 2007 Revision. New York.

2012. World Urbanization Prospects: The 2011 Revision. New York.

UN-Habitat. 2008. Urban Info.

UN-Habitat. 2011. Cities and Climate Change-Global Report on Human Settlements. Nairobi: UN-Habitat. 
1986. UN-Habitat Urban Management Programme. http://www.unhabitat .org/content.asp? typeid $=19 \&$ catid $=374 \&$ cid $=188$

URBACT. 2011. http://urbact.eu/en/header-main/integrated-urban development/ understandingintegrated-urban-development/

Westfall, M. and V. De Villa, eds. 2001. Urban Indicators for Managing Cities. Manila: Asian Development Bank.

World Bank. 2004. A Framework for Sustainable Philippine Archipelagic Development (ArcDev). Manila: Department of Environment and Natural Resources.

2005. East Asian Urbanization: Objectives, Policies and Programs. Manila, Philippines.

2007a. Philippines Environment Monitor 2006. Washington, DC.

2007b. Tools for Institutional, Political and Social Analysis of Policy Reform.

Washington, DC: International Bank for Reconstruction and Development/ The World Bank.

2010. A Strategic Approach to Climate Change in the Philippines. Final Report. Washington, DC.

2011a. Data on Urban Development. http://data.worldbank.org/topic/urban -development (accessed 31 October 2011).

.2011b. Doing Business Report 2012. http://www.doingbusiness.org/Reforms/ Overview/Economy/Philippines

2011c. Executive Summary. In Philippines - Typhoons Ondoy and Pepeng: Post-Disaster Needs Assessment. Vol. I. Washington, DC. http://documents. worldbank.org/curated/en/2011/01/15115760/philippines-typhoons-ondoy -pepeng-post-disaster-needs-assessment-vol-1-3-executive-summary

World Commission on Environment and Development (WCED). 2008. Our Common Future. Oxford: Oxford University Press.

World Economic Forum. 2012. Global Competitiveness Index Report, 2012-2013. Geneva, Switzerland.

World Resources Institute and Government of the Philippines. 2007. Philippine Water Supply Sector Roadmap. Manila. 


\section{Republic of the Philippines National Urban Assessment}

The Urban Operational Plan (UOP) 2012-2020 of the Asian Development Bank (ADB) supports ADB developing member countries (DMCs) in expanding their urban economies, improving environmental sustainability, and making pro-poor investments through a $3 \mathrm{E}$ approach (Economy, Environment, and Equity). This case study on the Philippines is based on thematic areas of the National Urban Sustainability Assessment framework for developing strategic policy options and targeted investments in the urban sector. This publication shows how the framework acts as a tool for conducting rapid urban assessments at both national and urban region levels for DMCs.

\section{About the Asian Development Bank}

ADB's vision is an Asia and Pacific region free of poverty. Its mission is to help its developing member countries reduce poverty and improve the quality of life of their people. Despite the region's many successes, it remains home to approximately two-thirds of the world's poor: 1.6 billion people who live on less than $\$ 2$ a day, with 733 million struggling on less than $\$ 1.25$ a day. $A D B$ is committed to reducing poverty through inclusive economic growth, environmentally sustainable growth, and regional integration.

Based in Manila, ADB is owned by 67 members, including 48 from the region. Its main instruments for helping its developing member countries are policy dialogue, loans, equity investments, guarantees, grants, and technical assistance. 